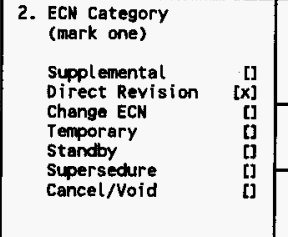

3. Originator's Name, Organization, MSIN, and Telephone No.

J. G. Field, Evaluation and

Planning, R2-12, 376-3753

6. Project Title/No./Hork Order No.

AP-103 TCR

9. Document Numbers Changed by this ECN (includes sheet no. and rov.) WHC-SD-WM-ER-359, Rev. 0

12a. Modification Work

[] Yes cfill out Btk. 12b)

[X] No (HA Blks. 12b, $12 c, 12 d)$

12b. Work Package 12c. Modification Hork Complete No.

$$
\text { N I A }
$$

$N \mid A$

Design Authority/Cog. Engineer Signature \& Date

13a. Description of Change 13b. Design Basel ine Document?

Revised to new format per DOE performance agreements

\begin{tabular}{|l|l|}
\hline $\begin{array}{l}\text { 4. USQ Required? } \\
{[] \text { Yes }[X] \text { No }}\end{array}$ & $\begin{array}{l}5 . \text { Date } \\
1 / 16 / 97\end{array}$ \\
\hline $\begin{array}{l}\text { 7. Bldg./Sys./Fac. No. } \\
\text { EDT Approyal Designator } \\
\mathrm{N} / 4\end{array}$ \\
\hline EDT 608044
\end{tabular}

EDT 608044

tion (Testored to Original Condi tion (Temp. or Standby ECN only)

\title{
$N$ la
}

Design Authority/Cog. Engineer Signoture \& Date

[x] No

[] Yes

[x] No

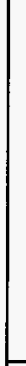

14a. Justification (mark one)

Criteria Change

As-found

[] $\mathrm{x}]$

Design Improvement

Facilitate Const

[] Enviromental

[]

Const . Error/Onission

[]

Facility Deactivation Design Error/Omission

14b. Justification Details

Revised per DOE performance agreement and direction from the Washington State

Department of Ecology to revise 23 TCR's (letter dated 7/6/1995).

15. Distribution (include name, MSIN, and no. of copies)

Attached 


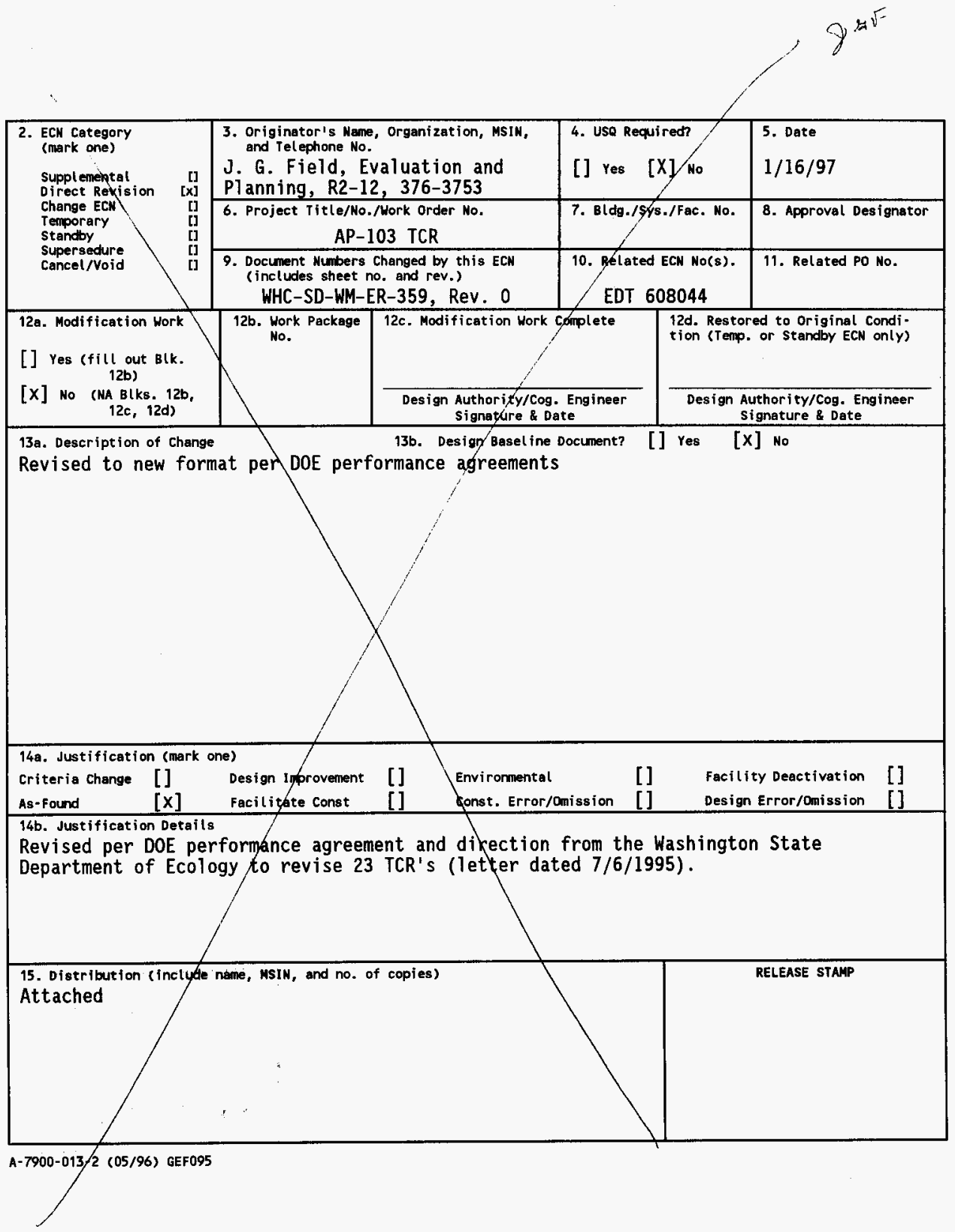




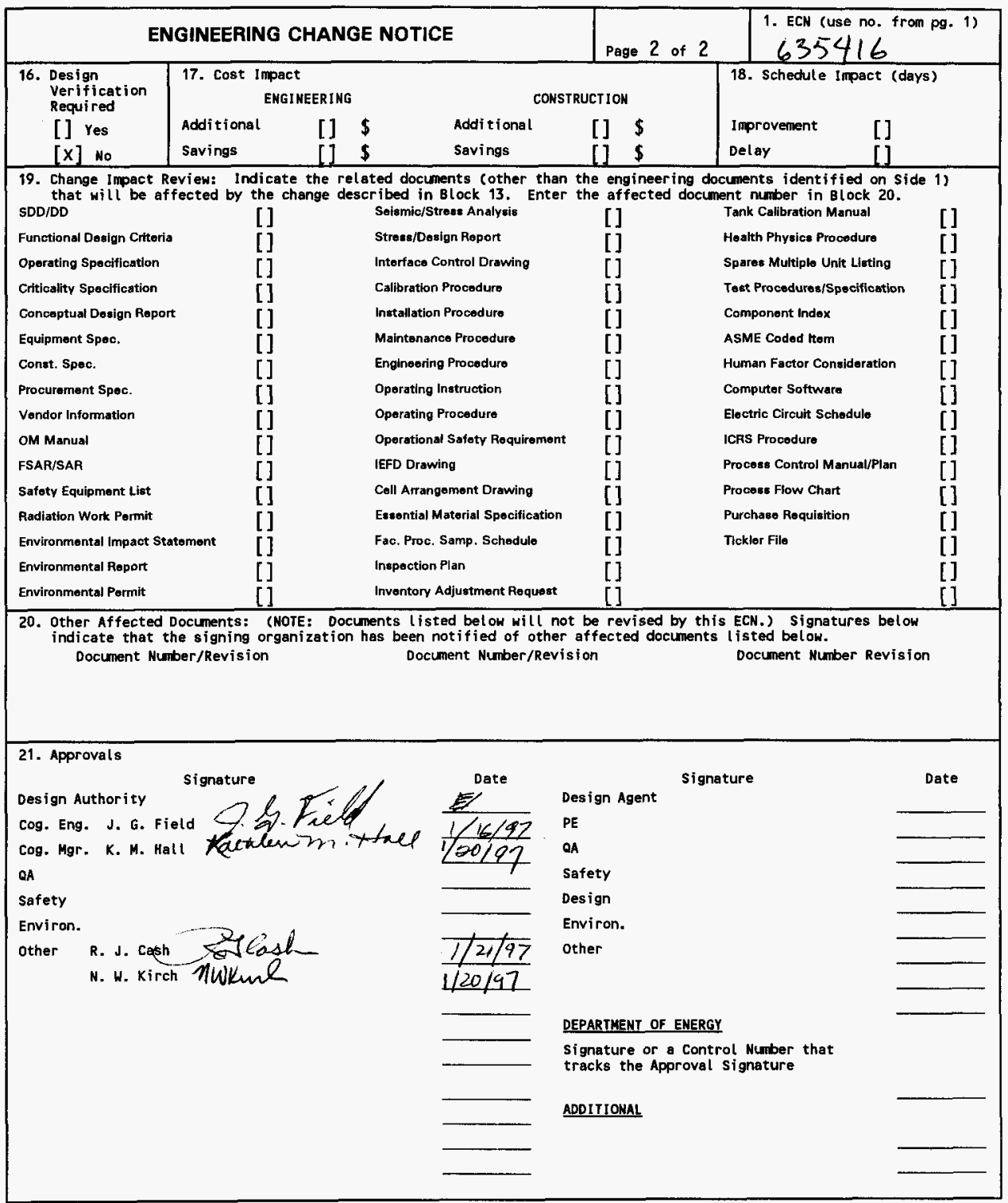




\section{THIS

$$
\begin{aligned}
& \text { AGE INTENTIONALLY } \\
& \text { LEFT BLANK }
\end{aligned}
$$




\title{
Tank Characterization Report for Double-Shell Tank 241-AP-103
}

\author{
J. G. Field \\ Lockheed Martin Hanford Company, Richland, WA 99352 \\ U.S. Department of Energy Contract DE-AC06-87RL10930
}

$\begin{array}{ll}\text { EDT/ECN: } 635416 & \text { UC: } 2070 \\ \text { Org Code: } 74610 & \text { Charge Code: } \\ \text { B\&R Code: EW3120074 } & \text { Total Pages: } 116\end{array}$

Key Words: Tank 241-AP-103, AP-103, AP Farm, Tank Characterization Report, TCR, Double-She11 Tank, Waste Characterization, Waste Inventory, TPA Milestone M-44

Abstract: This document summarizes information on historical uses, present status, and the sampling and analysis results of waste stored in Tank 241-AP-103, Sampling and Analyses Meet Safety Screening Objectives. This report supports requirements of Tri-Party Agreement Milestone M-44-05.

TRADEMARK DISCLAIMER. Reference herein to any specific commercial product, process, or service by trade name, trademark, manufacturer, or otherwise, does not necessarily constitute or inply its endorsement, recommendation, or favoring by the United states Government or any agency thereof or its contractors or subcontractors.

Printed in the United States of America. To obtain copies of this document, contact: WHC/BCS Document Control Services, P.O. Box 1970, Mailstop H6-08, Richland WA 99352, Phone (509) 372-2420; Fax (509) 376-4989.
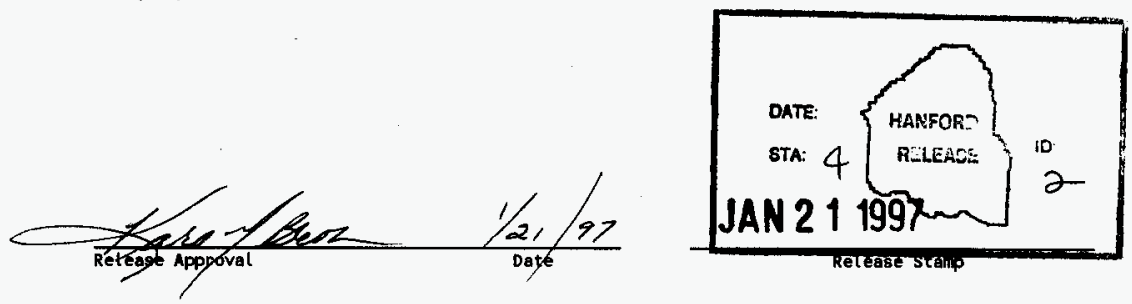

Approved for Public Release 
THIS PAGE INTENTIONALLY LEFT BLANK 
(2) Title

Tank Characterization Report for Double-She11 Tank 241-AP-103

CHANGE CONTROL RECORO

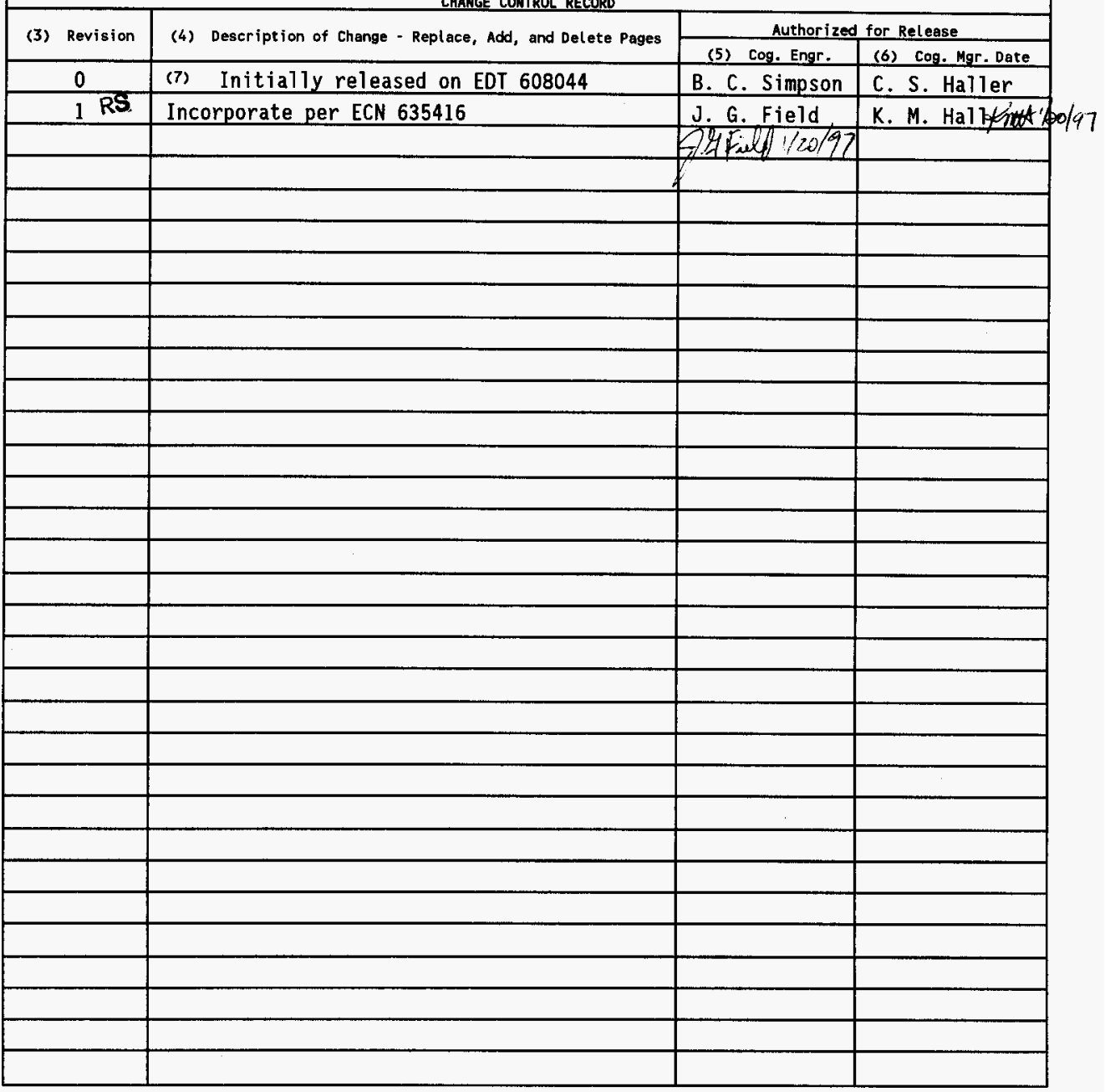


THIS PAGE INTENTIONALLY LEFT BLANK 


\title{
Tank Characterization Report for Double-Shell Tank 241-AP-103
}

\author{
J. G. Field \\ L. W. Shelton \\ Lockheed Martin Hanford Corporation \\ R. D. Cromar \\ Numatec Hanford Corporation \\ B. Morris \\ Los Alamos Technical Associates
}

Date Published

January 1997

Prepared for the U.S. Department of Energy

Assistant Secretary for Environmental Management

Project Hanford Management Contractor for the

U.S. Department of Energy under Contract DE-ACO6-98RL13200

Approved for public release; distribution is unlimited 
THIS PAGE INTENTIONALLY LEFT BLANK 


\section{CONTENTS}

1.0 INTRODUCTION $\ldots \ldots \ldots \ldots \ldots \ldots \ldots \ldots \ldots \ldots \ldots \ldots \ldots \ldots \ldots \ldots \ldots \ldots .1$

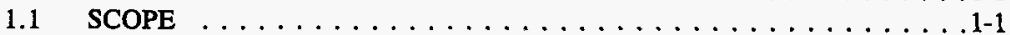

1.2 TANK BACKGROUND $\ldots \ldots \ldots \ldots \ldots \ldots \ldots \ldots \ldots \ldots \ldots$

2.0 RESPONSE TO TECHNICAL ISSUES $\ldots \ldots \ldots \ldots \ldots \ldots \ldots \ldots \ldots \ldots .1$

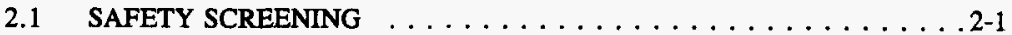

2.1.1 Exothermic Conditions (Energetics) $\ldots \ldots \ldots \ldots \ldots \ldots \ldots .2-1$

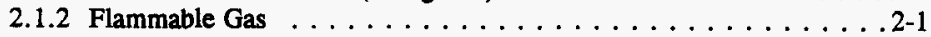

2.1 .3 Criticality . . . . . . . . . . . . . . . 2-2

2.2 OTHER TECHNICAL ISSUES $\ldots \ldots \ldots \ldots \ldots \ldots \ldots \ldots \ldots \ldots \ldots$

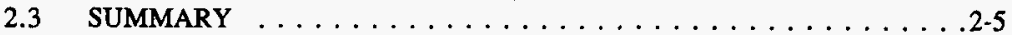

3.0 BEST-BASIS INVENTÓRY ESTIMATE $\ldots \ldots \ldots \ldots \ldots \ldots \ldots$ 3-1

4.0 CONCLUSIONS AND RECOMMENDATIONS $\ldots \ldots \ldots \ldots \ldots \ldots$ 4-1

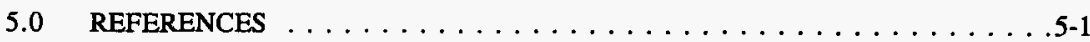

APPENDIX A: HISTORICAL TANK INFORMATTON $\ldots \ldots \ldots \ldots \ldots$ A-1

A1.0 CURRENT TANK STATUS $\ldots \ldots \ldots \ldots \ldots \ldots \ldots \ldots$ A

A2.0 TANK DESIGN AND BACKGROUND $\ldots \ldots \ldots \ldots \ldots \ldots \ldots$ A-4

A3.0 PROCESS KNOWLEDGE $\ldots \ldots \ldots \ldots \ldots \ldots \ldots \ldots \ldots \ldots$ A $\ldots \ldots$.9

A3.1 WASTE TRANSFER HISTORY $\ldots \ldots \ldots \ldots \ldots \ldots \ldots \ldots$ A-9

A3.2 HISTORICAL ESTIMATION OF TANK CONTENTS $\ldots \ldots \ldots \ldots$ A-10

A4.0 SURVEILLANCE DATA $\ldots \ldots \ldots \ldots \ldots \ldots \ldots \ldots \ldots \ldots \ldots \ldots \ldots$ A-14

A4.1 SURFACE LEVEL READINGS $\ldots \ldots \ldots \ldots \ldots \ldots \ldots \ldots \ldots$ A-14

A4.2 INTERNAL TANK TEMPERATURES $\ldots \ldots \ldots \ldots \ldots \ldots \ldots$ A-14

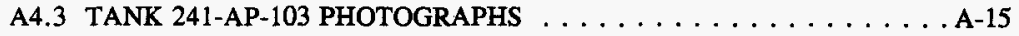

A5.0 APPENDIX A REFERENCES $\ldots \ldots \ldots \ldots \ldots \ldots \ldots \ldots \ldots \ldots$ A-18 


\section{CONTENTS (Continued)}

APPENDIX B: $\quad$ SAMPLING OF TANK $241-A P-103 \ldots \ldots \ldots \ldots$ B-1

B1.0 TANK SAMPLING OVERVIEW $\ldots \ldots \ldots \ldots \ldots \ldots \ldots \ldots \ldots$ B-3

B1.1 DESCRIPTION OF SAMPLING EVENT $\ldots \ldots \ldots \ldots \ldots \ldots$ B-3

B1.2 SAMPLE HANDLING $\ldots \ldots \ldots \ldots \ldots \ldots \ldots \ldots \ldots$ B-4

B1.3 SAMPLE ANALYSIS $\ldots \ldots \ldots \ldots \ldots \ldots \ldots \ldots$ B-5

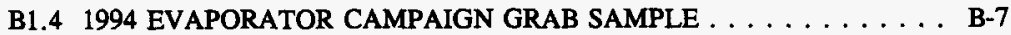

B1.5 DESCRIPTION OF HISTORICAL SAMPLING EVENT $\ldots \ldots \ldots \ldots$ B-7

B2.0 ANALYTICAL RESULTS $\ldots \ldots \ldots \ldots \ldots \ldots \ldots \ldots \ldots \ldots$ B-7

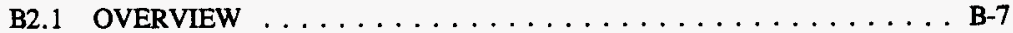

B2.2 INORGANIC ANALYSES $\ldots \ldots \ldots \ldots \ldots \ldots \ldots \ldots$ B-8

B2.2.1 Inductively Coupled Plasma Spectroscopy $\ldots \ldots \ldots \ldots \ldots$ B-8

B2.2.2 Gaseous Hydride Atomic Absorption Spectroscopy . . . . . . . B-9

B2.2.3 Cold Vapor Atomic Absorption Spectroscopy ... . . . . . . B-9

B2.2.4 Toxicity Characteristic Leaching Procedure . . . . . . . . B-9

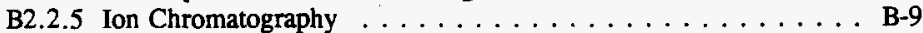

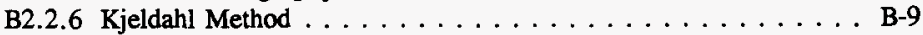

B2.2.7 Titration . . . . . . . . . . . . . . . . . . . . B-9

B2.2.8 Distillation/Spectrometric Analysis . . . . . . . . . . . B-9

B2.3 ORGANIC ANALYSES $\ldots \ldots \ldots \ldots \ldots \ldots \ldots \ldots \ldots \ldots$

B2.3.1 Total Inorganic Carbon . . . . . . . . . . . . . . B-10

B2.3.2 Total Organic Carbon . . . . . . . . . . . . . . B-10

B2.3.3 Volatile Organic Compounds $\ldots \ldots \ldots \ldots \ldots \ldots \ldots$ B-10

B2.3.4 Semivolatile Organic Compounds $\ldots \ldots \ldots \ldots \ldots \ldots$ B-10

B2.4 RADIOCHEMICAL ANALYSES $\ldots \ldots \ldots \ldots \ldots \ldots \ldots \ldots$ B-11

B2.4.1 Gamma Energy Analysis . . . . . . . . . . . B-11

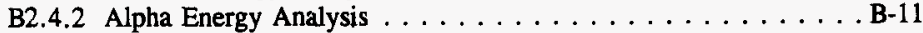

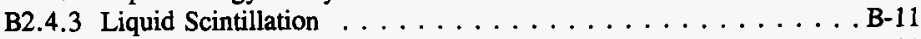

B2.4.4 Alpha Proportional Counting $\ldots \ldots \ldots \ldots \ldots \ldots \ldots$ B-11

B2.4.5 Beta Proportional Counting $\ldots \ldots \ldots \ldots \ldots \ldots \ldots$ B-11

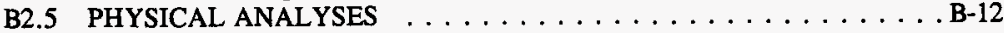

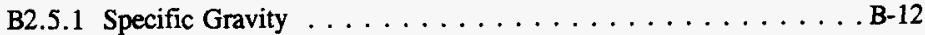

B2.6 THERMODYNAMIC ANALYSES $\ldots \ldots \ldots \ldots \ldots \ldots \ldots$ B-12

B2.6.1 Differential Scanning Calorimetry $\ldots \ldots \ldots \ldots \ldots \ldots$ B-12

B2.7 HISTORICAL SAMPLE RESULTS $\ldots \ldots \ldots \ldots \ldots \ldots \ldots \ldots \ldots$ B-34

B3.0 ASSESSMENT OF CHARACTERIZATION RESULTS $\ldots \ldots \ldots \ldots \ldots$ B-35

B3.1 FIELD OBSERVATIONS $\ldots \ldots \ldots \ldots \ldots \ldots \ldots \ldots \ldots \ldots$ B-35

B3.2 QUALITY CONTROL ASSESSMENT $\ldots \ldots \ldots \ldots \ldots \ldots \ldots$ B-35 
CONTENTS (Continued)

B3.3 DATA CONSISTENCY CHECKS . . . . . . . . . . . . B-36 B3.3.1 Comparison of Results from Different Analytical Methods . . . B-36 B3.3.2 Mass and Charge Balance . . . . . . . . . . . B-36 B3.4 CALCULATION OF ANALYTICAL BASED MEANS AND INVENTORY $\ldots \ldots \ldots \ldots \ldots \ldots \ldots \ldots \ldots \ldots \ldots \ldots$ B-38

B4.0 APPENDIX B REFERENCES $\ldots \ldots \ldots \ldots \ldots \ldots \ldots \ldots \ldots \ldots$ B-41

APPENDIX C: $\quad$ STATISTICAL ANALYSIS FOR ISSUE RESOLUTION $\ldots \ldots$ C-1

C1.0 STATISTICS FOR SAFETY SCREENING DQO $\ldots \ldots \ldots \ldots \ldots \ldots$ C-3

C2.0 APPENDIX C REFERENCES $\ldots \ldots \ldots \ldots \ldots \ldots \ldots \ldots \ldots \ldots$ C-3

APPENDIX D: $\quad$ EVALUATION TO ESTABLISHED BEST-BASIS INVENTORY FOR TANK $241-A P-103 \ldots \ldots \ldots \ldots \ldots$ D-1

D1.0 CHEMICAL INFORMATION SOURCES $\ldots \ldots \ldots \ldots \ldots \ldots$ D-3

D2.0 COMPARISON OF COMPONENT INVENTORY VALUES $\ldots \ldots \ldots \ldots$ D-3

D3.0 COMPONENT INVENTORY EVALUATION $\ldots \ldots \ldots \ldots \ldots$ D-5

D4.0 DEFINE THE BEST BASIS AND ESTABLISH COMPONENT INVENTORIES $\ldots \ldots \ldots \ldots \ldots \ldots \ldots \ldots$

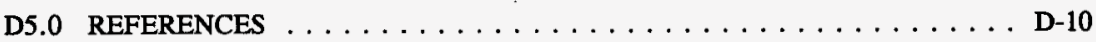

APPENDIX E: $\quad$ BIBLIOGRAPHY FOR TANK 241 -AP-103 $\ldots \ldots \ldots \ldots$ E-1 


\section{LIST OF FIGURES}

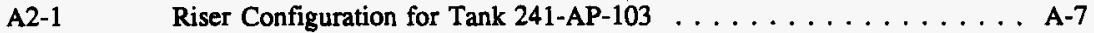

A2-2 Tank 241-AP-103 Cross Section and Schematic $\ldots \ldots \ldots \ldots \ldots$ A-8

A3-1 Tank Layer Model for Tank $241-$ AP-103 . . . . . . . . . . . . . A-14

A4-1 Tank 241-AP-103 Level History $\ldots \ldots \ldots \ldots \ldots \ldots \ldots$. . . . . . . .

A4-2 Tank 241-AP-103 Weekly High Temperature Plot $\ldots \ldots \ldots \ldots$ A-17

\section{LIST OF TABLES}

1-1 Summary of 1991 Grab Sampling Event $\ldots \ldots \ldots \ldots \ldots \ldots$ 1-2

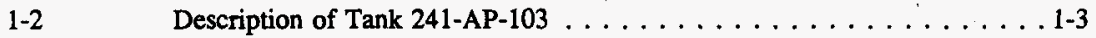

2-1 Tank 241-AP-103 Radionuclide Inventory and Projected Heat Load . . . 2-2

2-2 Summary of Safety Screening and Waste Compatibility Results . . . . 2-3

3-1 Best-Basis Inventory Estimates for Nonradioactive Components in Tank 241-AP-103 as of October $21,1996 . \ldots \ldots \ldots \ldots \ldots \ldots$ 3-2

3-2 Best-Basis Inventory Estimates for Radioactive Components in Tank 241-AP-103 as of October $21,1996 . \ldots \ldots \ldots \ldots \ldots \ldots$. . . . . .

4-1 Acceptance of Tank 241-AP-103 Sampling and Analysis . . . . . . 4-1

4-2 Acceptance of Evaluation of Characterization Data and Information for Tank 241-AP-103 . . . . . . . . . . . . 4-2

A1-1 Estimated Tank Contents $\ldots \ldots \ldots \ldots \ldots \ldots \ldots \ldots \ldots$ A-4

A2-1 Tank $241-$ AP-103 Risers $\ldots \ldots \ldots \ldots \ldots \ldots \ldots \ldots \ldots$ A-5

A3-1 Summary of Tank 241-AP-103 Major Waste Transfers $\ldots \ldots \ldots$ A-10

A3-2 Tank 241-AP-103 Historical Tank Inventory Estimate $\ldots \ldots \ldots \ldots$ A-12

B1-1 Tank 241-AP-103 Sample Information . . . . . . . . . B-4 


\section{LIST OF TABLES (Continued)}

B1-2 Summary of Samples and Requested Analytes $\ldots \ldots \ldots \ldots$ B-5

B1-3 General Analytical Methods $\ldots \ldots \ldots \ldots \ldots \ldots \ldots$ B-6

B2-1 Analytical Presentation Tables $\ldots \ldots \ldots \ldots \ldots \ldots \ldots$ B-7

B2-2 Tank 241-AP-103 Analytical Results: Aluminum $\ldots \ldots \ldots \ldots$. . . . . .

B2-3 Tank 241-AP-103 Analytical Results: Barium $\ldots \ldots \ldots \ldots \ldots$ B-13

B2-4 Tank 241-AP-103 Analytical Results: Cadmium . . . . . . . . . . B-14

B2-5 Tank 241-AP-103 Analytical Results: Chromium $\ldots \ldots \ldots \ldots \ldots$. . . . .

B2-6 Tank 241-AP-103 Analytical Results: Iron $\ldots \ldots \ldots \ldots \ldots \ldots$ B-15

B2-7 Tank 241-AP-103 Analytical Results: Lead . . . . . . . . . . . . B-15

B2-8 Tank 241-AP-103 Analytical Results: Magnesium . . . . . . . . B-16

B2-9 Tank 241-AP-103 Analytical Results: Manganese . . . . . . . . . B-16

B2-10 Tank 241-AP-103 Analytical Results: Silver $\ldots \ldots \ldots \ldots \ldots \ldots$ B-17

B2-11 Tank 241-AP-103 Analytical Results: Sodium $\ldots \ldots \ldots \ldots \ldots$ B-17

B2-12 Tank 241-AP-103 Analytical Results: Zinc $\ldots \ldots \ldots \ldots \ldots \ldots$ B-18

B2-13 Tank 241-AP-103 Analytical Results: Arsenic $\ldots \ldots \ldots \ldots \ldots$ B-18

B2-14 Tank 241-AP-103 Analytical Results: Selenium . . . . . . . . . . B-19

B2-15 Tank 241-AP-103 Analytical Results: Mercury $\ldots \ldots \ldots \ldots$. . . . . .

B2-16 Tank 241-AP-103 Analytical Results: Chloride $\ldots \ldots \ldots \ldots \ldots$ B-20

B2-17 Tank 241-AP-103 Analytical Results: Fluoride $\ldots \ldots \ldots \ldots \ldots$ B-20

B2-18 Tank 241-AP-103 Analytical Results: Nitrate $\ldots \ldots \ldots \ldots \ldots$ B-21

B2-19 Tank 241-AP-103 Analytical Results: Nitrite $\ldots \ldots \ldots \ldots \ldots \ldots$. . . . 1 


\section{LIST OF TABLES (Continued)}

B2-20

B2-21

B2-22

B2-23

B2-24

B2-25

B2-26

B2-27

B2-28

B2-29

B2-30

B2-31

B2-32

B2-33

B2-34

B2-35

B2-36

B2-37

B2-38

B2-39

B2-40
Tank 241-AP-103 Analytical Results: Phosphate

Tank 241-AP-103 Analytical Results: Sulfate

B-22

Tank 241-AP-103 Analytical Results: Ammonia

B-23

Tank 241-AP-103 Analytical Results: Hydroxide

Tank 241-AP-103 Analytical Results: Cyanide . . . . . . . . . . B B-24

Tank 241-AP-103 Analytical Results: Total Inorganic Carbon . . . . . B-24

Tank 241-AP-103 Analytical Results: Total Organic Carbon . . . . . . B-25

Tank 241-AP-103 Analytical Data: Volatile Organics . . . . . . . B-25

Tank 241-AP-103 Analytical Data: Acetone $\ldots \ldots \ldots \ldots \ldots \ldots$ B-26

Tank 241-AP-103 Analytical Data: Semivolatile Organics . . . . . . . B-27

Tank 241-AP-103 Analytical Data: 2,4-Dichloropentane . . . . . . . . B-28

Tank 241-AP-103 Analytical Results: Ce/Pr-144 . . . . . . . . . B-28

Tank 241-AP-103 Analytical Results: Cesium-134 . . . . . . . . B-28

Tank 241-AP-103 Analytical Results: Cesium-137 . . . . . . . . . B-29

Tank 241-AP-103 Analytical Results: Cobalt-60 . . . . . . . . . . . B-29

Tank 241-AP-103 Analytical Results: Eu-154/155 . . . . . . . . . B-29

Tank 241-AP-103 Analytical Results: Europium-154 . . . . . . . . B-30

Tank 241-AP-103 Analytical Results: Europium-155 . . . . . . . . . B-30

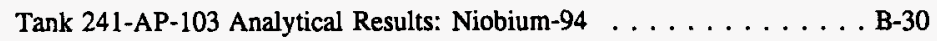

Tank 241-AP-103 Analytical Results: Niobium-95 . . . . . . . . . B-30

Tank 241-AP-103 Analytical Results: Radium-226 . . . . . . . . B-31 


\section{LIST OF TABLES (Continued)}

B2-41 Tank 241-AP-103 Analytical Results: Ruthenium/Rhodium-106 . . . . B-31

B2-42 Tank 241-AP-103 Analytical Results: Tin-113 . . . . . . . . B-31

B2-43 Tank 241-AP-103 Analytical Results: Iodine-129 . . . . . . . . . B-31

B2-44 Tank 241-AP-103 Analytical Data: Uranium-234 . . . . . . . . . B-31

B2-45 Tank 241-AP-103 Analytical Data: Uranium-235 . . . . . . . B-32

B2-46 Tank 241-AP-103 Analytical Data: Uranium-238 . . . . . . . . B-32

B2-47 Tank 241-AP-103 Analytical Results: Americium-241 . . . . . . . B-32

B2-48 Tank 241-AP-103 Analytical Results: Plutonium-239/240 . . . . . . . . B-32

B2-49 Tank 241-AP-103 Analytical Results: Carbon-14 . . . . . . . . . B-32

B2-50 Tank 241-AP-103 Analytical Results: Selenium-79 . . . . . . . . B-32

B2-51 Tank 241-AP-103 Analytical Results: Tritium . . . . . . . . . B-33

B2-52 Tank 241-AP-103 Analytical Results: Technetium-99 . . . . . . . B-33

B2-53 Tank 241-AP-103 Analytical Results: Total Uranium . . . . . . . . . . B-33

B2-54 Tank 241-AP-103 Analytical Results: Strontium-90 . . . . . . . . B-33

B2-55 Tank 241-AP-103 Analytical Results: Specific gravity . . . . . . . . B-34

B3-1 Comparison of Total Uranium Results from

Different Analytical Methods . . . . . . . . . . . . . B-36

B3-2 Cation Mass and Charge Data $\ldots \ldots \ldots \ldots \ldots \ldots \ldots$ B-37

B3-3 Anion Mass and Charge Data $\ldots \ldots \ldots \ldots \ldots \ldots \ldots$ B-37

B3-4 Charge Balance and Calculation of Weight Percent Water . . . . . . B-38

B3-5 95 Percent Two-Sided Confidence Interval for the Mean Concentration. . B-39 


\section{LIST OF TABLES (Continued)}

D2-1 Sampling and Hanford Defined Waste Model Inventory Estimates for Nonradioactive Components in DST 241-AP-103 . . . . . . . . D-4

D2-2 Sampling and Hanford Defined Waste Model Inventory Estimates for Radioactive Components in Double-Shell Tank 241-AP-103 . . . . . D D-5

D4-1 Best-Basis Inventory Estimates for Nonradioactive Components in Tank 241-AP-103 as of October 21, $1996 \ldots \ldots \ldots \ldots \ldots$ D-7

D4-2 Best-Basis Inventory Estimates for Radioactive Components in Tank 241-AP-103 as of October 21, $1996 \ldots \ldots \ldots \ldots \ldots \ldots$ D-8 


\section{LIST OF TERMS}

\begin{tabular}{|c|c|}
\hline${ }^{\circ} \mathrm{C}$ & degrees Celsius \\
\hline${ }^{\circ} \mathrm{F}$ & degrees Fahrenheit \\
\hline$\mu \mathrm{Ci} / \mathrm{g}$ & microcuries per gram \\
\hline$\mu \mathrm{Ci} / \mathrm{L}$ & microcuries per liter \\
\hline$\mu \mathrm{eq} / \mathrm{g}$ & microequivalents per gram \\
\hline$\mu \mathrm{g} / \mathrm{g}$ & micrograms per gram \\
\hline$\mu \mathrm{g} / \mathrm{L}$ & micrograms per liter \\
\hline$\mu \mathrm{g} / \mathrm{mL}$ & micrograms per milliliter \\
\hline Btu/hr & British thermal units per hour \\
\hline $\mathrm{Ci}$ & curies \\
\hline $\mathrm{Ci} / \mathrm{L}$ & curies per liter \\
\hline $\mathrm{cm}$ & centimeters \\
\hline CVAA & cold vapor atomic absorption \\
\hline DQO & data quality objectives \\
\hline DSC & differential scanning calorimetry \\
\hline FIC & Food Instrument Corporation \\
\hline $\mathrm{ft}$ & feet \\
\hline $\mathrm{g} / \mathrm{L}$ & grams per liter \\
\hline $\mathrm{g} / \mathrm{mL}$ & grams per milliliter \\
\hline HDW & Hanford defined waste \\
\hline in. & inch \\
\hline $\mathrm{J} / \mathrm{g}$ & joules per gram \\
\hline $\mathrm{kg}$ & kilograms \\
\hline kgal & kilogallons \\
\hline $\mathrm{kL}$ & kiloliters \\
\hline LANL & Los Alamos National Laboratory \\
\hline LL & lower limit \\
\hline $\mathrm{m}$ & meters \\
\hline$\underline{\mathbf{M}}$ & moles per liter \\
\hline$\overline{\mathrm{mL}}$ & milliliters \\
\hline $\mathrm{mm}$ & millimeters \\
\hline ND & not detected \\
\hline N/D & not decided \\
\hline $\mathbf{N} / \mathbf{R}$ & not reviewed \\
\hline PASF & PUREX ammonia scrubber feed \\
\hline PHMC & Project Hanford Management Contract \\
\hline $\mathrm{ppb}$ & parts per billion \\
\hline ppm & parts per million \\
\hline PUREX & Plutonium-Uranium Extraction \\
\hline $\mathrm{QC}$ & quality control \\
\hline REML & restricted maximum likelihood estimation \\
\hline RPD & relative percent difference \\
\hline
\end{tabular}




\section{LIST OF TERMS (Continued)}

SACS

SpG

TCR

TIC

TOC

TRU

TWRS

UL

W

$\mathrm{W} / \mathrm{Ci}$

wt\%
Surveillance Analysis Computer System

specific gravity

tank characterization report

total inorganic carbon

total organic carbon

transuranic

Tank Waste Remediation System

upper limit

watts

watts per curie

weight percent 


\subsection{INTRODUCTION}

One of the major functions of the Tank Waste Remediation System (TWRS) is to characterize wastes in support of waste management and disposal activities at the Hanford Site. Analytical data from sampling and analysis, along with other available information about a tank, are compiled and maintained in a tank characterization report (TCR). This report and its appendices serve as the TCR for double-shell tank 241-AP-103. The objectives of this report are: 1) to use characterization data in response to technical issues associated with 241-AP-103 waste; and 2) to provide a standard characterization of this waste in terms of a best-basis inventory estimate. The response to technical issues is summarized in Section 2.0, and the best-basis inventory estimate is presented in Section 3.0. Recommendations regarding safety status and additional sampling needs are provided in Section 4.0. Supporting data and information are contained in the appendices. This report also supports the requirements of the Hanford Federal Facility Agreement and Consent Order (Ecology et al. 1996) milestone M-44-05.

\subsection{SCOPE}

Characterization information presented in this report originated from sample analyses and known (historical) sources. While the data quality objectives (DQOs) required that technical issues be resolved using results from recent sampling events (listed in Table 1-1), other information could be used to support (or challenge) conclusions derived from these results. Historical information for tank 241-AP-103, provided in Appendix A, includes surveillance information, records pertaining to waste transfers and tank operations, and expected tank contents derived from a process knowledge model.

The 1991 grab sample event listed in Table 1-1, a 1994 sampling event, and a sample event before 1989, are summarized in Appendix B along with the sampling results. The 1994 sample was composited with samples from two other tanks and analyzed for organics only. The 1991 sample satisfied data requirements specified in the tank waste analysis plan (Halgren 1991) and was the basis used in this report for tank inventory estimates. Both the 1991 and 1994 samples were obtained prior to transferring the majority of the tank contents to tank 241-AW-102 as 242-A Evaporator feed. The statistical analysis and numerical manipulation of data used in issue resolution are reported in Appendix C. Appendix D contains the evaluation to establish the best basis for the inventory estimate and the statistical analysis performed for this evaluation. A bibliography that resulted from an in-depth literature search of all known information sources applicable to tank 241-AP-103 and its respective waste types is contained in Appendix E. The reports listed in Appendix $\mathrm{E}$ may be found in the Tank Characterization Resource Center. 


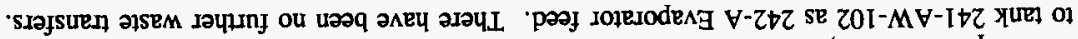

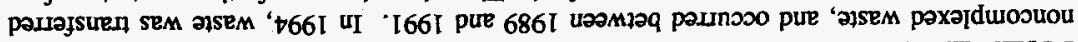

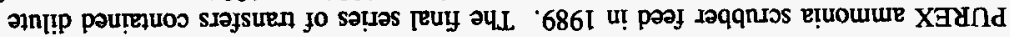

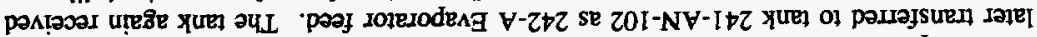

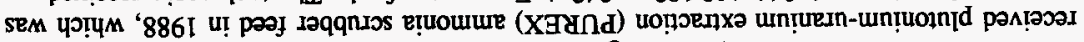

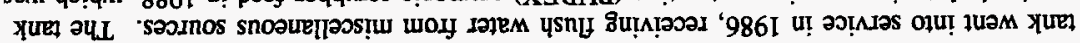

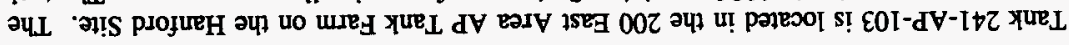

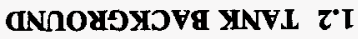

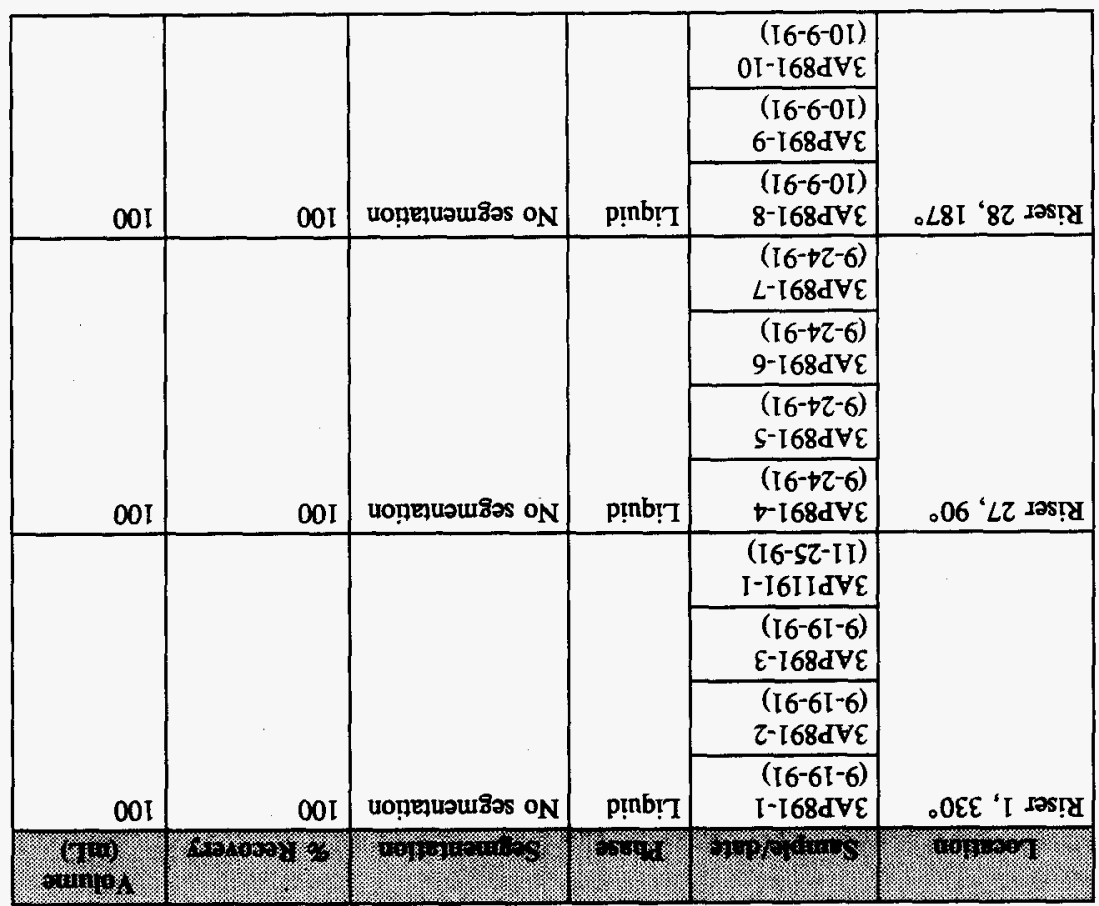

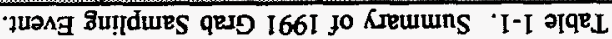


A description of tank 241-AP-103 is summarized in Table 1-2. The tank has an operating capacity of $4,390 \mathrm{~kL}(1,160 \mathrm{kgal})$, and presently contains an estimated $87 \mathrm{~kL}$ (23 kgal) of dilute non-complexed waste (Hanlon 1996). The tank is not on the Watch List .

(Public Law 101-510).

Table 1-2. Description of Tank 241-AP-103.

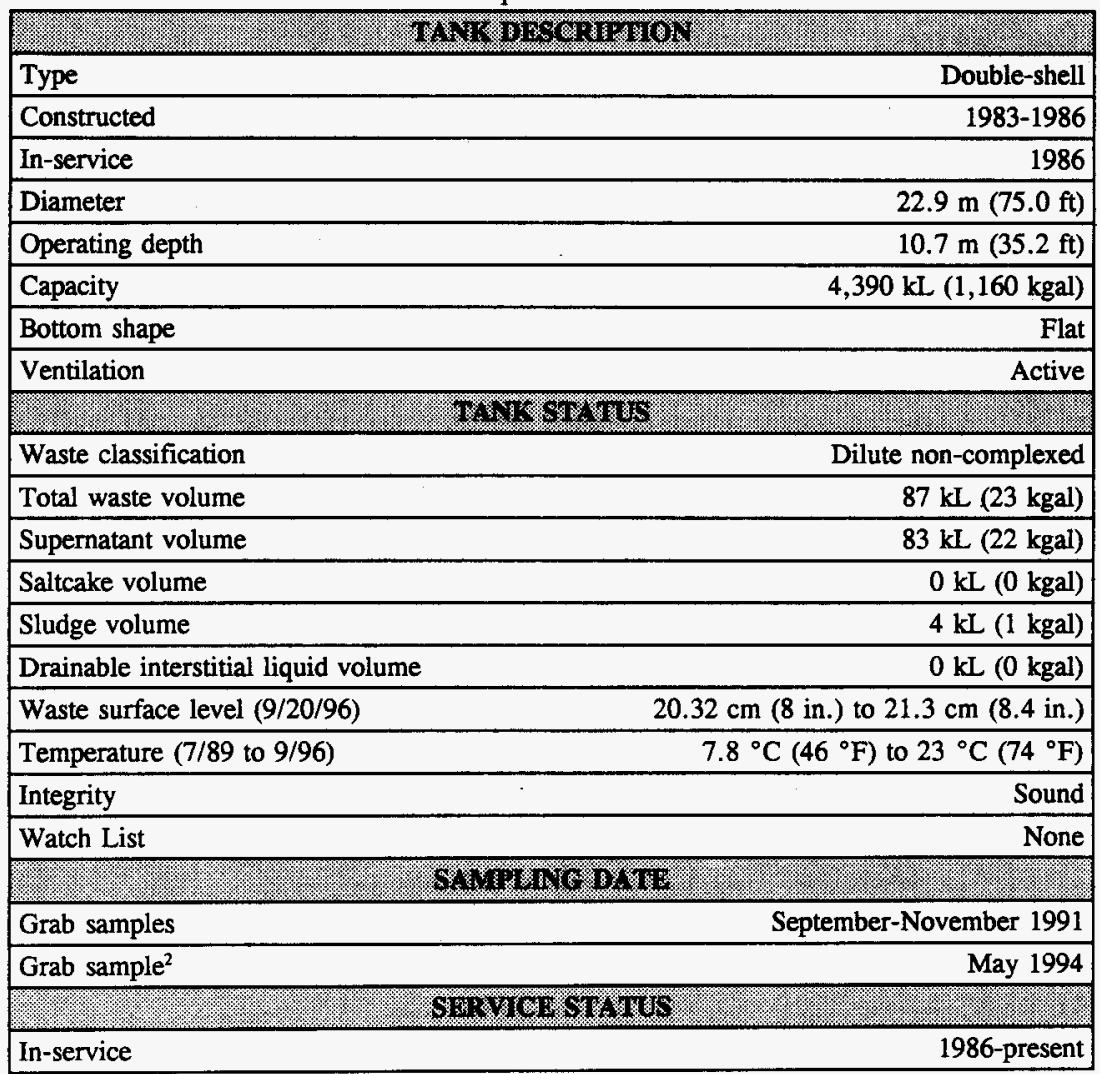

Note:

'Waste volume is estimated from surface level measurements.

2This grab sample was mixed with samples from tanks 241-AW-102 and 241-AW-106 for SemiVOA analysis in support of 242-A Evaporator campaign 94-1. Results are included in Appendix B. 
HNF-SD-WM-ER-359, Rev. 1

This page left blank intentionally. 


\subsection{RESPONSE TO TECHNICAL ISSUES}

The technical issue identified for tank 241-AP-103 (Brown et al. 1995) is:

- Does the waste pose or contribute to any recognized potential safety problems?

Data from the recent analysis of grab samples, as well as available historical information, provided the means to respond to this issue. This response is detailed in the following sections. See Appendix B for sample and analysis data for tank 241-AP-103.

Before the 1994 transfer, evaporator DQOs and compatibility DQOs also applied to tank 241-AP-103. However, compatibility DQOs no longer apply because compatibility analyses were completed and approved prior to the tank transfer. The evaporator DQO does not currently apply because no additional waste is currently available for transfer to the 242-A Evaporator. As a result, these issues are not addressed by this report.

\subsection{SAFETY SCREENING}

The data needed to screen the waste in tank 241-AP-103 for potential safety problems are documented in Tank Safety Screening Data Quality Objective (Dukelow et al. 1995). These potential safety problems are exothermic conditions in the waste, flammable gases in the waste and/or tank headspace, and criticality conditions in the waste. Each of these conditions is addressed separately below.

\subsubsection{Exothermic Conditions (Energetics)}

The first requirement outlined in the safety screening DQO (Dukelow et al. 1995) is to ensure that there are not enough exothermic constituents (organic or ferrocyanide) to cause a safety hazard. Because of this requirement, energetics in the tank 241-AP-103 waste were evaluated. The threshold limit for energetics is $480 \mathrm{~J} / \mathrm{g}$ on a dry weight basis. There were no exothermic reactions detected in any of the samples (WHC 1992).

\subsubsection{Flammable Gas}

Determination of the tank headspace flammability was not required when the tank was sampled in 1991. As a result, this safety screening DQO issue was not addressed. The concentration of flammable gases in the tank headspace is anticipated to be very low because of the low levels of radionuclides and organic compounds in the tank, and because the tank is actively ventilated. 


\subsubsection{Criticality}

The safety threshold limit for criticality is $1 \mathrm{~g}{ }^{239} \mathrm{Pu}$ per liter of waste. Assuming that all alpha activity is from ${ }^{239} \mathrm{Pu}$ and assuming a density of $1.5 \mathrm{~g} / \mathrm{mL}$ or less, $1 \mathrm{~g} / \mathrm{L}$ of ${ }^{239} \mathrm{Pu}$ is greater than or equal to $41 \mu \mathrm{Ci} / \mathrm{g}$ of alpha activity. A composite sample was obtained from the grab samples and was analyzed for ${ }^{239240} \mathrm{Pu}$. The composite results were well below this limit, with a result of $<0.00697 \mu \mathrm{Ci} / \mathrm{L}(<6.97 \mathrm{E}-06 \mu \mathrm{Ci} / \mathrm{g})$. Therefore, criticality is not an issue for this tank. Because the results were below analytical detection limits, a 95 percent confidence interval was not calculated.

\subsection{OTHER TECHNICAL ISSUES}

The determination of total organic carbon (TOC) is used to evaluate the fuel content of the tank waste. Although not required as a primary analyte by the current safety screening DQO, TOC was a required analyte of the 1991 samples. The TOC results were evaluated to the decision limits of the safety screening DQO (Dukelow et al. 1995). All results were below the action limit of $30,000 \mu \mathrm{g} / \mathrm{g}$ (dry weight basis), with a dry weight mean of $6,470 \mu \mathrm{g} / \mathrm{g}$.

A factor in assessing tank safety is heat generation from radioactive decay. The tank heat load calculated from the best-basis inventory data of Section 3 was $2.41 \mathrm{~W}(8.22 \mathrm{Btu} / \mathrm{hr})$ (Table 2-1). The Agnew et al. (1996) estimate of heat load was $434 \mathrm{~W}$ (1,480 Btu/hr). These estimates are well below the $20,500-\mathrm{W}(70,000-\mathrm{Btu} / \mathrm{hr})$ operating specification limit for double-shell tanks (Harris 1994).

Table 2-1. Tank 241-AP-103 Radionuclide Inventory and Projected Heat Load.

\begin{tabular}{|c|c|c|c|}
\hline (1. & $\frac{1}{4}$ & 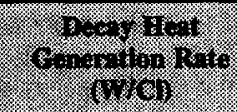 & 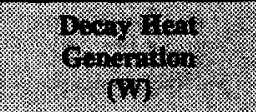 \\
\hline${ }^{137} \mathrm{Cs}$ & 472 & 0.00472 & 2.23 \\
\hline${ }^{89 / 90} \mathrm{Sr}$ & 0.175 & 0.00669 & 0.00117 \\
\hline${ }^{99} \mathrm{Tc}$ & 358 & 5.01E-04 & 0.179 \\
\hline \multicolumn{4}{|l|}{ Total Watts } \\
\hline
\end{tabular}




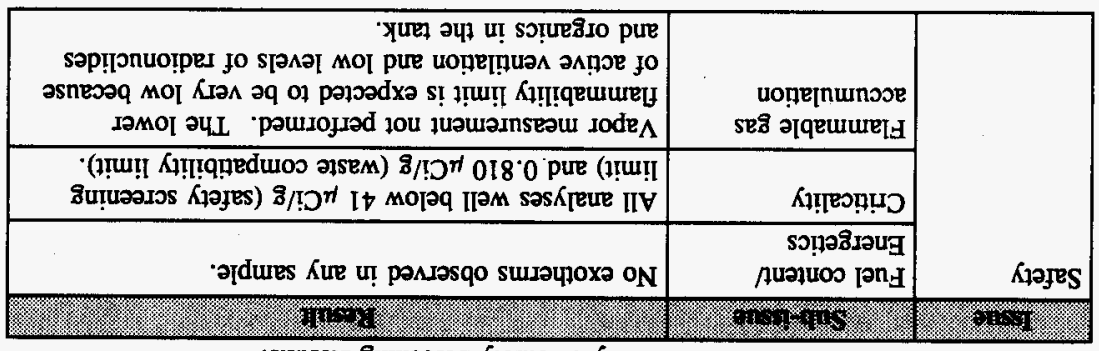

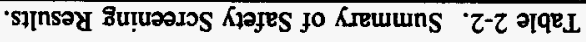

$\cdot(z-z$ गqस $\mathrm{L})$

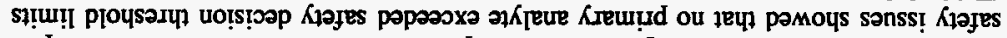

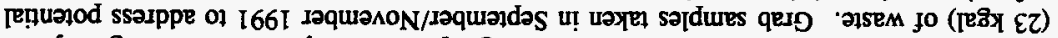

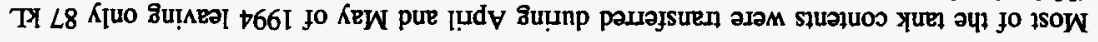


HNF-SD-WM-ER-359, Rev. 1

This page left blank intentionally. 


\subsection{BEST-BASIS INVENTORY ESTIMATE}

Information about the chemical and/or physical properties of tank wastes is used to perform safety analyses, engineering evaluations, and risk assessments associated with waste management activities, as well as to address regulatory issues. These activities include overseeing tank farm operations and identifying, monitoring, and resolving safety issues associated with these operations and with the tank wastes. Disposal activities involve designing equipment, processes, and facilities for retrieving wastes and processing them into a form that is suitable for long-term storage. Chemical inventory information generally is derived using two approaches: (1) component inventories are estimated using the results of sample analyses; or (2) component inventories are predicted using a model based on process knowledge and historical information. The most recent model was developed by Los Alamos National Laboratory (LANL) (Agnew et al. 1996). Information derived from these two different approaches is often inconsistent.

An effort is underway to provide waste inventory estimates that will serve as standard characterization for the various waste management activities (Hodgson et al. 1996). As a part of this effort, an evaluation of available chemical information for tank 241-AP-103 was performed that included the following:

- Data from bottle-on-a-string samples collected in September, October, and November, 1991 (De Lorenzo et al. 1994)

- The inventory estimate for this tank generated from the LANL model (Agnew et al. 1996), also referred to as the historical tank content estimate.

Results from this evaluation, detailed in Appendix D, support using the sampling data as the basis for the best estimate inventory for tank 241-AP-103 for the following reasons:

1. The LANL model assumptions about the solubilities of many components in an alkaline environment have a high bias.

2. Statistical analysis of tank sample data indicated that the contents were homogeneous.

3. Laboratory analysis of dilute liquids demonstrating little or no stratification are normally precise and accurate.

Best-basis inventory estimates for tank 241-AP-103 are presented in Tables 3-1 and 3-2. While samples were analyzed for numerous analytes, only those detected in the waste are included in these tables. A tank volume of $87 \mathrm{~kL}$ (23 kgal) (Hanlon 1996) was used to calculate these inventories. 
'(g x!̣puodd

paseq-jtrocussesse 8ี4

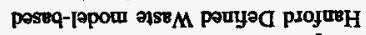
peseq-e[dures

$$
\begin{array}{lr}
= & \boldsymbol{B} \\
= & \mathbf{W} \\
= & \mathbf{S}_{1}
\end{array}
$$

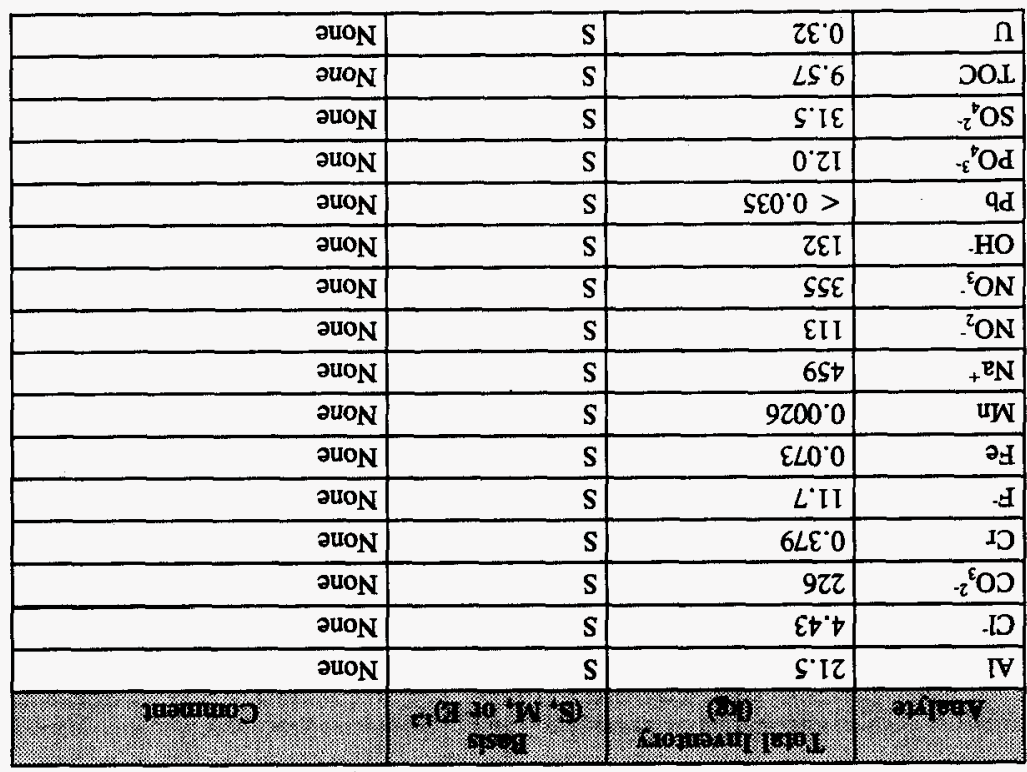

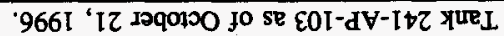

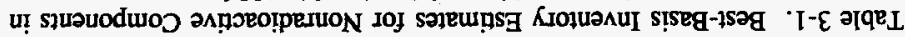


Table 3-2. Best-Basis Inventory Estimates for Radioactive Components in

Tank 241-AP-103 as of October 21, 1996.

\begin{tabular}{|c|c|c|c|}
\hline 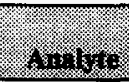 & 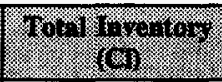 & 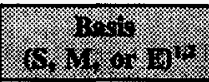 & (2) \\
\hline${ }^{79} \mathrm{Se}$ & 9.70E-04 & $S$ & None \\
\hline${ }^{90} \mathrm{Sr}$ & 0.23 & 5 & None \\
\hline${ }^{99} \mathrm{Tc}$ & 0.094 & $S$ & None \\
\hline${ }^{137} \mathrm{Cs}$ & 577 & $S$ & None \\
\hline${ }^{234} \mathrm{U}$ & $5.70 \mathrm{E}-04$ & $S$ & None \\
\hline${ }^{235} \mathrm{U}$ & 2.95E-05 & $S$ & None \\
\hline${ }^{238} \mathrm{U}$ & $1.10 \mathrm{E}-04$ & $S$ & None \\
\hline${ }^{241} \mathrm{Am}$ & $9.87 \mathrm{E}-04$ & $S$ & None \\
\hline
\end{tabular}

Notes:

$$
\begin{array}{lll}
{ }^{1} \mathbf{S} & = & \text { Sample-based } \\
\mathbf{M} & = & \text { Hanford Defined Waste model-based } \\
\mathbf{E} & = & \text { Engineering assessment-based }
\end{array}
$$

2Based on 1991 grab samples (see Appendix B) 
HNF-SD-WM-ER-359, Rev. 1

This page left blank intentionally. 


\subsection{CONCLUSIONS AND RECOMMENDATIONS}

Tank 241-AP-107 was characterized based on grab samples obtained in September/November 1991. The samples were obtained to satisfy safety and operations issues in support of the 94-1 Evaporator campaign, and meet most of the current safety DQOs.

All analytical results for the safety screening DQO were well within the safety notification limits; however, the flammability of the tank headspace was not determined. This issue needs to be addressed to fully satisfy the safety screening DQO. However, the tank is actively ventilated, with no evidence of flammable gas accumulation. Based on low radionuclide and organic concentrations, the concentration of flammable gases in the tank headspace is anticipated to be very low.

Analytical results from the 1991 sampling event were used to determine the best-basis inventory for the tank contents.

Table 4-1 summarizes the status of TWRS Program review and acceptance of the sampling and analysis results reported in this tank characterization report. All DQO issues required to be addressed by sampling and analysis are listed in column one of Table 4-1. The second column indicates whether the requirements of the DQO were met by the sampling and analysis activities performed. The third column indicates concurrence and acceptance by the program in TWRS that is responsible for the DQO that the sampling and analysis activities performed adequately meet the needs of the DQO. A "yes" or "no" in column three indicates acceptance or disapproval of the sampling and analysis information presented in the TCR. If the results/information have not yet been reviewed, "N/R" is shown in the column. If the results/information have been reviewed, but acceptance or disapproval has not been decided, "N/D" is shown in the column.

Table 4-1. Acceptance of Tank 241-AP-103 Sampling and Analysis.

\begin{tabular}{|l|l|l|l|l|}
\hline & & & \\
\hline Safety Screening DQO & Partial & Yes \\
\hline
\end{tabular}

Notes:

'Project Hanford Management Contract (PHMC) TWRS Program Office 
Table 4-2 summarizes the status of TWRS Program review and acceptance of the evaluations and other characterization information contained in this report. The evaluations specifically outlined in this report are the best-basis inventory evaluation and the evaluation to determine whether the tank is safe, conditionally safe, or unsafe. Column one lists the different evaluations performed in this report. Columns two and three are in the same format as Table 4-1. The manner in which concurrence and acceptance are summarized is also the same as that in Table 4-1. The safety categorization of the tank is listed as "partial" in Table 4-2 because tank headspace flammability was not determined. However, none of the analyses performed indicate any safety problems.

Table 4-2. Acceptance of Evaluation of Characterization Data and Information for Tank 241-AP-103.

\begin{tabular}{|c|c|c|}
\hline 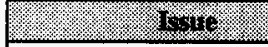 & 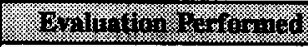 & 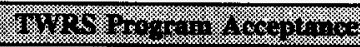 \\
\hline Safety categorization & Partial & Yes \\
\hline
\end{tabular}




\section{S.0 REFERENCES}

Agnew, S. F., J. Boyer, R. A. Corbin, T. B. Duran, J. R. Fitzpatrick, K. A. Jurgensen, T. P. Ortiz, and B. L. Young, 1996, Hanford Tank Chemical and Radionuclide Inventories: HDW Model Rev. 3, LA-UR-96-858, Los Alamos National Laboratory, Los Alamos, New Mexico.

Brown, T. M., S. J. Eberlein, S. W. Hunt, and T. J. Kunthara, 1996, Tank Waste Characterization Basis, WHC-SD-WM-TA-164, Rev. 2, Westinghouse Hanford Company, Richland, Washington.

De Lorenzo, D. S., A. T. DiCenso, L. C. Amato, J. D. Franklin, R. W. Lambie and B. C. Simpson, 1994, Tank Characterization Report for Double-Shell Tank 241-AP-103, WHC-SD-WM-ER-359, Rev. 0, Westinghouse Hanford Company, Richland, Washington.

Dukelow, G. T., J. W. Hunt, H. Babad, and J. E. Meacham, 1995, Tank Safety Screening Data Quality Objective, WHC-SD-WM-SP-004, Rev. 2, Westinghouse Hanford Company, Richland, Washington.

Ecology, EPA and DOE, 1996, Hanford Federal Facility Agreement and Consent Order, as amended, Washington State Department of Ecology, U.S. Environmental Protection Agency, and U.S. Department of Energy, Olympia, Washington.

Fowler, K. D., 1995, Data Quality Objectives for Tank Farms Waste Compatibility Program, WHC-SD-WM-DQO-001, Rev. 1, Westinghouse Hanford Company, Richland, Washington.

Halgren, D. L., 1991, Double-Shell Tank Waste Analysis Plan, WHC-SD-WM-EV-053, Rev. 1, Westinghouse Hanford Company, Richland, Washington.

Harris, J. P., 1994, Operating Specifications for the 241-AN, AP, AW, AY, AZ, \& SY Tank Farms, OSD-T-151-00007, Rev./Mod. H-8, Westinghouse Hanford Company, Richland, Washington.

Hanlon, B. M., 1996, Waste Tank Summary Report for Month Ending July 31, 1996, WHC-EP-0182-100, Westinghouse Hanford Company, Richland, Washington.

Hodgson, K. M, M. D. LeClair, and W. W. Schulz, 1996, Work Plan for Defining a Standard Inventory Estimate for Wastes Stored in Hanford Site Underground Tanks, WHC-SD-WM-WP-311, Rev. 1, Westinghouse Hanford Company, Richland, Washington. 
Public Law 101-510, 1990, "Safety Measures for Waste Tanks at Hanford Nuclear Reservation," Section 3137 of National Defense Authorization Act for Fiscal Year 1991.

WHC, 1994, 242-A Evaporator Project for Tanks 102-AW, 103-AP, and 106-AW, WHC-SD-WM-DP-025, Rev. 0-B, Westinghouse Hanford Company, Richland, Washington. 
HNF-SD-WM-ER-359, Rev. 1

\section{APPENDIX A}

\section{HISTORICAL TANK INFORMATION}


HNF-SD-WM-ER-359, Rev. I

This page left blank intentionally. 


\section{APPENDIX A}

\section{HISTORICAL TANK INFORMATION}

Appendix A describes tank 241-AP-103 based on historical information. For this report, historical information includes any information about the fill history, waste types, surveillance, or modeling data about the tank. This information may be useful for supporting or challenging conclusions based on sampling and analysis.

This appendix contains the following information:

- Section A1: Current status of the tank, including the current waste levels.

- Section A2: Information about tank design.

- Section A3: Process knowledge of the tank; i.e., the waste transfer history and the estimated contents of the tank based on modeling data.

- Section A4: Surveillance data for tank 241-AP-103, including surface level readings and temperatures.

- Section A5: References for Appendix A.

\section{A1.0 CURRENT TANK STATUS}

As of August 31, 1996, tank 241-AP-103 contained $87 \mathrm{~kL}$ (23 kgal) of dilute noncomplexed waste (Hanlon 1996). The waste volumes were estimated using a Food Instrument Corporation (FIC) surface level gauge and a manual tape. The volumes of the waste phases found in the tank are shown in Table Al-1.

Tank 241-AP-103 is in service, categorized as sound, and is not on the Watch List. The tank is actively ventilated. 
Table A1-1. Estimated Tank Contents.

\begin{tabular}{|l|c|c|}
\hline & & \\
\hline & 11 & 1 \\
\hline & 87 & 23 \\
\hline Total waste & 83 & 23 \\
\hline Supernatant liquid & 4 & 22 \\
\hline Sludge & 0 & 1 \\
\hline Saltcake & 0 & 0 \\
\hline Drainable interstitial liquid & 83 & 0 \\
\hline Drainable liquid remaining & 83 & 22 \\
\hline Pumpable liquid remaining & & 22 \\
\hline
\end{tabular}

Note:

For definitions and calculation methods refer to Appendix C of Hanlon (1996).

\section{A2.0 TANK DESIGN AND BACKGROUND}

The AP Tank Farm was constructed from 1983 to 1986 in the 200 East Area (Leach and Stahl 1996). The tank farm contains eight double-shell tanks. Each tank has a capacity of $4,390 \mathrm{~kL}(1,160 \mathrm{kgal})$, a diameter of $22.9 \mathrm{~m}(75.0 \mathrm{ft})$, and an operating depth of $10.7 \mathrm{~m}(35.2 \mathrm{ft})$. These tanks were designed to hold concentrated supernatant. The maximum design temperature for liquid storage is $149^{\circ} \mathrm{C}\left(300^{\circ} \mathrm{F}\right)$ (Brevick et al. 1995).

Tank 241-AP-103 was constructed with a primary carbon steel liner (heat-treated and stress-relieved), a secondary carbon steel liner (not heat-treated), and a reinforced concrete shell. The bottom of the primary liner is $13 \mathrm{~mm}(0.5 \mathrm{in}$.) thick, the lower portion of the sides is $19 \mathrm{~mm}(0.75 \mathrm{in}$.) thick, the upper portion of the sides is $13 \mathrm{~mm}(0.5 \mathrm{in}$.) thick, and the dome liner is $9.5 \mathrm{~mm}(0.375 \mathrm{in}$.) thick. The secondary liner is $9.5 \mathrm{~mm}(0.375 \mathrm{in}$.) thick on all sides of the tank. The concrete walls are $460 \mathrm{~mm}(1.5 \mathrm{ft})$ thick and the dome is 380 $\mathrm{mm}(1.25 \mathrm{ft})$ thick. The tank has a flat bottom, where the bottom of the primary and secondary liners are separated by an insulating layer of concrete.

Tank 241-AP-103 has 29 risers ranging in diameter from $100 \mathrm{~mm}(4 \mathrm{in}$.) to $1.1 \mathrm{~m} \mathrm{(42} \mathrm{in.)}$ that provide access to the tank and 42 risers ranging in diameter from $100 \mathrm{~mm}(4 \mathrm{in}$.) to $610 \mathrm{~mm}(24 \mathrm{in}$.) that provide access to the annulus but not to the waste. Table A2-1 shows numbers, diameters, and descriptions of the risers (annular risers not included). A plan view depicting the riser configuration is shown as Figure A2-1. Ten 100-mm (4-in.) diameter risers (three no. 1's. 15, 21, 24, three no. 27's, and no. 28), and three 305-mm (12-inch) diameter risers (two no. 10's, and no. 12), are tentatively available for sampling (Lipnicki 1996). A tank cross section showing the approximate waste level along with a schematic of the tank equipment is in Figure A2-2. 


\begin{tabular}{|c|c|c|c|}
\hline 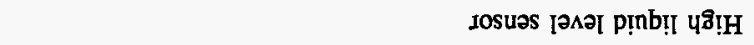 & 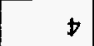 & OI & $\mathfrak{S Z}$ \\
\hline 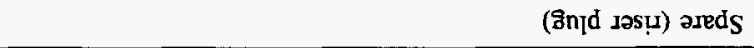 & $t$ & ot & $t z$ \\
\hline 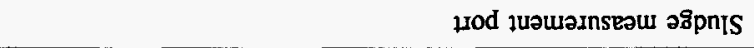 & $\downarrow$ & OI & $z z$ \\
\hline 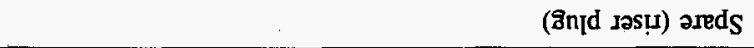 & $t$ & OI & I \\
\hline 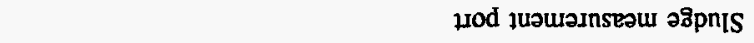 & $z \mathrm{I}$ & $O \mathcal{E}$ & 9I \\
\hline 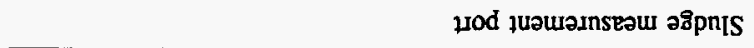 & ZI & $0 \mathcal{E}$ & 9 I \\
\hline 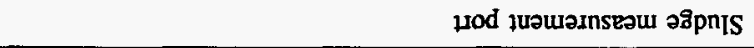 & ZI & $0 \mathcal{E}$ & 9 I \\
\hline (8ిnId des!̣) areds & $\downarrow$ & OI & SI \\
\hline 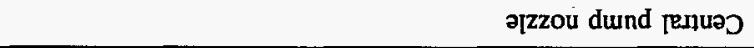 & 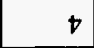 & OI & tI \\
\hline annssəId Yure $L$ & ZI & $0 \mathcal{E}$ & $\varepsilon \mathrm{I}$ \\
\hline əreds - Hod uoṭenasqO & $2 \mathrm{II}$ & $O E$ & ZI \\
\hline (ł!̣d dund [enuəs) sołnqụ]s!p KunIS & $z t$ & OII & II \\
\hline (Innd Iəsu) areds & $Z \mathbf{I I}$ & $O E$ & OI \\
\hline (anyd Iəș) areds & $Z I$ & $0 \varepsilon$ & OI \\
\hline 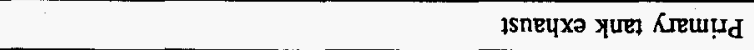 & ZI & $0 \mathcal{E}$ & $L$ \\
\hline (8njd Iəs!) วreds & ZI & $0 \varepsilon$ & $L$ \\
\hline 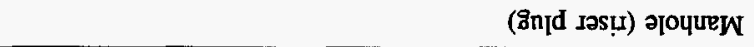 & $z t$ & OI I & $\mathfrak{S}$ \\
\hline (8ిn]d دәsழ़) әрочนеW & $z t$ & OII & 列 \\
\hline әqoId ә[dnosourəપ.L & ZI & $0 \varepsilon$ & $\downarrow$ \\
\hline (1țd dund [enues) dund jurequeradns & $2 \mathrm{I}$ & OE & $\varepsilon$ \\
\hline 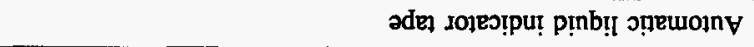 & $\downarrow$ & OI & $\tau$ \\
\hline 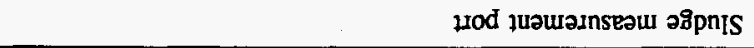 & $\downarrow$ & $0 \mathrm{I}$ & I \\
\hline 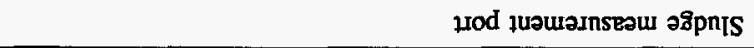 & 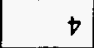 & ol & I \\
\hline นod นนวนวมnsEอน วริpกIS & $\nabla$ & OI & I \\
\hline (3) & (1) & 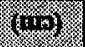 & \multirow{2}{*}{$\sin ^{2}$} \\
\hline F小 & \multicolumn{2}{|c|}{ 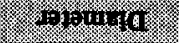 } & \\
\hline
\end{tabular}

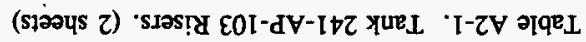


Table A2-1. Tank 241-AP-103 Risers. (2 sheets)

\begin{tabular}{|c|c|c|c|}
\hline (1) & 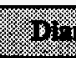 & 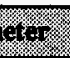 & \\
\hline Vinging & $(6,1)$ & $(8,9$ & 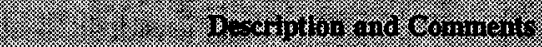 \\
\hline 26 & 10 & 4 & Liquid level indicator \\
\hline 27 & 10 & 4 & Spare (riser plug) \\
\hline 27 & 10 & 4 & Spare (riser plug) \\
\hline 27 & 10 & 4 & Spare (riser plug) \\
\hline 28 & 10 & 4 & Spare (riser plug) \\
\hline
\end{tabular}

Note:

Brevick et al. (1995) and Salazar (1994) 
Figure A2-1. Riser Configuration for Tank 241-AP-103.

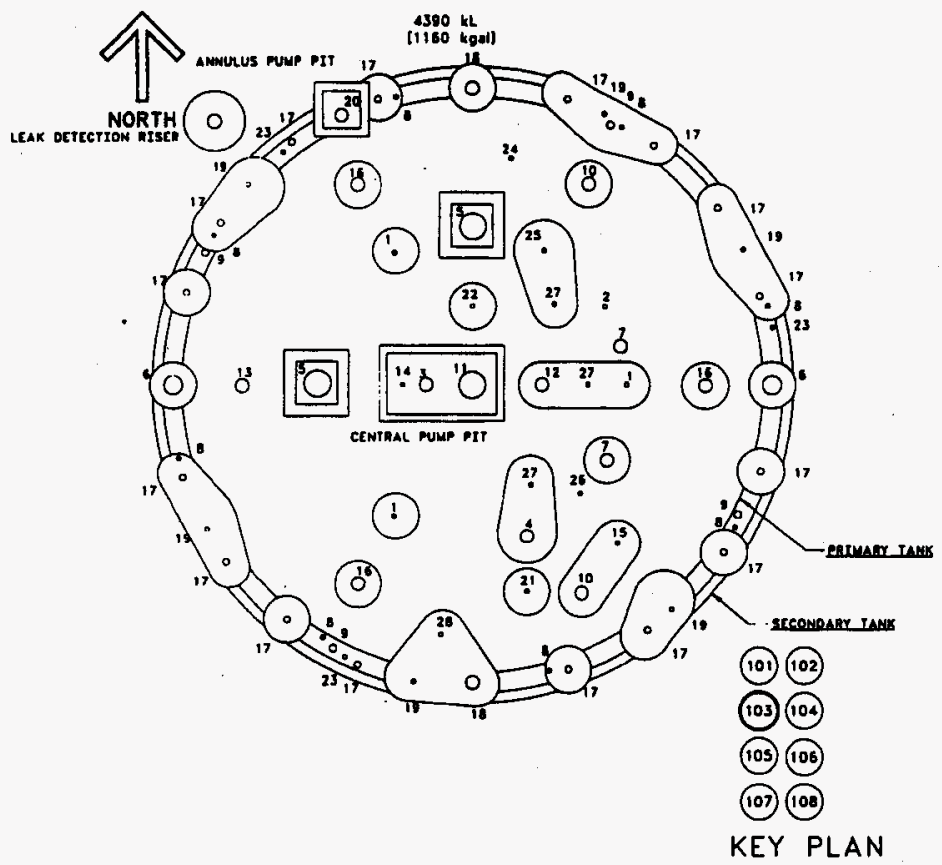


Figure A2-2. Tank 241-AP-103 Cross Section and Schematic.

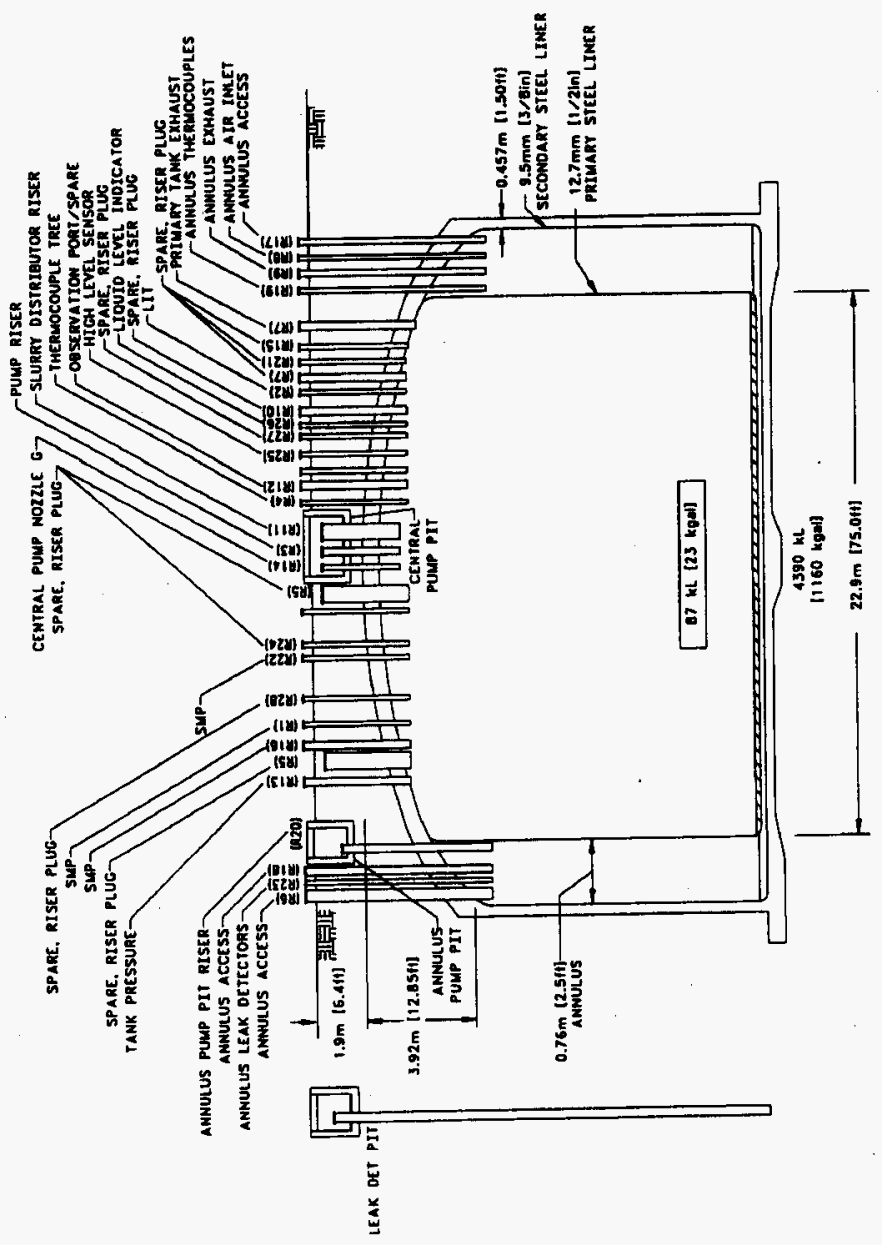




\section{A3.0 PROCESS KNOWLEDGE}

The sections below: 1) provide information about the transfer history of tank 241-AP-103; 2) describe the process wastes that made up the transfers; and 3) give an estimate of the current tank contents based on transfer history.

\section{A3.1 WASTE TRANSFER HISTORY}

Table A3-1 summarizes the waste transfer history of tank 241-AP-103 (Agnew et al. 1996b). The tank was brought into service during the third quarter of 1986 with the addition of about $95 \mathrm{~kL}$ (25 kgal) of flush water from miscellaneous sources. The next transfer was not received until the first quarter of 1988 when the tank received the first of a series of PUREX ammonia scrubber feed (PASF) from the PUREX Plant. During the first half of 1988 , tank 241-AP-103 received a total of 3,676 kL (971 kgal) of PASF, $375 \mathrm{~kL}$ (99 gal) of wash from tank 241-AW-102, and $53 \mathrm{~kL}$ (14 kgal) of flush water.

During the third quarter of 1988 the tank received $367 \mathrm{~kL}(97 \mathrm{kgal})$ of PASF and $38 \mathrm{~kL}$ (10 kgal) of flush water. All but $83 \mathrm{~kL}$ of the waste was transferred to tank $241-\mathrm{AW}-102$ for processing in the evaporator (tank 241-AW-102 is the feed tank for the 242-A Evaporator). In the fourth quarter of 1988 tank 241-AP-103 received 2,190 kL (578 kgal) of PASF from tank 241-AP-101. The next major transfer occurred during the fourth quarter of 1989 when $2,330 \mathrm{~kL}(616 \mathrm{kgal})$ of waste were sent to tank $241-\mathrm{AP}-101$.

Major transfers from the fourth quarter of 1989 through the second quarter of 1991 for tank 241-AP-103 consisted of $4,212 \mathrm{~kL}(1,113 \mathrm{kgal})$ of dilute noncomplexed waste from tank 241-AY-102.

The waste in tank 241-AP-103 was selected for concentration as part of 242-A Evaporator Campaign 94-1 (Guthrie 1994). During April and May 1994, about 4,170 kL (1,102 kgal) of waste was transferred to tank 241-AW-102. No further waste transfers have been made into or out of the tank. 
Table A3-1. Summary of Tank 241-AP-103 Major Waste Transfers.

\begin{tabular}{|c|c|c|c|c|c|}
\hline \multirow{2}{*}{ Monices } & \multirow{2}{*}{ (4) } & \multirow[b]{2}{*}{ 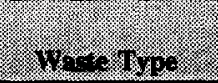 } & \multirow{2}{*}{ 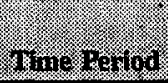 } & \multicolumn{2}{|c|}{ 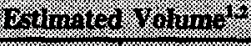 } \\
\hline & & & & 1 & 818 \\
\hline $\begin{array}{l}\text { Miscellaneous } \\
\text { sources }\end{array}$ & & Flush water & $1986-1988$ & 329 & 87 \\
\hline PUREX Plant & & $\begin{array}{l}\text { PUREX ammonia } \\
\text { scrubber feed }\end{array}$ & 1988 & 4,042 & 1,068 \\
\hline $241-A W-102$ & & Supernatant & 1988 & 375 & 99 \\
\hline & 241-AW-102 & Supernatant & 1988 & $-4,512$ & $-1,192$ \\
\hline 241-AP-101 & & $\begin{array}{l}\text { PUREX ammonia } \\
\text { scrubber feed and } \\
\text { water }\end{array}$ & 1988 & 2,190 . & 578 \\
\hline & 241-AP-101 & Supernatant & 1989 & $-2,330$ & -616 \\
\hline 241-AY-102 & & $\begin{array}{l}\text { Dilute } \\
\text { noncomplexed } \\
\text { waste from } \\
\text { various sources } \\
\text { and aging waste } \\
\text { condensate }\end{array}$ & $1989-1991$ & 4,212 & 1,113 \\
\hline & 241-AW-102 & Supernatant & 1994 & $-4,170^{3}$ & $-1,102^{3}$ \\
\hline
\end{tabular}

Notes:

'Unless otherwise noted, data are derived from Agnew et al. (1996b).

${ }^{2}$ Because only major transfers are listed, the sum of these transfers will not equal the current waste volume.

${ }^{3}$ Derived from unvalidated data taken from the Operational Waste Volume Projection database.

\section{A3.2 HISTORICAL ESTIMATION OF TANK CONTENTS}

This section provides an estimate of the contents of tank 241-AP-103 based on historical transfer data presented in the Waste Status and Transaction Record Summary (Agnew et al. 1996b) and in the Hanford Tank Chemical and Radionuclide Inventories: Hanford Defined Wastes (HDW) Model Rev. 3 (Agnew et al. 1996a). The HDW model is composed of three parts: 1) a combination of process information and transaction information to derive compositions for about 50 Hanford Defined Wastes, each of which has both solid and supernatant layers; 2) a derivation of solids histories for each tank, called the Tank Layer 
Model, that is based on the nonevaporator related primary additions of waste; and 3) a weighted percentage calculation of supernatant blending and saltcake content called the Supernatant Mixing Model.

This information is combined in a spreadsheet to produce the historical inventory estimates for each of the 177 tanks. These predictions have not been validated and should be used with caution. In some cases, the available data are incomplete, thus reducing the reliability of the transfer data and the modeling results derived from them. These predictions can only be considered estimates that require further evaluation using analytical data.

The historical inventory estimate for tank 241-AP-103 defines the tank waste as consisting of $4,277 \mathrm{~kL}(1,130 \mathrm{kgal})$ of supernatant. Tank $241-\mathrm{AP}-103$ has been involved in several tank-to-tank transfers since the historical end date of the Waste Status and Transaction Summary data of January 1, 1994.

Table A3-2 shows the historical inventory estimate of the expected waste constituents and concentrations of tank 241-AP-103 as of January 1, 1994 (Agnew 1996b). Figure A3-1 shows a graphical representation of the current estimated waste type and volume. 


\begin{tabular}{|c|c|c|c|}
\hline $06 t^{6} I$ & $\Rightarrow z \varepsilon$ & $\forall 210.0$ & $\left(z^{E} \mathrm{O} ! S \mathrm{se}\right) ! S$ \\
\hline $05 t^{4} 8$ & $0+8^{4} \mathrm{I}$ & $9020^{\circ} 0$ & $z^{t} \mathrm{OS}$ \\
\hline $0 \mathrm{It} t^{6} \mathrm{Z}$ & S2S & 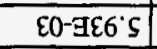 & $-\varepsilon \mathrm{Od}$ \\
\hline $10+30 L \cdot z$ & $086^{\prime} \mathrm{s}$ & $\angle O T^{\circ} 0$ & $z_{-8}^{6} \mathrm{OJ}$ \\
\hline $50+\exists E Z^{\circ} I$ & $089^{\prime} \mathrm{Z}$ & $\nabla 290^{\circ} 0$ &. $\mathrm{ON}$ \\
\hline $\mathrm{SO}+380^{\circ} \mathrm{z}$ & $t 0+\exists \varepsilon+s$ & $28 L^{\circ} 0$ &. $\mathrm{ON}$ \\
\hline t0+788.9 & to+BOS'i & $s+60^{\circ} 0$ &. $\mathrm{HO}$ \\
\hline $009^{\prime} \mathrm{I}$ & $8+\varepsilon$ & $\varepsilon 0-3 \varepsilon S^{\circ} 6$ & $+\mathrm{X}$ \\
\hline $060^{\circ} \mathrm{I}$ & $\angle \varepsilon Z$ & $\varepsilon 0-\exists t \varepsilon^{\circ} 9$ & $+z^{\mathrm{ED}}$ \\
\hline 799 & I.OI & t0-a $\angle 6^{\circ} \mathrm{I}$ & ${ }_{+}+\mathrm{WW}$ \\
\hline$\varepsilon+20^{\circ} 0$ & $\varepsilon 0-3 I \varepsilon^{\circ} \varsigma$ & $80-360^{\circ} 9$ & $+\tau^{2} \mathbf{S}$ \\
\hline$\$ 82$ & $2 \cdot 29$ & EO-GEI'I & $+2 \mathrm{~W}$ \\
\hline$\angle L: 8$ & $16^{\circ} 1$ & $90-368 \cdot 6$ & $+29 d$ \\
\hline $0.8 \mathrm{I}$ & $26 \cdot \varepsilon$ & $50-319^{\circ} t$ & $\left({ }^{2}(\mathrm{HO}) \mathrm{O} \mathrm{Z} \mathrm{SE}\right) \mathrm{JZ}$ \\
\hline SLI'0. & $28 \varepsilon 0^{\circ} 0$ & $\angle 0^{-3}+0^{\circ} \mathrm{Z}$ & $+z^{8} \mathrm{H}$ \\
\hline $9 I I 0$ & $2 S z 0^{\circ} 0$ & $\angle 0-3 S 6^{\circ} \mathrm{I}$ & $+\varepsilon^{8 T}$ \\
\hline $26 . \mathrm{L}$ & $E L^{\prime} \mathrm{I}$ & $90-358.8$ & $+\varepsilon ! \mathrm{g}$ \\
\hline$L 6 S$ & OEI & $\varepsilon 0-389^{\circ} \tau$ & $+\varepsilon^{15}$ \\
\hline LEE & $D^{\circ} \varepsilon L$ & 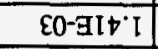 & 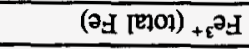 \\
\hline$t 0+3 S \varepsilon^{\prime} z$ & OEI's & tor:0 & $+\mathrm{e} I \mathrm{~V}$ \\
\hline so+ $\mathrm{BZS}^{\prime} \mathrm{I}$ & $t 0+\exists Z \varepsilon^{\prime} \varepsilon$ & SS I I & $+{ }_{+}^{\mathrm{EN}}$ \\
\hline (2) & (191: & 2 & 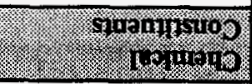 \\
\hline & & $26 I^{\circ} 0$ & $z_{2}(1 D M) ~ \supset \%$ IM JOL \\
\hline & & 2.88 & 2\%1M IәTEM \\
\hline & & $(\mathrm{Tu} / \mathrm{g}) \angle 0^{\circ} \mathrm{I}$ & 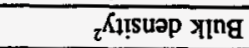 \\
\hline & \multicolumn{2}{|c|}{ 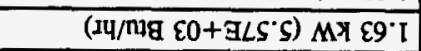 } & peOI 1EכH \\
\hline & \multicolumn{2}{|c|}{ 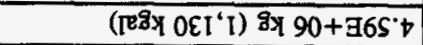 } & गISEM [EIOL \\
\hline 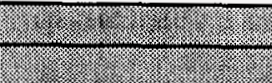 & 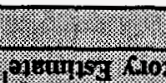 & $\frac{20.8}{101}$ & 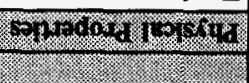 \\
\hline
\end{tabular}

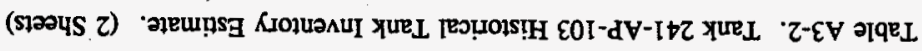




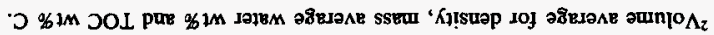

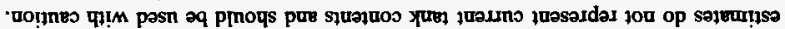

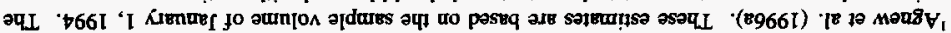

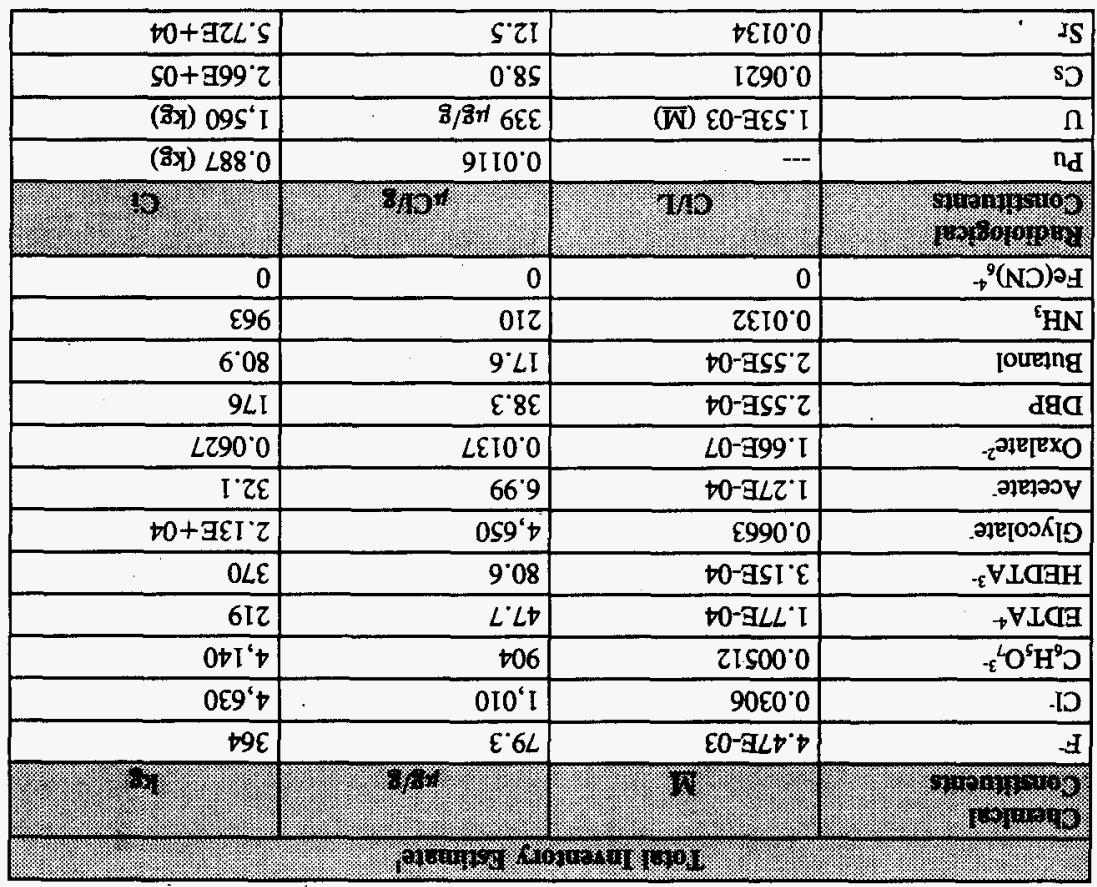

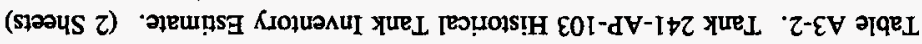


Figure A3-1. Tank Layer Model for Tank 241-AP-103.

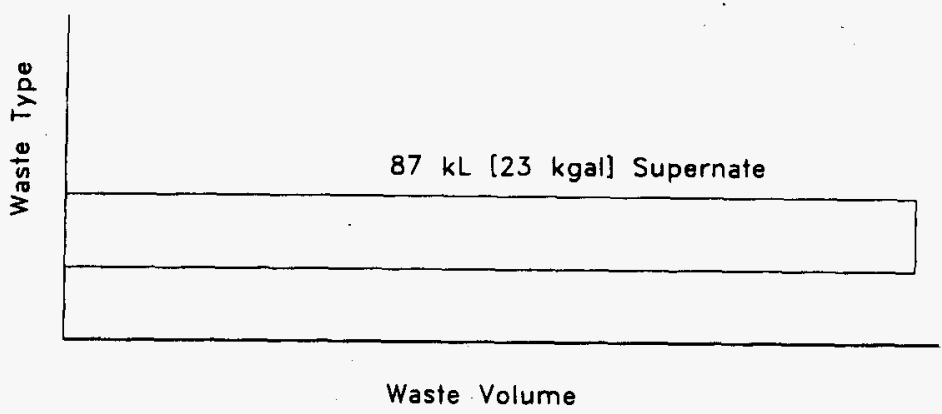

\section{A4.0 SURVEILLANCE DATA}

Tank 241-AP-103 surveillance data consist of surface level measurements (liquid and solid), temperature monitoring inside the tank (waste and vapor space), and leak detection well monitoring for radioactive liquids outside the primary tank. Surveillance data provide the basis for determining tank integrity.

\section{A4.1 SURFACE LEVEL READINGS}

Waste surface level monitoring in tank 241-AP-103 is performed with an FIC gauge in riser 2 and a manual tape in riser 26. A manual tape is used when the FIC is out of service. Because this is an active tank, the surface level is continually subject to change. The waste surface level measured on September 20, 1996 with the FIC was $213 \mathrm{~mm}$ (8.4 in.), which equals about $87.4 \mathrm{~kL}(23.1 \mathrm{kgal}$ ) (Hanion 1996). A graphical representation of the volume measurements is presented as a level history graph in Figure A4-1. The level measured was $203 \mathrm{~mm}(8 \mathrm{in}$.) using the manual tape.

\section{A4.2 INTERNAL TANK TEMPERATURES}

In-tank temperature data for tank 241-AP-103 are recorded by 18 thermocouples on one thermocouple tree located in riser 4. Data are recorded weekly (Tran 1993). The minimum temperature on September 16,1996 , was $18.7^{\circ} \mathrm{C}\left(65.7^{\circ} \mathrm{F}\right)$ on thermocouple 17 ; the maximum temperature on the same date was $19.3^{\circ} \mathrm{C}\left(66.8^{\circ} \mathrm{F}\right)$ on thermocouple 1 . 
Temperature data were evaluated from the Computer Automated Surveillance System (Brevick et al. 1995) recorded from April 1986 to March 1995 (for all 18 thermocouples) and from the Surveillance Analysis Computer System (SACS) recorded from July 1989 to September 16, 1996 (for 12 of the thermocouples). Not all 12 thermocouples have data covering the entire period. From the data available in SACS, the average temperature between July 1989 and September 16,1996 was $16^{\circ} \mathrm{C}\left(60^{\circ} \mathrm{F}\right)$ with a minimum of $7.8^{\circ} \mathrm{C}$ $\left(46^{\circ} \mathrm{F}\right)$ and a maximum of $23^{\circ} \mathrm{C}\left(74^{\circ} \mathrm{F}\right)$.

A graph of the weekly high temperatures can be found in Figure A4-2.

\section{A4.3 TANK 241-AP-103 PHOTOGRAPHS}

No interior photographs are available for this tank. 
Figure A4-1. Tank 241-AP-103 Level History.

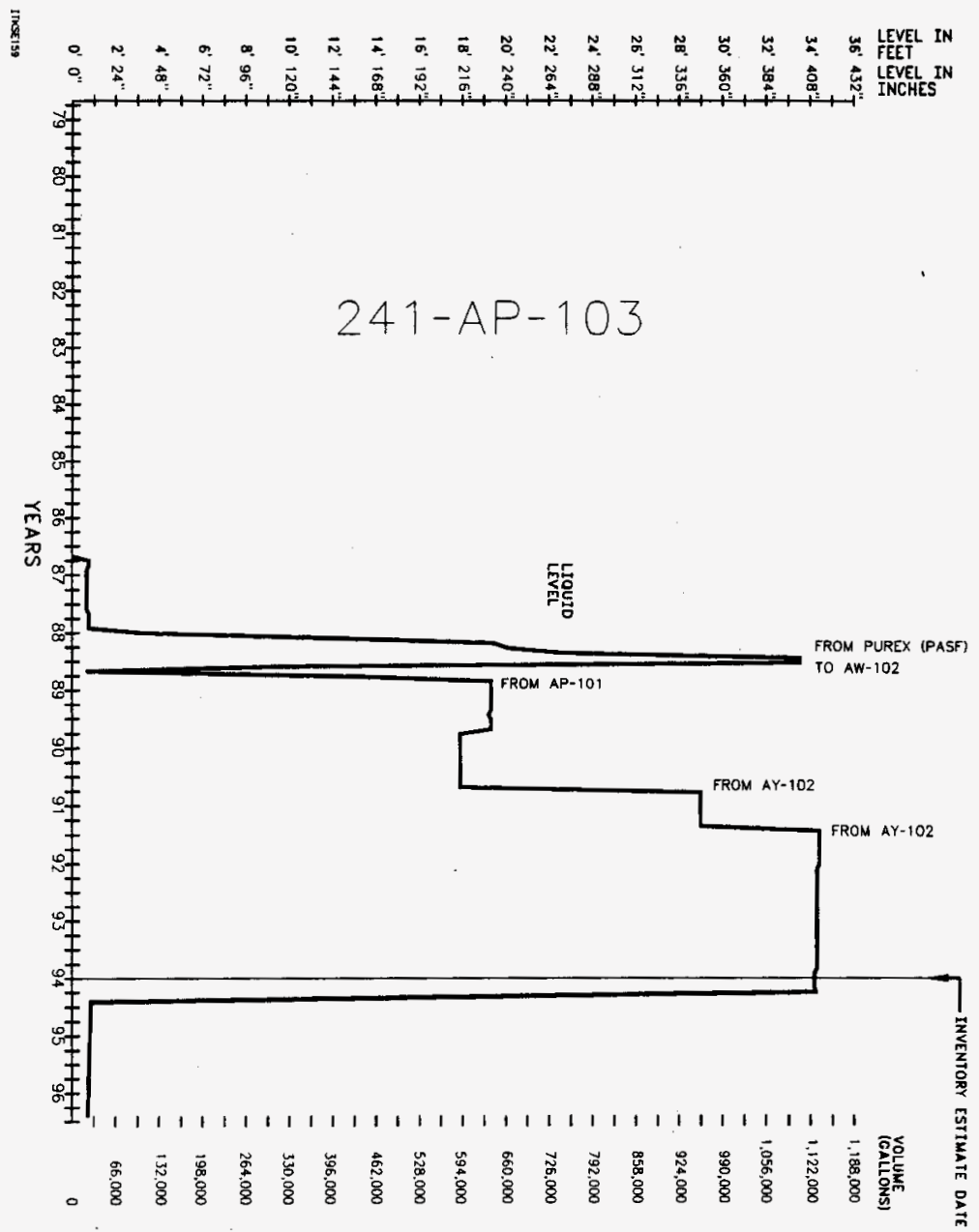


HNF-SD-WM-ER-359, Rev. 1

Figure A4-2. Tank 241-AP-103 Weekly High Temperature Plot.

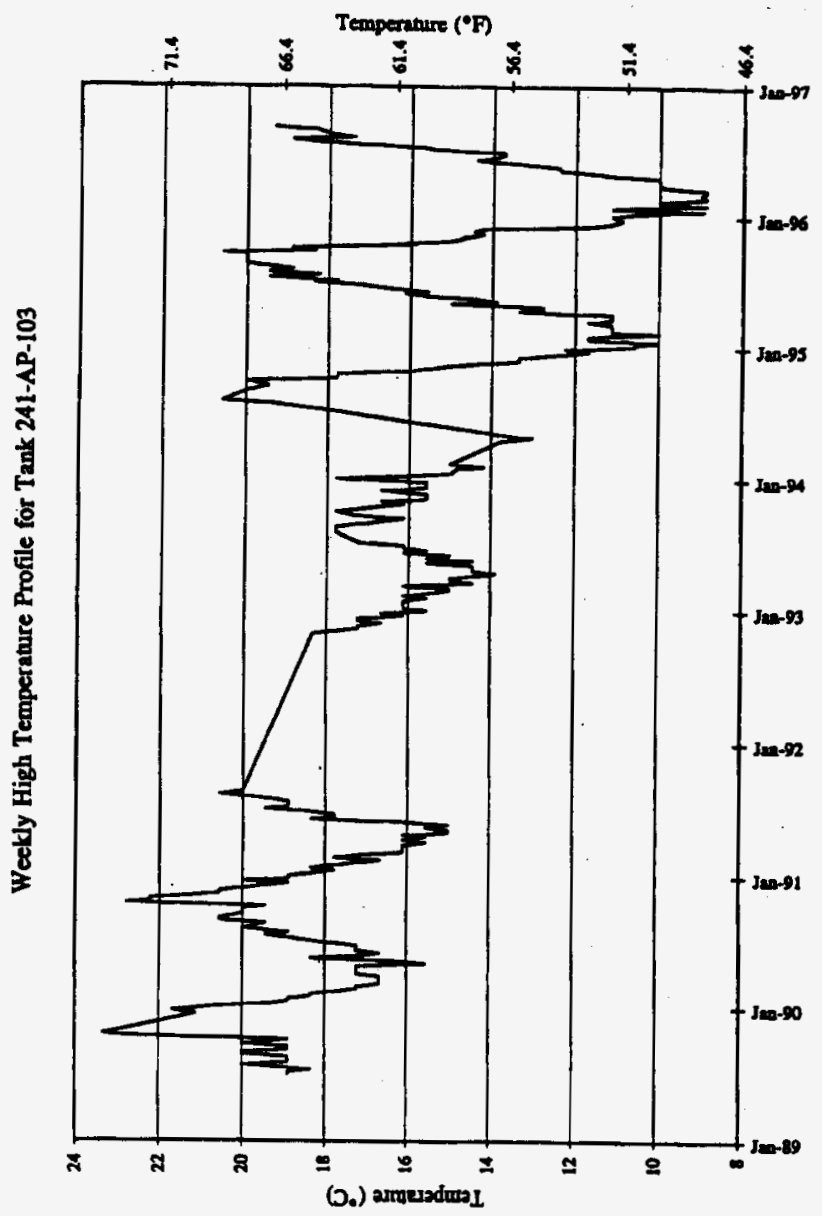




\section{A5.0 APPENDIX A REFERENCES}

Agnew, S. F., J. Boyer, R. A. Corbin, T. B. Duran, J. R. Fitzpatrick, K. A: Jurgensen, T. P. Ortiz, and B. L. Young, 1996a, Hanford Tank Chemical and Radionuclide Inventories: HDW Model Rev. 3, LA-UR-96-858, Rev. 0, Los Alamos National Laboratory, Los Alamos, New Mexico.

Agnew, S. F., P. Baca, R. A. Corbin, T. B. Duran and K. A. Jurgensen, 1996b, Waste Status and Transaction Record Summary for the Southeast Quadrant, WHC-SD-WM-TI-689, Rev. 1, Westinghouse Hanford Company, Richland, Washington.

Brevick, C. H., L. A. Gaddis, and S. D. Consort, 1995, Supporting Document for the Southeast Quadrant Historical Tank Content Estimate for AP Tank Farm, WHC-SD-WM-ER-315, Rev. 0, Westinghouse Hanford Company, Richland, Washington.

Guthrie, M. D., 1994, 242-A Campaign 94-1 Post Run Document, WHC-SD-WM-PE-053, Rev. 0, Westinghouse Hanford Company, Richland, Washington.

Hanlon, B. M., 1996, Waste Tank Summary Report for Month Ending August 31, 1996, WHC-EP-0182-100, Westinghouse Hanford Company, Richland, Washington.

Leach, C. E. and S. M. Stahl, 1996, Hanford Site Tank Farm Facilities Interim Safety Basis Volume $I$ and II, WHC-SD-WM-ISB-001, Rev. 0-B, Westinghouse Hanford Company, Richland, Washington.

Lipnicki, J., 1996, Waste Tank Risers Available for Sampling, WHC-SD-WM-TI-710, Rev. 3, Westinghouse Hanford Company, Richland, Washington.

Salazar, B. E., 1994, Double-Shell Underground Waste Storage Tanks Riser Survey, WHC-SD-RE-TI-093, Rey. 4, Westinghouse Hanford Company, Richland, Washington.

Tran, T. T., 1993, Thermocouple Status Single-Shell \& Double-Shell Waste Tanks, WHC-SD-WM-TI-553, Rev. 0, Westinghouse Hanford Company, Richland, Washington. 
HNF-SD-WM-ER-359, Rev. 1

\section{APPENDIX B}

SAMPLING OF TANK 241-AP-103 
HNF-SD-WM-ER-359, Rev. 1

This page left blank intentionally. 


\section{APPENDIX B}

\section{SAMPLING OF TANK 241-AP-103}

Appendix B provides sampling and analysis information for each known sampling event for tank 241-AP-103 and provides an assessment of the grab sample results.

- Section B1: Tank Sampling Overview

- Section B2: Analytical Results

- Section B3: Assessment of Characterization Results

- Section B4: References for Appendix B.

Future sampling of tank 241-AP-103 will be appended to the above list.

\section{B1.0 TANK SAMPLING OVERVIEW}

This section describes the September through November 1991 sampling and analysis event for tank 241-AP-103. These grab samples were taken and analyzed in accordance with Double-Shell Tank Waste Analysis Plan (Halgren 1991). Further discussions of the sampling and analysis procedures can be found in the Tank Characterization Reference Guide (DeLorenzo et al. 1994).

Section B1.4 presents results from grab samples obtained in support of 242-A Evaporator campaign 94-1. The AP-103 grab sample was mixed with AW-102 and AW-106 grab samples. Hence, results are presented for information only.

\section{B1.1 DESCRIPTION OF SAMPLING EVENT}

Tank 241-AP-103 was sampled on September 19 and 24, October 9, and November 25, 1991. The waste analysis plan (Halgren 1991) states that samples are to be collected from three risers. A total of ten samples (nine samples and a duplicate) were taken from risers 1, 27 , and 28 . Because the tank waste may stratify vertically, the analysis plan divides each tank into top, middle, and bottom vertical layers with samples taken from each layer. The "bottle-on-a-string" method (ASTM 1973) was used to collect the samples from the tank. Each glass sample bottle collected approximately $100 \mathrm{~mL}$ of liquid.

All analyses were performed by the Westinghouse Hanford Company 222-S Laboratory. 
Table B1-1 summarizes the sample location (riser number), sample numbering, and date sampled information.

Table B1-1. Tank 241-AP-103 Sample Information.

\begin{tabular}{|c|c|c|c|c|}
\hline 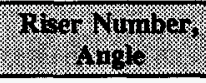 & (Simple Bure & B. & 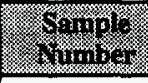 & 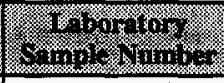 \\
\hline \multirow[t]{3}{*}{$1,330^{\circ}$} & \multirow[t]{3}{*}{ 9-19-91 } & 398 & 3AP891-1 & R933 \\
\hline & & 182 & 3AP891-2 & R934 \\
\hline & & 26 & 3AP891-3 & R935 \\
\hline \multirow[t]{4}{*}{$27,90^{\circ}$} & \multirow[t]{4}{*}{$9-24-91$} & 338 & 3AP891-4 & R936 \\
\hline & & 194 & 3AP891-5 & R937 \\
\hline & & 194 & 3AP891-6 & R941 \\
\hline & & 122 & 3AP891-7 & R942 \\
\hline \multirow[t]{3}{*}{$28,187^{\circ}$} & \multirow[t]{3}{*}{$10-9-91$} & 398 & 3AP891-8 & R943 \\
\hline & & 218 & 3AP891-9 & R944 \\
\hline & & 98 & 3AP891-10 & R945 \\
\hline Composite & $-\cdots$ & $-\ldots$ & $\ldots$ & R949 \\
\hline
\end{tabular}

Note:

'Sample 3AP891-3 was resampled (11-25-91) and replaced by sample 3AP1191-1 due to the custody seal being improperly attached.

\section{B1.2 SAMPLE HANDLING}

Tank 241-AP-103 was sampled between September 19 and November 25, 1991. The analyses of the samples by the laboratory occurred between the last quarter of 1991 and first quarter of 1992. Samples were not preserved (acidification or refrigeration) at the time of sampling. According to the data validation report, the maximum holding times for both the volatile and semivolatile organic analyses were exceeded for all samples. The violation of recommended holding times for these analyses was not expected to substantially affect the data (see Section B2.6 for further discussion).

Descriptions of the waste samples were very difficult to locate. For samples R933, R934, R935, and R936, the Extraction Log Book stated they were all a "clear liquid." No other descriptions about the samples were found. 


\section{B1.3 SAMPLE ANALYSIS}

All reported analyses were performed in accordance with approved laboratory procedures. The analyses performed on the grab samples were those required by the waste analysis plan (Halgren 1991), and are listed in Table B1-2. Table B1-3 displays the analytical procedures by title and number. No deviations or modifications were noted by the laboratory.

A limited amount of quality control (QC) data was available for tank 241-AP-103. Duplicate analyses were performed on samples R933, R941, and R949. Spike analyses were run on R933. Check standards were evaluated before and after each evaluation in order to verify instrument calibration and analytical performance. An assessment of the QC procedures and data is presented in Section B3.2 of this report.

Table B1-2. Summary of Samples and Requested Analytes.

\begin{tabular}{|c|c|c|}
\hline SAmple Yininer & $\begin{array}{l}\text { Whowhow Sample } \\
\text { numbers }\end{array}$ & 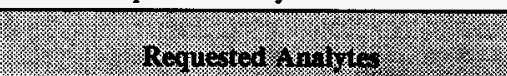 \\
\hline 3AP1191-1 & R935 & \multirow{11}{*}{ 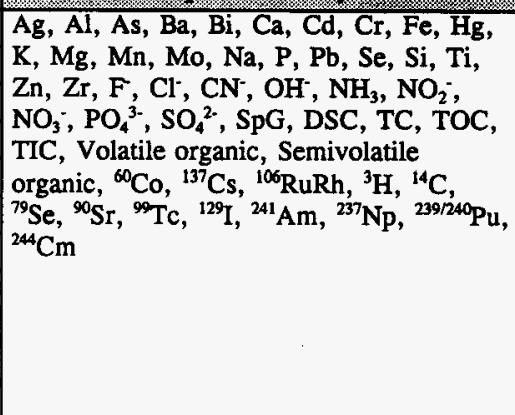 } \\
\hline 3AP891-1 & R933 & \\
\hline 3AP891-2 & R934 & \\
\hline 3AP891-4 & R936 & \\
\hline 3AP891-5 & R937 & \\
\hline 3AP891-6 & R941 & \\
\hline 3AP891-7 & $\overline{\mathrm{R} 942}$ & \\
\hline 3AP891-8 & R943 & \\
\hline 3AP891-9 & $\overline{R 944}$ & \\
\hline 3AP891-10 & R945 & \\
\hline Composite & R949 & \\
\hline
\end{tabular}


Table B1-3. General Analytical Methods.

\begin{tabular}{|c|c|c|}
\hline ো & (3) & 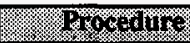 \\
\hline $\mathrm{F}^{-}, \mathrm{Cl}^{-}, \mathrm{NO}_{2}^{-}, \mathrm{NO}_{3}^{-}, \mathrm{SO}_{4}{ }^{2-}, \mathrm{PO}_{4}{ }^{3-}$ & Ion Chromatography & LA-533-105 \\
\hline $\mathrm{NH}_{3}$ & Kjeldahl & LA-634-102 \\
\hline $\mathrm{OH}^{-}$ & Titration & LA-661-102 \\
\hline $\mathrm{CN}^{-}$ & Distillation/Spectrometric Analysis & LA-695-101 \\
\hline TIC & $\begin{array}{l}\text { Acidification followed by } \mathrm{CO}_{2} \\
\text { detection }\end{array}$ & LA-622-102 \\
\hline TOC & $\begin{array}{l}\text { Combustion } / \mathrm{CO}_{2} \text { detection by } \\
\text { coulometry }\end{array}$ & LA-344-105 \\
\hline Total U & Alpha proportional counting & LA-508-101 \\
\hline $\begin{array}{l}\text { As } \\
\text { Se }\end{array}$ & $\mathrm{GHAA}^{2}$ & $\begin{array}{l}\text { LA-355-131 } \\
\text { LA-362-131 }\end{array}$ \\
\hline $\mathrm{Hg}$ & $\mathrm{CVAA}^{3}$ & LA-325-102 \\
\hline Total Metals & $\mathrm{ICP}^{\top}$ & LA-505-151 \\
\hline $\begin{array}{l}{ }^{134} \mathrm{Cs},{ }^{137} \mathrm{Cs},{ }^{94} \mathrm{Nb},{ }^{160} \mathrm{RuRh}, \\
{ }^{95} \mathrm{Nb},{ }^{144} \mathrm{CePr},{ }^{60} \mathrm{Co},{ }^{154 / 55} \mathrm{Eu} \text {, } \\
{ }^{226} \mathrm{Ra},{ }^{113} \mathrm{Sn}\end{array}$ & Gamma energy analysis & LA-548-121 \\
\hline${ }^{3} \mathrm{H}$ & Liquid scintillation & $\begin{array}{l}\text { LA-218-114 } \\
\text { LA-348-104 }\end{array}$ \\
\hline${ }^{79} \mathrm{Se}$ & Liquid scintillation & $\begin{array}{l}\text { LA-365-131 } \\
\text { LA-438-101 }\end{array}$ \\
\hline${ }^{90} \mathrm{Sr}$ & Separation $/$ Beta $^{5}$ & LA-220-101 \\
\hline${ }^{129} \mathrm{I}$ & Low energy gamma analysis & LA-378-103 \\
\hline${ }^{237} \mathrm{~Np}$ & Extraction/Alpha ${ }^{6}$ & LA-933-141 \\
\hline $\begin{array}{l}{ }^{239 / 240} \mathrm{Pu},{ }^{24 /} \mathrm{Am}, \\
{ }^{234 / 235} \mathrm{U},{ }^{238} \mathrm{U}\end{array}$ & Separation/AEA ${ }^{\top}$ & LA-503-156 \\
\hline Specific gravity & Direct & LA-510-112 \\
\hline Energetics & Differential scanning calorimetry & LA-514-113 \\
\hline $\begin{array}{l}\text { Volatile organic } \\
\text { Semivolatile organic }\end{array}$ & $\begin{array}{l}\text { Gas chromatography/mass } \\
\text { spectroscopy }\end{array}$ & SW-846,8240 \\
\hline
\end{tabular}

Notes:

'Ammonia analysis by caustic addition, distillation, and capture in a boric acid solution.

${ }^{2}$ Gaseous hydride atomic absorption

${ }^{3}$ Cold vapor atomic absorption

"Inductively coupled plasma

${ }^{\text {s}}$ Chemical separation along with beta proportional counting

'Extraction followed by alpha proportional counting

${ }^{7}$ Chemical separation followed by alpba energy analysis 


\section{B1.4 1994 EVAPORATOR CAMPAIGN GRAB SAMPLE}

Grab samples were taken from three tanks in May 1994 (241-AP-107, 241-AW-102, 241-AW-106) and composited for analysis in support of the 242-A Evaporator 94-1 campaign. Analysis for semivolatile organic constituents were performed using EPA SW-846-based methodology. The samples were submitted to the 222-S Laboratory on May 5, 1994. All of the semivolatile constituents analyzed were below analytical detection levels and the quantitation limit of $1,000 \mu \mathrm{g} / \mathrm{L}$ except for tributyl phosphate, which had a concentration of $1,600 \mu \mathrm{g} / \mathrm{L}$ (Wehner 1994).

\section{B1.5 DESCRIPTION OF HISTORICAL SAMPLING EVENT}

Prior to the 1991 sampling event, the last sampling of tank 241-AP-103 occurred in April 1988. Because multiple waste transfers occurred since this last sampling event, no valid comparison between the sampling events can be made, and the data are not presented in this report.

\section{B2.0 ANALYTICAL RESULTS}

\section{B2.1 OVERVIEW}

This section summarizes the sampling and analytical results associated with the 1991 grab sampling and analysis of tank 241-AP-103. The chemical, radiochemical, physical, and organic results associated with tank 241-AP-103 are presented within this document as indicated in Table B2-1. These results are documented in WHC (1992).

Table B2-1. Analytical Presentation Tables.

\begin{tabular}{|l|l|}
\hline Summary data for inorganic analyses & \multicolumn{1}{|c|}{ (1) } \\
\hline Summary data for organic analyses & B2-2 through B2-24 \\
\hline Summary data for radiochemical analyses & B2-25 through B2-30 \\
\hline $\begin{array}{l}\text { Specific gravity } \\
\begin{array}{l}\text { Summary data for volatile and semivolatile organic } \\
\text { analyses }\end{array}\end{array}$ & B2-31 through B2-54 \\
\hline
\end{tabular}


The four QC parameters assessed in conjunction with the tank 241-AP-103 samples were standard recoveries, spike recoveries, duplicate analyses, and blanks. The QC criteria applied to the data were 75 to 125 percent recovery for standards, 75 to 125 percent recovery for spikes and $\leq 20$ percent for the relative percent difference (RPD) between duplicates. These criteria applied to all of the analytes. The only QC parameter for which limits are not specified is blank contamination. The limits for blanks are set forth in guidelines followed by the laboratory, and all data results presented in this report have met those guidelines. Sample and duplicate pairs in which any of the QC parameters were outside of these limits are footnoted in the sample mean column of the following data summary tables with an $a, b, c, d, e$, or $f$ as follows:

- $\quad \mathrm{a}$ " indicates that the standard recovery was below the QC limit.

- "b" indicates that the standard recovery was above the QC limit.

- $\quad c "$ indicates that the spike recovery was below the QC limit.

- $\quad \mathrm{d}$ " indicates that the spike recovery was above the QC limit.

- $\quad \mathrm{e}$ " indicates that the RPD was above the QC limit.

- $\quad \mathrm{f}$ " indicates blank contamination.

\section{B2.2 INORGANIC ANALYSES}

The following sections discuss the types of inorganic analyses performed and results. General QC requirements and results are discussed in Section B3.2.

\section{B2.2.1 Inductively Coupled Plasma Spectroscopy}

The following analytes were analyzed according to procedure LA-505-151: aluminum, barium, cadmium, chromium, iron, lead, magnesium, manganese, silver, sodium and zinc. Aluminum and sodium were the most abundant metals in tank 241-AP-103. The sample results are presented in Tables B2-2 through B2-12.

Although a historical potassium concentration could not be determined for tank 241-AP-103, it is certain that potassium is present in the tank. The majority of the tank waste was received from tank 241-AY-102, which was known to contain potassium (Van Fleet 1993). Potassium was not evaluated by the laboratory, but its estimated concentration in tank 241-AP-103 was calculated from the mass and charge balance (Section B3.3.2). 


\section{B2.2.2 Gaseous Hydride Atomic Absorption Spectroscopy}

Arsenic and selenium were analyzed according to procedures LA-355-131 and LA-362-131, respectively. The results are presented in Tables B2-13 and B2-14. $\rightarrow \infty$

\section{B2.2.3 Cold Vapor Atomic Absorption Spectroscopy}

Mercury was analyzed according to procedure LA-325-102. The results are presented in Table B2-15.

\section{B2.2.4 Toxicity Characteristic Leaching Procedure}

Arsenic, cadmium, and chromium were detected in the waste but exhibited average concentrations below their respective Toxicity Characteristic Leaching Procedure threshold values (EPA 1990). The following analytes were not detected in any of the tank 241-AP-103 samples: barium, lead, mercury, selenium, and silver.

\section{B2.2.5 Ion Chromatography}

The following anions were determined by using procedure LA-533-105: chloride, fluoride, nitrate, nitrite, phosphate, and sulfate. All of the analytes were detected in the waste samples. The results are presented in Tables B2-16 through B2-21.

\section{B2.2.6 Kjeldahl Method}

The ammonia analysis was performed by procedure LA-634-102. The sample results are presented in Table B2-22.

\section{B2.2.7 Titration}

Hydroxide was determined by using procedure LA-661-102. The sample results are presented in Table B2-23.

\section{B2.2.8 Distillation/Spectrometric Analysis}

Cyanide was determined by using procedure LA-695-101. The sample results are presented in Table B2-24. 


\section{B2.3 ORGANIC ANALYSES}

Although not required by the current safety screening or waste compatibility DQOs, TOC and total inorganic carbon (TIC) were required analytes of the 1991 samples.

In addition to TOC and TIC, samples were analyzed for volatile and semivolatile organic constituents. The samples were analyzed using uncontrolled draft procedures that largely complied with analytical protocols given in the EPA Contract Laboratory Statement of Work (EPA 1991). Because of their volatile nature and relatively small contribution to the waste as indicated by historical records, the appearance of these compounds in tank 241-AP-103 is not expected.

\section{B2.3.1 Total Inorganic Carbon}

Total inorganic carbon was determined by using procedure LA-622-102. The sample results are presented in Table B2-25.

\section{B2.3.2 Total Organic Carbon}

Total organic carbon was determined using procedure LA-344-105. The sample results are presented in Table B2-26.

\section{B2.3.3 Volatile Organic Compounds}

Volatile organic compounds are listed in Tables B2-27 and B2-28. None of the volatile organic target compounds were considered to be detected in the samples except acetone. The presence of acetone may have been caused by laboratory contamination, but the observed concentrations were too high to dismiss in the absence of further evidence. The few tentatively identified volatile organic compounds that appeared during the analyses were of no concern because none of them demonstrated a concentration above $25 \mathrm{ppb}$.

The data associated with acetone are presented even though the results are questionable. Because the samples were analyzed well beyond the maximum allowable holding times for volatile organic analyses, it is likely that the acetone results are extremely low. If the actual concentration of acetone is significantly higher, the emissions from the evaporator process could become an issue under the Resource Conservation and Recovery Act.

\section{B2.3.4 Semivolatile Organic Compounds}

Semivolatile organic compounds were not detected in tank 241-AP-103. With regard to the tentatively identified semivolatile organics, a reaction between the waste matrix and the 
organic surrogate compounds led to the detection of nitration reaction products. These compounds, however, were not indigenous to the tank. The presence of 2,4-dichloropentane was not anticipated upon review of the available historical data, but the compoind was found in appreciable concentrations in five samples (R937, R941, R942, R943, and R944). Because the detection of 2,4-dichloropentane could not be dismissed on the basis of contamination, the data were included in Table B2-30.

\section{B2.4 RADIOCHEMICAL ANALYSES}

\section{B2.4.1 Gamma Energy Analysis}

The activities of the following radionuclides were determined by gamma energy analysis according to procedure LA-548-121: ${ }^{144} \mathrm{Ce} / \mathrm{Pr},{ }^{134} \mathrm{Cs},{ }^{137} \mathrm{Cs},{ }^{60} \mathrm{Co},{ }^{154 / 155} \mathrm{Eu},{ }^{94 / 95} \mathrm{Nb},{ }^{226} \mathrm{Ra}$, ${ }^{106} \mathrm{Ru} / \mathrm{Rh}$, and ${ }^{113} \mathrm{Sn}$. The activity of ${ }^{129} \mathrm{I}$ was determined by low energy gamma analysis according to procedure LA-378-103. The results from the gamma analyses are presented in Tables B2-31 through B2-43.

\section{B2.4.2 Alpha Energy Analysis}

The following radionuclides were evaluated by alpha energy analysis according to procedure LA-503-156: ${ }^{234} \mathrm{U},{ }^{235} \mathrm{U},{ }^{238} \mathrm{U},{ }^{239 / 240} \mathrm{Pu}$, and ${ }^{241} \mathrm{Am}$. The results are presented in Table B2-44 and $\mathrm{B} 2-48$.

\section{B2.4.3 Liquid Scintillation}

Tritium, ${ }^{14} \mathrm{C},{ }^{79} \mathrm{Se}$, and ${ }^{99} \mathrm{Tc}$ were analyzed by liquid scintillation according to procedures LA-218-114, LA-348-104, LA-365-131, and LA-438-101, respectively. The sample results are presented in Tables B2-49 through B2-52.

\section{B2.4.4 Alpha Proportional Counting}

Total uranium was analyzed by alpha proportional counting and reported in $\mu \mathrm{g} / \mathrm{L}$ rather than $\mu \mathrm{Ci} / \mathrm{L}$ according to procedure LA-508-101. The results are presented in Table B2-53.

\section{B2.4.5 Beta Proportional Counting}

The activity of ${ }^{90} \mathrm{Sr}$ was evaluated by beta proportional counting according to procedure LA-220-101. The results are presented in Table B2-54. 


\section{B2.5 PHYSICAL ANALYSES}

\section{B2.5.1 Specific Gravity}

As required by the safety screening DQO, the specific gravity ( $\mathrm{SpG}$ ) of the liquids was determined according to procedure LA-510-112. No other physical tests were required or performed. The results are presented in Table B2-55.

\section{B2.6 THERMODYNAMIC ANALYSES}

\section{B2.6.1 Differential Scanning Calorimetry}

In a differential scanning calorimetry (DSC) analysis, heat absorbed or emitted by a substance is measured while the temperature of the sample is heated at a constant rate. Nitrogen is passed over the sample material to remove any gases being released. The onset temperature for an endothermic or exothermic event is determined graphically.

No exothermic reactions were apparent from the DSC analyses for tank 241-AP-103. No exothermic reactions were noted, and therefore the upper limit of a 95 percent confidence interval was not calculated. 
Table B2-2. Tank 241-AP-103 Analytical Results: Aluminum.

\begin{tabular}{|c|c|c|c|c|c|}
\hline sinpe & 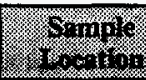 & xyon & 3.72 .211 & 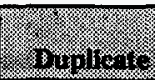 & 41 \\
\hline \multicolumn{2}{|c|}{ 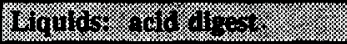 } & - & 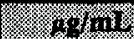 & $4 \% 11 \%$ & $\% / 111$ \\
\hline R933-8750 & \multirow[t]{4}{*}{ Riser 1} & Whole & 101 & 103 & 102 \\
\hline R934 & & Whole & 76 & -- & 76 \\
\hline R935 & & Whole & 307 & -- & 307 \\
\hline R945 & & Whole & 550 & $-\cdots$ & 550 \\
\hline R936 & \multirow[t]{4}{*}{ Riser 27} & Whole & 103 & -- & 103 \\
\hline R937 & & Whole & 230 & $-\cdots$ & 230 \\
\hline R941-8750 & & Whole & 260 & 258 & 259 \\
\hline R942 & & Whole & 560 & -- & 560 \\
\hline R943 & \multirow[t]{2}{*}{ Riser 28} & Whole & 104 & $\ldots$ & 104 \\
\hline R944 & & Whole & 171 & $\ldots$ & 171 \\
\hline
\end{tabular}

Table B2-3. Tank 241-AP-103 Analytical Results: Barium.

\begin{tabular}{|c|c|c|c|c|c|}
\hline$\frac{6}{6 \sin 01}$ & (.ing) & 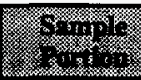 & 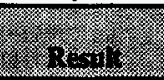 & 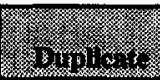 & 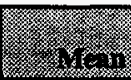 \\
\hline \multicolumn{3}{|c|}{ 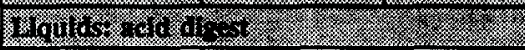 } & (1) & 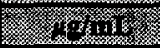 & 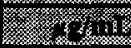 \\
\hline R933-8750 & \multirow[t]{4}{*}{ Riser 1} & Whole & $<0.065$ & $<0.065$ & $<0.065$ \\
\hline R934 & & Whole & $<0.065$ & - & $<0.065$ \\
\hline R935 & & Whole & $<0.065$ & $\cdots$ & $<0.065$ \\
\hline R945 & & Whole & $<0.065$ & - & $<0.065$ \\
\hline R936 & \multirow[t]{4}{*}{ Riser 27} & Whole & $<0.065$ & - & $<0.065$ \\
\hline R937 & & Whole & $<0.065$ & $-\cdots$ & $<0.065$ \\
\hline R941-8750 & & Whole & $<0.065$ & $<0.065$ & $<0.065$ \\
\hline R942 & & Whole & $<0.065$ & - & $<0.065$ \\
\hline R943 & \multirow[t]{2}{*}{ Riser 28} & Whole & $<0.065$ & -- & $<0.065$ \\
\hline R944 & & Whole & $<0.065$ & -- & $<0.065$ \\
\hline
\end{tabular}


HNF-SD-WM-ER-359, Rev. 1

Table B2-4. Tank 241-AP-103 Analytical Results: Cadmium.

\begin{tabular}{|c|c|c|c|c|c|}
\hline Sintion & (3.ing & 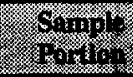 & 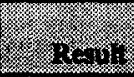 & 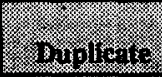 & (2) \\
\hline \multicolumn{3}{|c|}{ 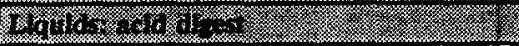 } & 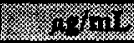 & (1) & V \\
\hline R933-8750 & \multirow[t]{4}{*}{ Riser 1} & Whole & 0.0685 & 0.0745 & 0.0715 \\
\hline R934 & & Whole & 0.048 & -- & 0.048 \\
\hline R935 & & Whole & 0.133 & -- & 0.133 \\
\hline R945 & & Whole & 0.18 & - & 0.18 \\
\hline R936 & \multirow[t]{4}{*}{ Riser 27} & Whole & 0.0645 & $-\cdots$ & 0.0645 \\
\hline R937 & & Whole & 0.124 & -- & 0.124 \\
\hline R941-8750 & & Whole & 0.126 & 0.125 & 0.1255 \\
\hline R942 & & Whole & $0: 183$ & -- & 0.183 \\
\hline R943 & \multirow[t]{2}{*}{ Riser 28} & Whole & 0.081 & -- & 0.081 \\
\hline R944 & & Whole & 0.097 & -- & 0.097 \\
\hline
\end{tabular}

Table B2-5. Tank 241-AP-103 Analytical Results: Chromium.

\begin{tabular}{|c|c|c|c|c|c|}
\hline 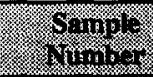 & 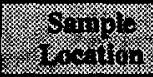 & 等 & (2) & 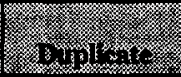 & (3) \\
\hline 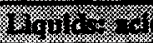 & 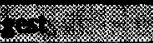 & 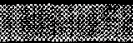 & 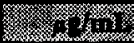 & 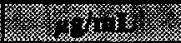 & 经 \\
\hline R933-8750 & \multirow[t]{4}{*}{ Riser 1} & Whole & 3.51 & 3.56 & 3.535 \\
\hline R934 & & Whole & 2.05 & -- & 2.05 \\
\hline R935 & & Whole & 4.87 & -- & 4.87 \\
\hline R945 & & Whole & 6.4 & -- & 6.4 \\
\hline R936 & \multirow[t]{4}{*}{ Riser 27} & Whole & 3.38 & -- & 3.38 \\
\hline R937 & & Whole & 4.48 & -- & 4.48 \\
\hline R941-8750 & & Whole & 5.05 & 4.67 & 4.86 \\
\hline R942 & & Whole & 6.6 & -- & 6.6 \\
\hline R943 & \multirow[t]{2}{*}{ Riser 28} & Whole & 3.53 & -- & 3.53 \\
\hline R944 & & Whole & 4.15 & $\ldots$ & 4.15 \\
\hline
\end{tabular}


Table B2-6. Tank 241-AP-103 Analytical Results: Iron.

\begin{tabular}{|c|c|c|c|c|c|}
\hline $\begin{array}{l}\text { Samole- } \\
\text { tominive }\end{array}$ & S.m.n. & 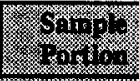 & f & 3inicis & 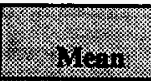 \\
\hline \multicolumn{3}{|c|}{ 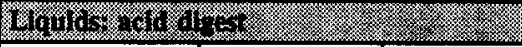 } & I. & 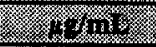 & 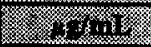 \\
\hline R933-8750 & \multirow[t]{4}{*}{ Riser 1} & Whole & $<0.435$ & $<0.435$ & $<0.435$ \\
\hline R934 & & Whole & 0.481 & --- & $0.481^{\propto C_{i b}}$ \\
\hline R935 & & Whole & 0.99 & $\begin{array}{ll}-- \\
-\cdots\end{array}$ & $0.99^{\mathrm{aC:b}}$ \\
\hline R945 & & Whole & $<0.435$ & $\cdots$ & $<0.435$ \\
\hline R936 & \multirow[t]{4}{*}{ Riser 27} & Whole & $<0.435$ & -- & $<0.435$ \\
\hline R937 & & Whole & $<0.435$ & -- & $<0.435$ \\
\hline R941-8750 & & Whole & 1.52 & 1.19 & $1.355^{\mathrm{QC:e}}$ \\
\hline R942 & & Whole & 2.67 & -- & 2.67 \\
\hline R943 & \multirow[t]{2}{*}{ Riser 28} & Whole & 0.63 & -- & 0.63 \\
\hline R944 & & Whole & $<0.435$ & $\cdots$ & $<0.435$ \\
\hline
\end{tabular}

Table B2-7. Tank 241-AP-103 Analytical Results: Lead.

\begin{tabular}{|c|c|c|c|c|c|}
\hline 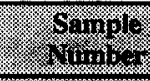 & S.mplo & ( & f & ( & (2) \\
\hline 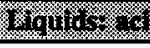 & $\frac{18}{4}$ & (3.) & 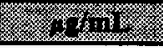 & 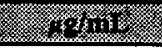 & $2=1$ \\
\hline R933-8750 & \multirow[t]{4}{*}{ Riser 1} & Whole & $<0.4$ & $<0.4$ & $<0.4$ \\
\hline R934 & & Whole & $<0.4$ & - & $<0.4$ \\
\hline R935 & & Whole & $<0.4$ & -- & $<0.4$ \\
\hline R945 & & Whole & $<0.4$ & - & $<0.4$ \\
\hline R936 & \multirow[t]{4}{*}{ Riser 27} & Whole & $<0.4$ & -- & $<0.4$ \\
\hline R937 & & Whole & $<0.4$ & - & $<0.4$ \\
\hline R941-8750 & & Whole & $<0.4$ & $<0.4$ & $<0.4$ \\
\hline R942 & & Whole & $<0.4$ & -- & $<0.4$ \\
\hline R943 & \multirow[t]{2}{*}{ Riser 28} & Whole & $<0.4$ & -- & $<0.4$ \\
\hline R944 & & Whole & $<0.4$ & -- & $<0.4$ \\
\hline
\end{tabular}


Table B2-8. Tank 241-AP-103 Analytical Results: Magnesium.

\begin{tabular}{|c|c|c|c|c|c|}
\hline 的 & (6) & 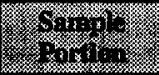 & (3) & 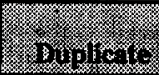 & (6) \\
\hline \multicolumn{3}{|c|}{ ming } & (18. & 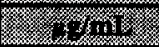 & (3) \\
\hline R933-8750 & \multirow[t]{4}{*}{ Riser 1} & Whole & 1.04 & 1.13 & 1.085 \\
\hline R934 & & Whole & 1.03 & - & 1.03 \\
\hline R935 & & Whole & 1.53 & - & 1.53 \\
\hline R945 & & Whole & $<0.255$ & - & $<0.255$ \\
\hline R936 & \multirow[t]{4}{*}{ Riser 27} & Whole & 1.15 & - & 1.15 \\
\hline R937 & & Whole & 1.14 & - & 1.14 \\
\hline R941-8750 & & Whole & $<0.255$ & $<0.255$ & $<0.255$ \\
\hline R942 & & Whole & $<0.255$ & -- & $<0.255$ \\
\hline R943 & \multirow[t]{2}{*}{ Riser 28} & Whole & $<0.255$ & -- & $<0.255$ \\
\hline R944 & & Whole & $<0.255$ & -- & $<0.255$ \\
\hline
\end{tabular}

Table B2-9. Tank 241-AP-103 Analytical Results: Manganese.

\begin{tabular}{|c|c|c|c|c|c|}
\hline 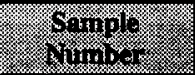 & 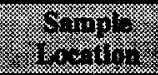 & 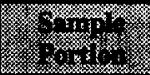 & 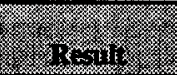 & 1314111,2 & 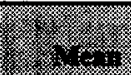 \\
\hline 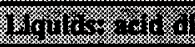 & $1+4 x_{1}$ & 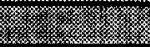 & (1) & (x) & (3. \\
\hline R933-8750 & \multirow[t]{4}{*}{ Riser 1} & Whole & $<0.015$ & $<0.015$ & $<0.015$ \\
\hline R934 & & Whole & $<0.015$ & -- & $<0.015$ \\
\hline R935 & & Whole & 0.0515 & - & 0.0515 \\
\hline R945 & & Whole & 0.023 & - & 0.023 \\
\hline R936 & \multirow[t]{4}{*}{ Riser 27} & Whole & $<0.015$ & 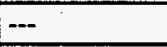 & $<0.015$ \\
\hline R937 & & Whole & 0.045 & - & 0.045 \\
\hline R941-8750 & & Whole & 0.0216 & 0.102 & $0.0618^{\mathrm{QC}: e}$ \\
\hline R942 & & Whole & 0.0341 & -- & 0.0341 \\
\hline R943 & \multirow[t]{2}{*}{ Riser 28} & Whole & $<0.015$ & -+ & $<0.015$ \\
\hline R944 & & Whole & $<0.015$ & -- & $<0.015$ \\
\hline
\end{tabular}


Table B2-10. Tank 241-AP-103 Analytical Results: Silver.

\begin{tabular}{|c|c|c|c|c|c|}
\hline 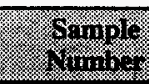 & 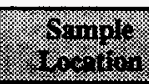 & 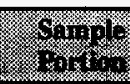 & 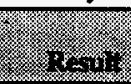 & 34013 & 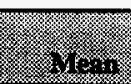 \\
\hline \multicolumn{3}{|c|}{ 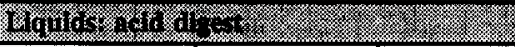 } & 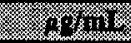 & (6) & $8+2+1$ \\
\hline R933-8750 & \multirow[t]{4}{*}{ Riser 1} & Whole & $<0.04$ & $<0.04$ & $<0.04$ \\
\hline R934 & & Whole & $<0.04$ & --- & $<0.04$ \\
\hline R935 & & Whole & $<0.04$ & $\cdots$ & $<0.04$ \\
\hline R945 & & Whole & $<0.04$ & -- & $<0.04$ \\
\hline R936 & \multirow[t]{4}{*}{ Riser 27} & Whole & $<0.04$ & $\cdots$ & $<0.04$ \\
\hline R937 & & Whole & $<0.04$ & $\cdots$ & $<0.04$ \\
\hline R941-8750 & & Whole & $<0.04$ & $<0.04$ & $<0.04$ \\
\hline R942 & & Whole & $<0.04$ & -- & $<0.04$ \\
\hline R943 & \multirow[t]{2}{*}{ Riser 28} & Whole & $<0.04$ & -- & $<0.04$ \\
\hline R944 & & Whole & $<0.04$ & $\cdots$ & $<0.04$ \\
\hline
\end{tabular}

Table B2-11. Tank 241-AP-103 Analytical Results: Sodium.

\begin{tabular}{|c|c|c|c|c|c|}
\hline 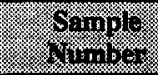 & f & (1) & 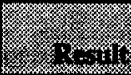 & 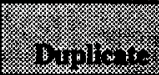 & $f(x, 1,0 ; 1$ \\
\hline 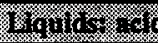 & 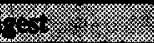 & 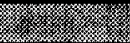 & (3) & 14 & 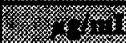 \\
\hline R933-8750 & \multirow[t]{4}{*}{ Riser 1} & Whole & 3,640 & 3,690 & $3,665^{\mathrm{OC}: f}$ \\
\hline R934 & & Whole & 2,320 & - & $2,320^{\mathrm{QC}: \mathrm{f}}$ \\
\hline R935 & & Whole & 2,460 & -- & $2,460^{e c: f, b}$ \\
\hline R945 & & Whole & 12,000 & $\cdots$ & $12,000^{e c: f}$ \\
\hline R936 & \multirow[t]{4}{*}{ Riser 27} & Whole & 3,820 & -- & $3,820^{\mathrm{QC}: f}$ \\
\hline R937 & & Whole & 2,050 & -- & $2,050^{\circ \mathrm{C}: t}$ \\
\hline R941-8750 & & Whole & 6,510 & 6,570 & $6,540^{\mathrm{QC}: ?, \mathrm{~b}}$ \\
\hline R942 & & Whole & 11,700 & $-\cdots$ & $11,700^{\mathrm{ec}: \mathrm{f}}$ \\
\hline R943 & \multirow[t]{2}{*}{ Riser 28} & Whole & 3,700 & -- & $3,700^{\text {ec:f }}$ \\
\hline R944 & & Whole & 4,870 & -- & $4,870^{Q C: f}$ \\
\hline
\end{tabular}


Table B2-12. Tank 241-AP-103 Analytical Results: Zinc.

\begin{tabular}{|c|c|c|c|c|c|}
\hline 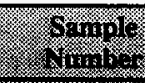 & 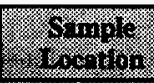 & 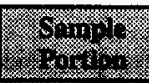 & (2) & 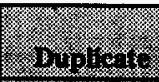 & 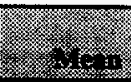 \\
\hline \multicolumn{3}{|c|}{ Y } & 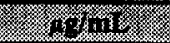 & (2) & 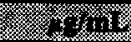 \\
\hline R933-8750 & \multirow[t]{4}{*}{ Riser 1} & Whole & 0.0466 & 0.0204 & $0.0335^{\mathrm{QC:e}}$ \\
\hline R934 & & Whole & $<0.02$ &.- & $<0.02$ \\
\hline R935 & & Whole & 1.21 & -- & 1.21 \\
\hline R945 & & Whole & 0.309 & $\cdots$ & 0.309 \\
\hline R936 & \multirow[t]{4}{*}{ Riser 27} & Whole & 0.55 & -- & 0.55 \\
\hline R937 & & Whole & 0.221 & -- & 0.221 \\
\hline R941-8750 & & Whole & 0.041 & 0.055 & $0.048^{\mathrm{QC:e}}$ \\
\hline R942 & & Whole & 0.309 & $\cdots$ & 0.309 \\
\hline R943 & \multirow[t]{2}{*}{ Riser 28} & Whole & $<0.02$ & -- & $<0.02$ \\
\hline R944 & & Whole & $<0.02$ & --- & $<0.02$ \\
\hline
\end{tabular}

Table B2-13. Tank 241-AP-103 Analytical Results: Arsenic.

\begin{tabular}{|c|c|c|c|c|c|}
\hline 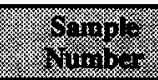 & 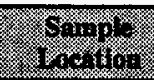 & 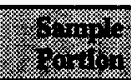 & 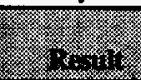 & 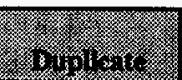 & 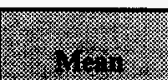 \\
\hline 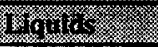 & 标 & sk & 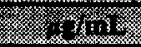 & 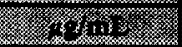 & (k) \\
\hline R933-5795 & \multirow[t]{4}{*}{ Riser 1} & Whole & 0.048 & 0.056 & $0.052^{\mathrm{QC}: \mathrm{c}}$ \\
\hline R934-5795 & & Whole & 0.035 & -- & 0.035 \\
\hline R935 & & Whole & 0.055 & - & 0.055 \\
\hline R945 & & Whole & 0.061 & -- & 0.061 \\
\hline $\mathbf{R 9 3 6}$ & \multirow[t]{4}{*}{ Riser 27} & Whole & 0.0445 & -- & 0.0445 \\
\hline $\mathbf{R 9 3 7}$ & & Whole & 0.049 & $\cdots$ & 0.049 \\
\hline R941-5795 & & Whole & 0.042 & 0.036 & 0.039 \\
\hline R942 & & Whole & 0.084 & - & 0.084 \\
\hline R943 & \multirow[t]{2}{*}{ Riser 28} & Whole & 0.028 & 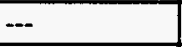 & 0.028 \\
\hline R944-5728 & & Whole & 0.035 & -- & 0.035 \\
\hline
\end{tabular}


Table B2-14. Tank 241-AP-103 Analytical Results: Selenium.

\begin{tabular}{|c|c|c|c|c|c|}
\hline (2) & 作 & 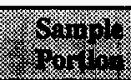 & $x^{2}=\sqrt[1]{1}$ & $\frac{1}{4}$ & 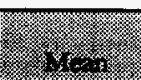 \\
\hline oing & & 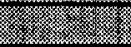 & (3) & . & (1) \\
\hline R933-5796 & \multirow[t]{4}{*}{ Riser 1} & Whole & $<0.02$ & $<0.02$ & $<0.02$ \\
\hline R934-5796 & & Whole & $<0.005$ & -- & $<0.005$ \\
\hline R935 & & Whole & $<0.005$ & -- & $<0.005$ \\
\hline R945 & & Whole & 0.0059 & -- & 0.0059 \\
\hline R936 & \multirow[t]{4}{*}{ Riser 27} & Whole & $<0.005$ & -- & $<0.005$ \\
\hline R937 & & Whole & $<0.005$ & -- & $<0.005$ \\
\hline R941-5796 & & Whole & $<0.02$ & $<0.02$ & $<0.02$ \\
\hline R942 & & Whole & $<0.0071$ & -+ & $<0.0071$ \\
\hline R943 & \multirow[t]{2}{*}{ Riser 28} & Whole & $<0.005$ & - & $<0.005$ \\
\hline R944-5728 & & Whole & $<0.005$ & -- & $<0.005$ \\
\hline
\end{tabular}

Table B2-15. Tank 241-AP-103 Analytical Results: Mercury.

\begin{tabular}{|c|c|c|c|c|c|}
\hline 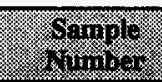 & 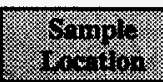 & 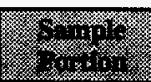 & 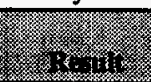 & Bungis = & 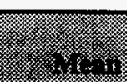 \\
\hline Miring & স্যে & 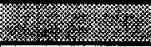 & (1) & r. & 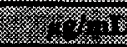 \\
\hline R933-5797 & \multirow[t]{4}{*}{ Riser 1} & Whole & $<0.0017$ & $<0.0017$ & $<0.0017$ \\
\hline R934-5797 & & Whole & $<0.0017$ & -- & $<0.0017$ \\
\hline R935 & & Whole & $<0.0017$ & - & $<0.0017$ \\
\hline R945 & & Whole & $<0.0017$ & -- & $<0.0017$ \\
\hline R936 & \multirow[t]{4}{*}{ Riser 27} & Whole & $<0.0017$ & - & $<0.0017$ \\
\hline R937 & & Whole & $<0.0017$ & -- & $<0.0017$ \\
\hline R941-5797 & & Whole & $<0.0017$ & $<0.0017$ & $<0.0017$ \\
\hline R942 & & Whole & $<0.0017$ & - & $<0.0017$ \\
\hline R943 & \multirow[t]{2}{*}{ Riser 28} & \begin{tabular}{|l} 
Whole \\
\end{tabular} & $<0.005$ & -- & $<0.005$ \\
\hline R944-5728 & & Whole & $<0.0017$ & -- & $<0.0017$ \\
\hline
\end{tabular}


Table B2-16. Tank 241-AP-103 Analytical Results: Chloride.

\begin{tabular}{|c|c|c|c|c|c|}
\hline 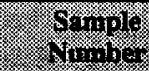 & 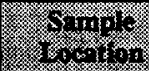 & (6) & $(2,-3)$ & $40,1014=$ & 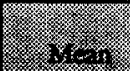 \\
\hline King & r & 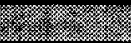 & 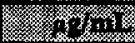 & (2) & 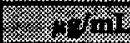 \\
\hline R933-5772 & \multirow[t]{4}{*}{ Riser 1} & Whole & 35.5 & 37.6 & 36.55 \\
\hline R934-5772 & & Whole & 34.5 & -- & 34.5 \\
\hline R935 & & Whole & 49.8 & $-\cdots$ & 49.8 \\
\hline R945 & & Whole & 103 & -- & 103 \\
\hline R936 & \multirow[t]{4}{*}{ Riser 27} & Whole & 31 & -- & 31 \\
\hline R937 & & Whole & 17.8 & $\cdots$ & 17.8 \\
\hline R941-5772 & & Whole & 51.2 & 51 & 51.1 \\
\hline R942 & & Whole & 92.9 & -- & 92.9 \\
\hline R943 & \multirow[t]{2}{*}{ Riser 28} & Whole & 38.3 & -- & 38.3 \\
\hline R944-5728 & & Whole & 39.8 & -- & 39.8 \\
\hline
\end{tabular}

Table B2-17. Tank 241-AP-103 Analytical Results: Fluoride.

\begin{tabular}{|c|c|c|c|c|c|}
\hline 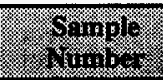 & 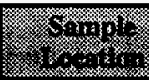 & 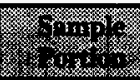 & (6) & 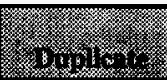 & (3) \\
\hline 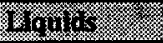 & 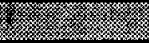 & 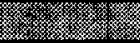 & (2) & 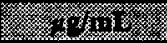 & 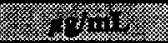 \\
\hline R933-5772 & \multirow[t]{4}{*}{ Riser 1} & Whole & 60.4 & 61.9 & 61.15 \\
\hline R934-5772 & & Whole & 88.2 & $\ldots$ & 88.2 \\
\hline R935 & & Whole & 178 & $\cdots$ & 178 \\
\hline R945 & & Whole & 260 & $-\cdots$ & 260 \\
\hline R936 & \multirow[t]{4}{*}{ Riser 27} & Whole & 60.3 & $\ldots$ & 60.3 \\
\hline R937 & & Whole & 54.1 & -- & 54.1 \\
\hline R941-5772 & & Whole & 130 & 129 & 129.5 \\
\hline R942 & & Whole & 305 & $-\cdots$ & 305 \\
\hline R943 & \multirow[t]{2}{*}{ Riser 28} & Whole & 60.6 & -- & 60.6 \\
\hline R944-5728 & & Whole & 96.4 & $\cdots$ & 96.4 \\
\hline
\end{tabular}


Table B2-18. Tank 241-AP-103 Analytical Results: Nitrate.

\begin{tabular}{|c|c|c|c|c|c|}
\hline $\begin{array}{l}\text { Sample } \\
\text { Yront }\end{array}$ & S Sample & Sanplo & 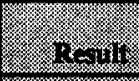 & minglicon. & (2) \\
\hline Miguldos & 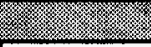 & 8 & 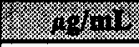 & 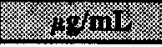 & 28. \\
\hline R933-5772 & \multirow[t]{4}{*}{ Riser 1} & Whole & 1,690 & 1,670 & 1,680 \\
\hline R934-5772 & & Whole & 2,060 & - & 2,060 \\
\hline R935 & & Whole & 3,500 & - & 3,500 \\
\hline R945 & & Whole & 9,790 & |-- & 9,790 \\
\hline R936 & \multirow[t]{4}{*}{ Riser 27} & Whole & 1,720 & -- & 1,720 \\
\hline R937 & & Whole & 3,250 & - & 3,250 \\
\hline R941-5772 & & Whole & 4,460 & 4,500 & 4,480 \\
\hline R942 & & Whole & 9,440 & -- & 9,440 \\
\hline R943 & \multirow[t]{2}{*}{ Riser 28} & Whole & 1,620 & - & 1,620 \\
\hline R944-5728 & & Whole & 2,850 & --- & 2,850 \\
\hline
\end{tabular}

Table B2-19. Tank 241-AP-103 Analytical Results: Nitrite.

\begin{tabular}{|c|c|c|c|c|c|}
\hline $\begin{array}{l}\text { Sarnole } \\
\text { Mino }\end{array}$ & Sornolo & 80 & 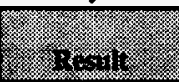 & 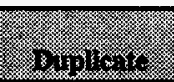 & 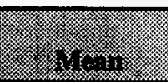 \\
\hline 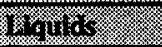 & (28- & (-) & 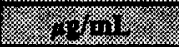 & 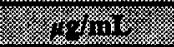 & (7) \\
\hline R933-5772 & \multirow[t]{4}{*}{ Riser 1} & Whole & 1,130 & 1,140 & $1,135^{\mathrm{CO}: \mathrm{d}}$ \\
\hline R934-5772 & & \begin{tabular}{|l|} 
Whole \\
\end{tabular} & 983 & -- & 983 \\
\hline R935 & & Whole & 1,380 & -- & 1,380 \\
\hline R945 & & Whole & 1,810 & - & 1,810 \\
\hline R936 & \multirow[t]{4}{*}{ Riser 27} & Whole & 1,130 & -- & 1,130 \\
\hline R937 & & Whole & 1,280 & -- & 1,280 \\
\hline R941-5772 & & Whole & 1,260 & 1,250 & 1,255 \\
\hline R942 & & Whole & 1,700 & --- & 1,700 \\
\hline R943 & \multirow[t]{2}{*}{ Riser 28} & Whole & 1,120 & -- & 1,120 \\
\hline R944-5728 & & Whole & 1,200 & $-\cdots$ & 1,200 \\
\hline
\end{tabular}


Table B2-20. Tank 241-AP-103 Analytical Results: Phosphate.

\begin{tabular}{|c|c|c|c|c|c|}
\hline 9.mplo & 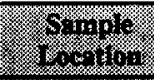 & Sing & (3) & 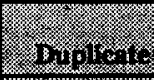 & (1) \\
\hline hing & 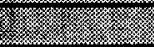 & (2) & thing: & (1) & (8. \\
\hline R933-5772 & \multirow[t]{4}{*}{ Riser 1} & Whole & 134 & 120 & 127 \\
\hline R934-5772 & & Whole & 147 & $-\cdots$ & 147 \\
\hline R935 & & Whole & 151 & - & 151 \\
\hline R945 & & Whole & 166 & -- & 166 \\
\hline R936 & \multirow[t]{4}{*}{ Riser 27} & Whole & 121 & -- & 121 \\
\hline R937 & & Whole & 139 & -- & 139 \\
\hline R941-5772 & & Whole & 134 & 140 & 137 \\
\hline R942 & & Whole & 149 & --- & 149 \\
\hline R943 & \multirow[t]{2}{*}{ Riser 28} & Whole & 112 & $-\cdots$ & 112 \\
\hline R944-5728 & & Whole & 134 & -- & 134 \\
\hline
\end{tabular}

Table B2-21. Tank 241-AP-103 Analytical Results: Sulfate.

\begin{tabular}{|c|c|c|c|c|c|}
\hline (6) & 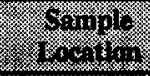 & (3) & 3 & (4) & 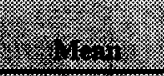 \\
\hline (rigly & 妶 & 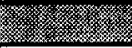 & 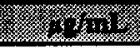 & 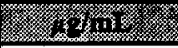 & 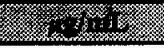 \\
\hline R933-5772 & \multirow[t]{4}{*}{ Riser 1} & Whole & 420 & 483 & 451.5 \\
\hline R934-5772 & & Whole & 502 & -- & 502 \\
\hline R935 & & Whole & 318 & $-\cdots$ & 318 \\
\hline R945 & & Whole & 163 & -- & 163 \\
\hline R936 & \multirow[t]{4}{*}{ Riser 27} & Whole & 414 & $\ldots$ & 414 \\
\hline R937 & & Whole & 196 & +- & 196 \\
\hline R941-5772 & & Whole & 395 & 396 & 395.5 \\
\hline R942 & & Whole & 162 & - & 162 \\
\hline R943 & \multirow[t]{2}{*}{ Riser 28} & Whole & 418 & -- & 418 \\
\hline R944-5728 & & Whole & 482 & - & 482 \\
\hline
\end{tabular}


Table B2-22. Tank 241-AP-103 Analytical Results: Ammonia.

\begin{tabular}{|c|c|c|c|c|c|}
\hline (6) & 6. & (1) & (3) & Muticis & (.) \\
\hline 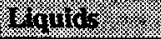 & (4) & (3) & 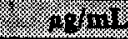 & $48 \mathrm{~m}$ & 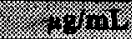 \\
\hline R933-5728 & \multirow[t]{4}{*}{ Riser 1} & Whole & $<45$ & -- & $<45$ \\
\hline R934-5728 & & Whole & $<22.5$ & - & $<22.5$ \\
\hline R935 & & Whole & $<35$ & -- & $<35$ \\
\hline R945 & & Whole & $<65.7$ & - & $<65.7$ \\
\hline R936 & \multirow[t]{4}{*}{ Riser 27} & Whole & $<22.5$ & $\because$ & $<22.5$ \\
\hline R937 & & Whole & $<22.5$ & -- & $<22.5$ \\
\hline R941-5728 & & Whole & $<90$ & $<90$ & $<90$ \\
\hline R942 & & Whole & $<90$ & - & $<90$ \\
\hline R943 & \multirow[t]{2}{*}{ Riser 28} & Whole & $<90$ & - & $<90$ \\
\hline R944-5728 & & Whole & $<13.1$ & $<13.1$ & $<13.1$ \\
\hline
\end{tabular}

Table B2-23. Tank 241-AP-103 Analytical Results: Hydroxide.

\begin{tabular}{|c|c|c|c|c|c|}
\hline 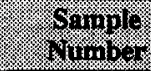 & oping & $\frac{x+1,10}{210}$ & ; $;+111$ & $8 \ln _{10}$ & $4=13$ \\
\hline monos & 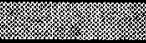 & 8 & 40111 & -7111 & 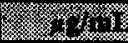 \\
\hline R933-5729 & \multirow[t]{4}{*}{ Riser 1} & Whole & 549 & 542 & 545.5 \\
\hline R934-5729 & & Whole & 850 & -- & 850 \\
\hline R935 & & Whole & 1,890 & -- & 0.189 \\
\hline R945 & & Whole & 3,350 & -- & 3,350 \\
\hline R936 & \multirow[t]{4}{*}{ Riser 27} & Whole & 1,120 & $\ldots$ & 1,120 \\
\hline R937 & & Whole & 1,500 & -- & 1,500 \\
\hline R941-5729 & & Whole & 1,610 & 1,400 & 1,505 \\
\hline R942 & & Whole & 3,430 & -- & 3,430 \\
\hline R944-5728 & Riser 28 & Whole & 991 & -- & 991 \\
\hline
\end{tabular}


HNF-SD-WM-ER-359, Rev. 1

Table B2-24. Tank 241-AP-103 Analytical Results: Cyanide.

\begin{tabular}{|c|c|c|c|c|c|}
\hline $\begin{array}{l}\text { Samplo } \\
\text { Silmort }\end{array}$ & Somingile & 28 & 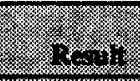 & (2) & 2 \\
\hline 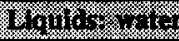 & 76.6 & (- - & (8) & $1.2 .5 \sin$ & 3.1 .1 .13 \\
\hline R933-5778 & \multirow[t]{4}{*}{ Riser 1} & Whole & $<1$ & $\ldots$ & $<1$ \\
\hline R934-5778 & & Whole & 0.495 & $-\ldots$ & 0.495 \\
\hline R935 & & Whole & 0.584 & $-\ldots$ & 0.584 \\
\hline R945 & & Whole & 0.61 & |-- & 0.61 \\
\hline R936 & \multirow[t]{4}{*}{ Riser 27} & Whole & 0.469 & --- & 0.469 \\
\hline R937 & & Whole & 0.527 & --- & 0.527 \\
\hline R941-5778 & & Whole & 0.6 & 0.61 & 0.605 \\
\hline R942 & & Whole & 0.61 & -- & 0.61 \\
\hline R943 & \multirow[t]{2}{*}{ Riser 28} & Whole & 0.511 & -- & 0.511 \\
\hline R944-5728 & & Whole & 0.552 & - & 0.552 \\
\hline
\end{tabular}

Table B2-25. Tank 241-AP-103 Analytical Results: Total Inorganic Carbon.

\begin{tabular}{|c|c|c|c|c|c|}
\hline Sample & Soringlo & (3) & (2) & 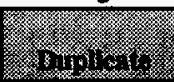 & (2) \\
\hline Whings & 1) & 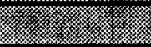 & (2) & ( 1.11 & ( \\
\hline R933-5726 & \multirow{4}{*}{ Riser 1} & Whole & 544 & - & 544 \\
\hline R934-5726 & & Whole & 498 & $\ldots$ & 498 \\
\hline R935 & & Whole & 522 & -- & 522 \\
\hline R945 & & Whole & 512 & - & 512 \\
\hline R936 & \multirow[t]{4}{*}{ Riser 27} & Whole & 430 & - & 430 \\
\hline R937 & & Whole & 460 & -- & 460 \\
\hline R941-5726 & & Whole & 443 & 455 & 449 \\
\hline R942 & & Whole & 650 & -- & 650 \\
\hline R943 & \multirow[t]{2}{*}{ Riser 28} & Whole & 530 & $\ldots$ & 530 \\
\hline R944 & & Whole & 545 & -- & 545 \\
\hline
\end{tabular}




\begin{tabular}{|c|c|c|c|}
\hline GN & 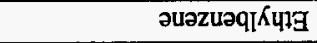 & IN & 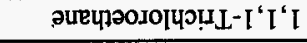 \\
\hline aN & วนəzuəq०10[Чว & $\mathbf{V} / \mathbf{N}$ & วuourang- \\
\hline $\mathbf{G N}$ & วuən|OL & aN & 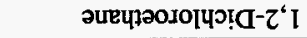 \\
\hline$\overline{\mathrm{aN}}$ & 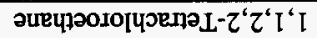 & aN & 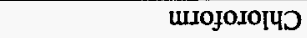 \\
\hline aN & 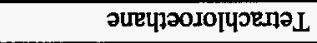 & aN & 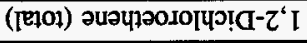 \\
\hline IN & әuоuехәH-ح & aN & วUЕчрәОIоІЧग!С-I I I \\
\hline aN & 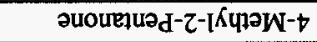 & $\overline{\mathrm{GN}}$ & 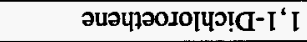 \\
\hline aN & wrojoworg & GN & әрџIns!̣ uоqreว \\
\hline $\mathbf{a N}$ & 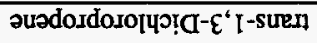 & aN & วu०1วอV \\
\hline $\mathbf{G N}$ & วuəztrag & aN & 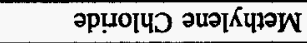 \\
\hline aN & 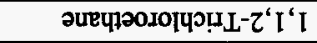 & ON & әแгчрอлоโЧว \\
\hline$\overline{\mathrm{GN}}$ & 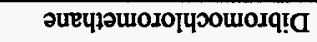 & $\overline{G N}$ & 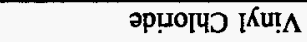 \\
\hline GN & 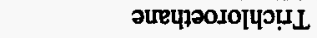 & aN & әน์บрәшошод \\
\hline GN & 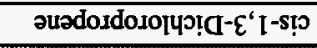 & $\mathbf{G N}$ & วน์црашогоЧว \\
\hline$y$ & 2. & (1) & 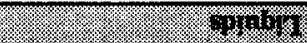 \\
\hline $11+2$ & $6 \%$ & $19+2 \%$ & $2 \% 10 \%$ \\
\hline
\end{tabular}

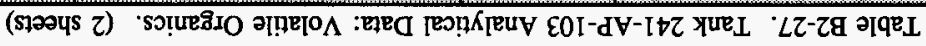

\begin{tabular}{|c|c|c|c|c|c|}
\hline$L 66$ & -- & $L^{*} 66$ & ગОЧМ & & $\downarrow t 6 \mathbf{d}$ \\
\hline$\angle L 8$ & -- & $\angle \cdot \angle 8$ & ગОЧМ & $8 Z$ Iәs!़ & $\varepsilon \nabla 6 \mathrm{~d}$ \\
\hline$s^{\circ} 16$ & $\cdots$ & $S^{\circ} 16$ & әюЧМ & \multirow[b]{4}{*}{ LZ Iอs!̣ } & $\tau \triangleright 68$ \\
\hline I'I6 & $S^{\prime} I 6$ & $\angle \circ 06$ & әООМ & & $\angle Z \angle S-I D 68$ \\
\hline OSI & --- & OSI & әоЧМ & & $\angle E 6 \mathrm{~d}$ \\
\hline OZI & -- & OZI & әГОЧМ & & $9 \varepsilon 6 \mathbf{d}$ \\
\hline 8.06 & $\cdots$ & 8.06 & ગОЧМ & \multirow[b]{4}{*}{ I IOS!̣ } & S†68 \\
\hline OEI & -- & $0 E I$ & गणОपМ & & SE68 \\
\hline OSI & -- & OSI & อ[०पM & & $\angle Z \angle S-\downarrow \varepsilon 68$ \\
\hline$S^{\prime} 60 \mathrm{I}$ & OZI & 66 & गे०पM & & LZLS-EE6\& \\
\hline \%1, & 4 & (1) & $g$ & (2) & (2) \\
\hline 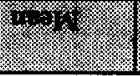 & $\frac{1}{2+2}$ & (1) & (1) & 4 & 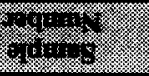 \\
\hline
\end{tabular}

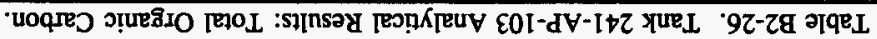




\begin{tabular}{|c|c|c|c|c|c|}
\hline $0 t t$ & -- & $0+t$ & गОपМ & \multirow[b]{2}{*}{82 Iอs!̣ } & $t+6 \mathrm{~d}$ \\
\hline$\$ 99$ & -- & \$99 & ग०ЧМ & & Et6d \\
\hline $000^{\circ} \mathrm{I}$ & - & $000^{\prime} \mathrm{I}$ & गО५М & \multirow[b]{4}{*}{$L Z$ Iəs!̣ } & $z+68$ \\
\hline $0 Z L$ & - & $0 Z 2$ & गОЧМ & & It68 \\
\hline$\$ 89$ & -- & $\$ 89$ & ว०ЧМ & & LE68 \\
\hline 099 & -- & 099 & गО्पМ & & $9 \varepsilon 68$ \\
\hline SSS & -- & SSS & ग०४М & \multirow[b]{4}{*}{ I resty } & St68 \\
\hline OZL & $\cdots$ & $0 Z L$ & गО५М & & $\downarrow \varepsilon 68$ \\
\hline 568 & -- & S68 & әГОЧМ & & £\&6ष \\
\hline $0<6$ & $\cdots$ & $0 \angle 6$ & ә૦ЧМ & & SE68 \\
\hline 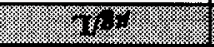 & 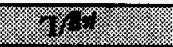 & 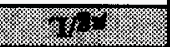 & 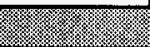 & (1) & 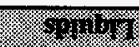 \\
\hline (2) & 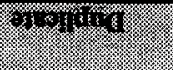 & $\sqrt[3]{40 \%}$ & 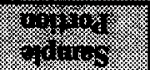 & 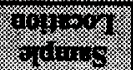 & 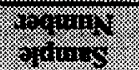 \\
\hline
\end{tabular}

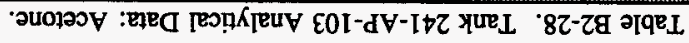

pojoen? $20 \mathrm{~N}=\mathrm{aN}_{\mathrm{N}}$

:องON

\begin{tabular}{|c|c|c|c|}
\hline$\cdots$ & - & aN & วurdoIdoso[पग!ब- $Z^{6}$ I \\
\hline QN & ([घ101) әuә $K X$ & aN & 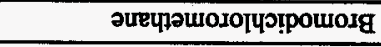 \\
\hline GN & วนวIא1S & $\mathbf{a N}$ & 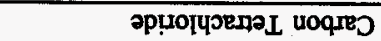 \\
\hline $9 \%$ & 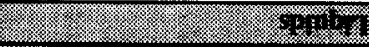 & 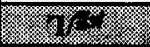 & $(x+2)$ \\
\hline & $918+18$ & 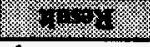 & $1 \% 1 \%$ \\
\hline
\end{tabular}

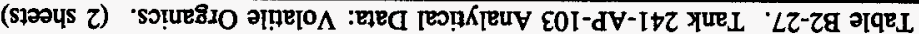


Table B2-29. Tank 241-AP-103 Analytical Data: Semivolatile Organics.

\begin{tabular}{|c|c|c|c|}
\hline (91) & $3(20 \times 1)$ & 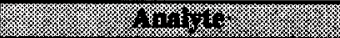 & (5t) \\
\hline WWD: & 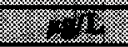 & 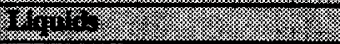 & 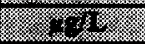 \\
\hline Phenol & ND & Acenaphthene & ND \\
\hline bis(2-Chloroethyl)ether & ND & 2,4-Dinitrophenol & ND \\
\hline 2-Chlorophenol & ND & 4-Nitrophenol & ND \\
\hline 1,3-Dichlorobenzene & ND & Dibenzofuran & ND \\
\hline 1,4-Dichlorobenzene & ND & 2,4-Dinitrotoluene & ND \\
\hline 1,2-Dichlorobenzene & ND & Diethylphthalate & ND \\
\hline 2-Methylphenol & ND & 4-Chlorophenyl-phenylether & ND \\
\hline 2,2'-oxybis(1-Chloropropane) & ND & Fluorene & ND \\
\hline 4-Methylphenol & $\mathrm{ND}$ & 4-Nitroaniline & ND \\
\hline N-Nitroso-di-n-propylamine & $\overline{\mathrm{ND}}$ & 4,6-Dinitro-2-methylphenol & ND \\
\hline Hexachloroethane & $\overline{\mathrm{ND}}$ & N-Nitrosodiphenylamine (1) & ND \\
\hline Nitrobenzene & ND & 4-Bromophenyl-phenylether & ND \\
\hline Isophorone & ND & Hexachlorobenzene & ND \\
\hline 2-Nitrophenol & $\overline{\mathrm{ND}}$ & Pentachlorophenol & ND \\
\hline 2,4-Dimethylphenol & ND & Phenanthrene & ND \\
\hline bis(2-Chloroethoxy)methane & ND & Anthracene & ND \\
\hline 2,4-Dichlorophenol & $\overline{\mathrm{ND}}$ & Carbazole & $\overline{\mathrm{ND}}$ \\
\hline 1,2,4-Trichlorobenzene & $\overline{\mathrm{ND}}$ & Di-n-butylphthalate & $\overline{\mathrm{ND}}$ \\
\hline Naphthalene & ND & Fluoranthene & ND \\
\hline 4-Chloroaniline & ND & Pyrene & ND \\
\hline Hexachlorobutadiene & ND & Butylbenzylphthalate & ND \\
\hline 4-Chloro-3-methylphenol & ND & 3,3'-Dichlorobenzidine & ND \\
\hline 5-Methylnaphthalene & ND & Benzo(a)anthracene & $\mathrm{ND}$ \\
\hline Hexachlorocyclopentadiene & ND & Chrysene & ND \\
\hline 2,4,6-Trichlorophenol & ND & bis(2-Ethylexyl)phthalate & ND \\
\hline 2,4,5-Trichlorophenol & ND & Di-n-octylphthalate & ND \\
\hline 2-Chloronaphthalene & $\overline{\mathrm{ND}}$ & Benzo(b)fluoranthene & ND \\
\hline 2-Nitroaniline & ND & Benzo(k)fluoranthene & ND \\
\hline Dimethylphthalate & ND & Benzo(a)pyrene & ND \\
\hline Acenaphthalate & ND & Indeno(1,2,3-cd)pyrene & $\mathrm{ND}$ \\
\hline 2,6-Dinitrotoluene & ND & Dibenz(a,h)anthracene & ND \\
\hline 3-Nitroaniline & ND & Benzo $(\mathrm{g}, \mathrm{h}, \mathrm{i})$ perylene & ND \\
\hline
\end{tabular}

Note:

$$
\text { ND }=\text { Not Detected }
$$




\begin{tabular}{|c|c|c|c|c|c|}
\hline $25600^{\circ} 0>$ & $68600^{\circ} 0>$ & $S I 600^{\circ} 0>$ & วl!soduo & VN Iəs!̣ & $0 \mathcal{E} \angle S-6 \downarrow 6 \mathbb{d}$ \\
\hline $29800^{\circ} 0>$ & $\cdots$ & $29800^{\circ} 0>$ & әОपМ & \multirow[b]{2}{*}{82 IOS!Y } & $8 Z \angle S-\nabla \downarrow 6 \mathbb{Z}$ \\
\hline$\angle \mathrm{L} 600^{\circ} 0>$ & $-\cdots$ & $\angle I 600^{\circ} 0>$ & गО्पМ & & E†68 \\
\hline$\varepsilon+600^{\circ} 0>$ & $\cdots$ & $\varepsilon \nabla 600^{\circ} 0>$ & әООЧМ & \multirow[b]{4}{*}{$\angle Z$ Iaș̣ } & $z \triangleright 6 \mathrm{~d}$ \\
\hline ZEOLI0 $0>$ & $\angle 0100>$ & $\nabla 6600^{\circ} 0>$ & әООЧМ & & $0 E L S-I \nabla 68$ \\
\hline $2 \varepsilon 800^{\circ} 0>$ & $\cdots$ & $z \varepsilon 800^{\circ} 0>$ & วОЧМ & & $\angle E 68$ \\
\hline$\nabla 6600^{\circ} 0>$ & $\cdots$ & $\nabla 6600^{\circ} 0>$ & әО्पМ & & $9 \varepsilon 68$ \\
\hline EII0.0 > & -- & EIIO० $>$ & गо्М & \multirow[b]{4}{*}{ I Iәsț } & St68 \\
\hline $69600^{\circ} 0>$ & -- & $69600^{\circ} 0>$ & ग्पू M & & SE6ष्ठ \\
\hline $7010^{\circ} 0>$ & $\cdots$ & $60100>$ & әрочМ & & $0 \mathcal{E} \angle S-\downarrow \mathcal{E} 6 \mathbb{d}$ \\
\hline IOOZII0.0 > & $t 2 z 0^{\circ} 0>$ & LO-BOII'I $>$ & ग0पМ & & $0 \mathcal{L} L S-\varepsilon \varepsilon 6 \mathbb{d}$ \\
\hline 1 14 & 1w14 & 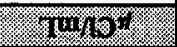 & & & spong \\
\hline (184) & 9101010 & 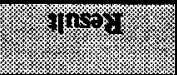 & 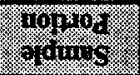 & 40 & oforing \\
\hline
\end{tabular}

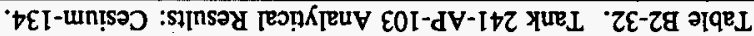

\begin{tabular}{|c|c|c|c|c|c|}
\hline$\$ 9 \$ 600>$ & $9+60^{\circ} 0>$ & $\angle 960^{\circ} 0>$ & 21!̣oduros & VN Iəsty & $0 \varepsilon \angle S-6 t 68$ \\
\hline$\angle I I^{\circ} O>$ & --- & $\angle I^{\circ} O>$ & $M$ & $\angle Z$ & $2 \not 68$ \\
\hline $8414 \%$ & 1116 & 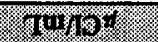 & & & 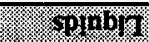 \\
\hline $1 \%$ & singoring & $1100 \%$ & 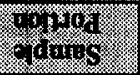 & $\frac{1110}{4010}$ & 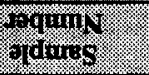 \\
\hline
\end{tabular}

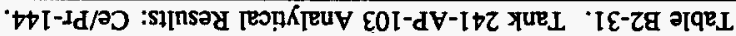

\begin{tabular}{|c|c|c|c|c|c|}
\hline $000^{\prime} \mathrm{CI}$ & $-\cdots$ & $000^{\prime} \mathrm{ZI}$ & ә0प $M$ & \multirow[b]{2}{*}{$8 Z$ دəs!̣ } & 1768 \\
\hline $000^{\prime} 29$ & -- & $000^{\prime} 29$ & शОЧМ & & Et6d \\
\hline $006^{\prime} 6$ & -- & $006^{4} 6$ & गОЧМ & \multirow[b]{3}{*}{$L Z$ Iasty } & 2768 \\
\hline $000^{\circ} 0 z$ & $\cdots$ & $000^{\prime} 0 z$ & गОपМ & & It $6 \mathrm{~d}$ \\
\hline $00 S^{6} s$ & -- & $00 S^{\prime} s$ & ग०पМ & & $\angle E 6 \mathrm{~d}$ \\
\hline 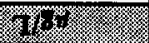 & $4 \%$ & $y \%$ & & & (2) \\
\hline 11,4 & 190) & $1 \%$ & 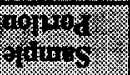 & 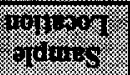 & ofingsing \\
\hline
\end{tabular}

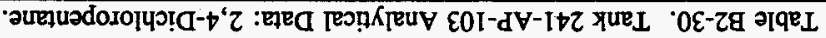


Table B2-33. Tank 241-AP-103 Analytical Results: Cesium-137.

\begin{tabular}{|c|c|c|c|c|c|}
\hline $\begin{array}{l}\text { Simplos } \\
\text { timner }\end{array}$ & 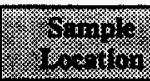 & - & I. & 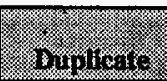 & 10 \\
\hline Wring & (1) & (5) & (1) & (c) & 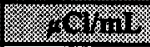 \\
\hline R933-5730 & \multirow[t]{4}{*}{ Riser 1} & Whole & 7.07 & 6.88 & 6.975 \\
\hline R934-5730 & & Whole & 7.2 & $\cdots$ & 7.2 \\
\hline R935 & & Whole & 5.8 & $\mid--$ & 5.8 \\
\hline R945 & & Whole & 4.23 & -- & 4.23 \\
\hline R936 & \multirow[t]{4}{*}{ Riser 27} & Whole & 7.02 & $\cdots$ & 7.02 \\
\hline R937 & & Whole & 6.59 & -- & 6.59 \\
\hline R941-5730 & & Whole & 6.41 & 6.42 & 6.415 \\
\hline R942 & & Whole & 8.5 & - & 8.5 \\
\hline R943 & \multirow[t]{2}{*}{ Riser 28} & Whole & 6.59 & -- & 6.59 \\
\hline R944-5728 & & Whole & 6.93 & -- & 6.93 \\
\hline R949-5730 & Riser NA & Composite & 6.03 & 5.99 & 6.01 \\
\hline
\end{tabular}

Table B2-34. Tank 241-AP-103 Analytical Results: Cobalt-60.

\begin{tabular}{|c|c|c|c|c|c|}
\hline $\begin{array}{l}\text { Sample } \\
\text { Vumber }\end{array}$ & $\begin{array}{l}\text { Shinple } \\
\text { Sodition }\end{array}$ & $\begin{array}{l}\text { Goringe } \\
\text { gorion. }\end{array}$ & Mesuin & Bingliting & 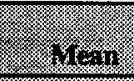 \\
\hline Mrguids: & (2) & Th & Mini. & Exinu & ( $86 \mathrm{mi}$ \\
\hline R945 & Riser 1 & Whole & $<0.011$ & $\ldots$ & $<0.011$ \\
\hline R942 & Riser 27 & Whole & $<0.01$ & -- & $<0.01$ \\
\hline R944-5728 & Riser 28 & Whole & $<0.012$ & - & $<0.012$ \\
\hline R949-5730 & Riser NA & Composite & $<0.0096$ & $<0.00932$ & $<0.00946$ \\
\hline
\end{tabular}

Table B2-35. Tank 241-AP-103 Analytical Results: Eu-154/155.

\begin{tabular}{|c|c|c|c|c|c|}
\hline $\begin{array}{l}\text { Sample } \\
\text { Vumber }\end{array}$ & $\begin{array}{l}\text { Sample } \\
\text { Socarion }\end{array}$ & $\begin{array}{l}\text { Somple: } \\
\text { rorion. }\end{array}$ & Resin & Brplisance & Wain \\
\hline Wigurds: & 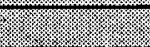 & U: & 161.01 & I enn & (1) knin \\
\hline R942 & Riser 27 & Whole & $<0.022$ & -- & $<0.022$ \\
\hline R944-5728 & Riser 28 & Whole & $<0.032$ & -- & $<0.032$ \\
\hline
\end{tabular}


HNF-SD-WM-ER-359, Rev. 1

Table B2-36. Tank 241-AP-103 Analytical Results: Europium-154.

\begin{tabular}{|c|c|c|c|c|c|}
\hline 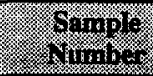 & 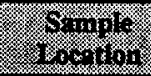 & 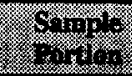 & 3 & S4) & 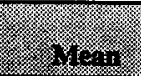 \\
\hline ming & (2) & (2) & (1) & 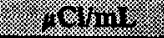 & 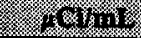 \\
\hline R945 & Riser 1 & Whole & $<0.032$ & $\ldots$ & $<0.032$ \\
\hline R949-5730 & Riser NA & Composite & $<0.0248$ & $<0.0271$ & $<0.02595$ \\
\hline
\end{tabular}

Table B2-37. Tank 241-AP-103 Analytical Results: Europium-155.

\begin{tabular}{|c|c|c|c|c|c|}
\hline Plon & 40.101010 & (6) & insin. & 8,401181 & (1) \\
\hline riginis & \% & 2) & F. & (6) & (3) \\
\hline R933-5730 & \multirow[t]{3}{*}{ Riser 1} & Whole & $<4.330$ E-07 & $<0.0875$ & $<0.0437502$ \\
\hline R934-5730 & & Whole & $<0.0521$ & -- & $<0.0521$ \\
\hline R935 & & Whole & $<0.0483$ & -- & $<0.0483$ \\
\hline R936 & \multirow[t]{3}{*}{ Riser 27} & Whole & $<0.05$ & -- & $<0.05$ \\
\hline R937 & & Whole & $<0.0502$ & $\cdots$ & $<0.0502$ \\
\hline R941-5730 & & Whole & $<0.026$ & $<0.026$ & $<0.026$ \\
\hline R943 & Riser 28 & Whole & $<0.0474$ & - & $<0.0474$ \\
\hline R949-5730 & Riser NA & Composite & $<0.0252$ & $<0.0255$ & $<0.02535$ \\
\hline
\end{tabular}

Table B2-38. Tank 241-AP-103 Analytical Results: Niobium-94.

\begin{tabular}{|c|c|c|c|c|c|}
\hline 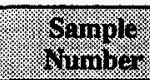 & 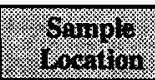 & - $6.901 \%$ & 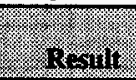 & (8) & (c) \\
\hline Trouns & 8 & 3. & 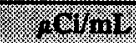 & 40111 & 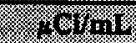 \\
\hline R942 & Riser 27 & Whole & $<0.0093$ & -- & $<0.0093$ \\
\hline
\end{tabular}

Table B2-39. Tank 241-AP-103 Analytical Results: Niobium-95.

\begin{tabular}{|c|c|c|c|c|c|}
\hline $\sin 10$ & $90 \% 11$ & 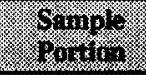 & 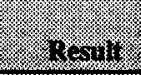 & 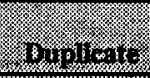 & 14 \\
\hline Mrous & & 3. & 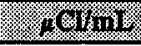 & r $6 / 11$ & $4 \%$ \\
\hline R949-5730 & Risèr NA & Composite & $<0.0784$ & $<0.00825$ & $<0.008045$ \\
\hline
\end{tabular}


Table B2-40. Tank 241-AP-103 Analytical Results: Radium-226.

\begin{tabular}{|c|c|c|c|c|c|}
\hline 1. & 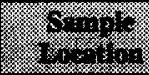 & 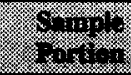 & $(5,1)$ & $3.315 \times$ & $8 \%$ \\
\hline $6 \times 1 ;$ & 2ris & ২ু & (2) & \% & . \\
\hline R942 & Riser 27 & Whole & $<0.043$ & -- & $<0.043$ \\
\hline R949-5730 & Riser NA & Composite & $<0.247$ & $<0.241$ & $<0.244$ \\
\hline
\end{tabular}

Table B2-41. Tank 241-AP-103 Analytical Results: Ruthenium/Rhodium-106.

\begin{tabular}{|c|c|c|c|c|c|}
\hline 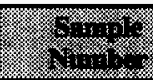 & $\int_{1}$ & 等 & (3) & 3.1.1. & 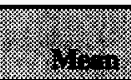 \\
\hline 6ens & $\checkmark$ & & 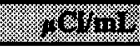 & (1) & (1) \\
\hline R942 & Riser 27 & Whole & $<0.34$ & -- & $<0.34$ \\
\hline R949-5730 & Riser NA & Composite & $<0.189$ & $<0.195$ & $<0.192$ \\
\hline
\end{tabular}

Table B2-42. Tank 241-AP-103 Analytical Results: Tin-113.

\begin{tabular}{|c|c|c|c|c|c|}
\hline (5) & 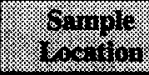 & 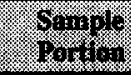 & $5<-11$ & 38101\% & 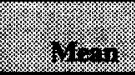 \\
\hline 13 & 諼 & & 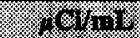 & 3) & 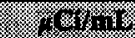 \\
\hline R942 & Riser 27 & Whole & $<0.03$ & -- & $<0.03$ \\
\hline R949-5730 & Riser NA & Composite & $<0.0176$ & $<0.0176$ & $<0.0176$ \\
\hline
\end{tabular}

Table B2-43. Tank 241-AP-103 Analytical Results: Iodine-129.

\begin{tabular}{|c|c|c|c|c|c|}
\hline 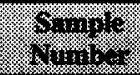 & 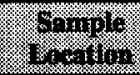 & 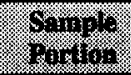 & $2, \cdots 11$ & 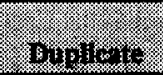 & $83=13$ \\
\hline 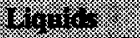 & & & 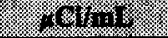 & $\left.(4)_{11}\right)=$ & $4^{2}$ \\
\hline R949-5785 & Riser NA & Composite & $<3.030 \mathrm{E}-05$ & $<3.340 \mathrm{E}-05$ & $<3.185 \mathrm{E}-05^{\mathrm{QC}: \mathrm{b}}$ \\
\hline
\end{tabular}

Table B2-44. Tank 241-AP-103 Analytical Data: Uranium-234.

\begin{tabular}{|c|c|c|c|c|c|}
\hline$x_{1}^{6}$ & 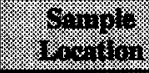 & $30 \%$ & $1+2+1$ & 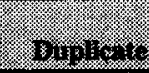 & 1 1- \\
\hline $2018=3$ & 䧻 & & $3,3,1$ & 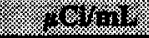 & $2 x$ \\
\hline R949 & Riser NA & Composite & $6.56 \mathrm{E}-06$ & -- & 6.56E-06 \\
\hline
\end{tabular}


Table B2-45. Tank 241-AP-103 Analytical Data: Uranium-235.

\begin{tabular}{|c|c|c|c|c|c|}
\hline 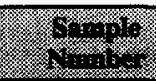 & 策, & 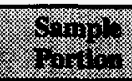 & $7.1 .11)$ & 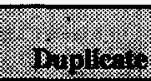 & 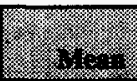 \\
\hline 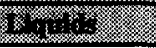 & V. & (1) & $x=3$ & \% & , \\
\hline R949 & Riser NA & Composite & 3.39E-07 & - & $3.39 \mathrm{E}-07$ \\
\hline
\end{tabular}

Table B2-46. Tank 241-AP-103 Analytical Data: Uranium-238.

\begin{tabular}{|c|c|c|c|c|c|}
\hline $4 \%$ & 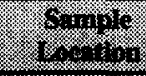 & 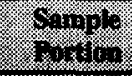 & 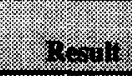 & $1040,13=$ & $4 \%$ \\
\hline $311 \%$ & & & (x) & 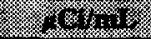 & $4 \%$ \\
\hline R949 & Riser NA & Composite & $1.26 \mathrm{E}-06$ & -- & $1.26 \mathrm{E}-06$ \\
\hline
\end{tabular}

Table B2-47. Tank 241-AP-103 Analytical Results: Americium-241.

\begin{tabular}{|c|c|c|c|c|c|}
\hline 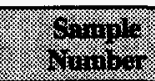 & 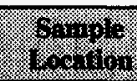 & 40 & 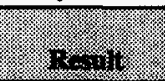 & B. & (4) \\
\hline 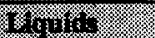 & & & (1) & (4) & 1914: \\
\hline R949-5781 & Riser NA & Composite & $<1.140 \mathrm{E}-05$ & $<1.130 \mathrm{E}-05$ & $<1.135 \mathrm{E}-05$ \\
\hline
\end{tabular}

Table B2-48. Tank 241-AP-103 Analytical Results: Plutonium-239/240.

\begin{tabular}{|c|c|c|c|c|c|}
\hline 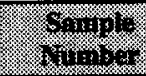 & 40 & (3) & $4 \%$ & 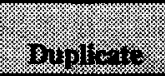 & 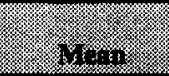 \\
\hline 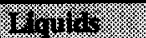 & & & ry ry & 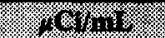 & 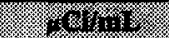 \\
\hline R949-5781 & Riser NA & Composite & $<6.970 \mathrm{E}-06$ & $<6.970 \mathrm{E}-06$ & $<6.970 \mathrm{E}-06$ \\
\hline
\end{tabular}

Table B2-49. Tank 241-AP-103 Analytical Results: Carbon-14.

\begin{tabular}{|c|c|c|c|c|c|}
\hline 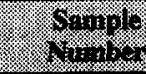 & 3. & 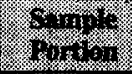 & 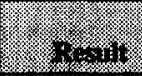 & $8,112: 16$ & 40,1 \\
\hline 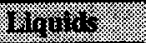 & & : & $101 \%$ & 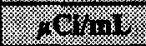 & $1.61=1$ \\
\hline R949-5788 & Riser NA & Composite & 6.330E-06 & $2.610 \mathrm{E}-06$ & 4.470E-06 QC:e \\
\hline
\end{tabular}

Table B2-50, Tank 241-AP-103 Analytical Results: Selenium-79.

\begin{tabular}{|c|c|c|c|c|c|}
\hline 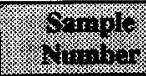 & $x_{1}^{6}$ & 2., & $4 \ln 4$ & $8+1319$ & 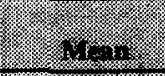 \\
\hline WFi: & & 媇 & moly & ( (6) & 1,6 \\
\hline R949-5789. & Riser NA & Composite & $1.320 \mathrm{E}-05$ & $9.100 \mathrm{E}-06$ & $1.115 \mathrm{E}-05^{\mathrm{QC}:}$ \\
\hline
\end{tabular}


Table B2-51. Tank 241-AP-103 Analytical Results: Tritium.

\begin{tabular}{|c|c|c|c|c|c|}
\hline O. & 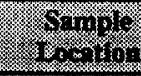 & 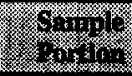 & 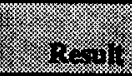 & solingis & 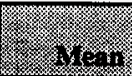 \\
\hline xinging. & 双 & (1) & $21 \%$ & 2014 & V. \\
\hline R949-5787 & Riser NA & Composite & 0.00523 & 0.00525 & 0.00524 \\
\hline
\end{tabular}

Table B2-52. Tank 241-AP-103 Analytical Results: Technetium-99.

\begin{tabular}{|c|c|c|c|c|c|}
\hline (2) & 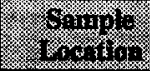 & 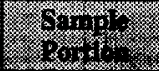 & is & $2+2013$ & \\
\hline tovirs & & (3) & (x) & $4 \ln _{313}$ & 28. \\
\hline R949-5784 & Riser NA & Composite & 0.00112 & 0.00104 & 0.00108 \\
\hline
\end{tabular}

Table B2-53. Tank 241-AP-103 Analytical Results: Total Uranium.

\begin{tabular}{|c|c|c|c|c|c|}
\hline 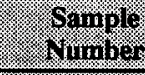 & somplos & 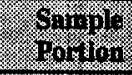 & 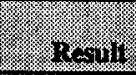 & 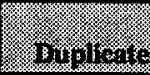 & 8,4 \\
\hline Writho & & & $2,48+13$ & \% & $4 \%$ \\
\hline R949-5740 & Riser NA & Composite & 3.9 & 3.48 & 3.69 \\
\hline
\end{tabular}

Table B2-54. Tank 241-AP-103 Analytical Results: Strontium-90.

\begin{tabular}{|c|c|c|c|c|c|}
\hline $\begin{array}{l}\text { Sumple } \\
\text { Anmber }\end{array}$ & 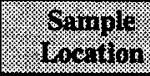 & Soring & $6 \operatorname{sen} 11$ & 61011428 & 445 \\
\hline Wquids & & & 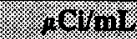 & 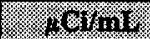 & 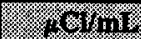 \\
\hline R949-5786 & Riser NA & Composite & 0.00262 & 0.00262 & 0.00262 \\
\hline
\end{tabular}


Table B2-55. Tank 241-AP-103 Analytical Results: Specific gravity.

\begin{tabular}{|c|c|c|c|c|c|}
\hline $\begin{array}{l}\text { Sample } \\
\text { Vimons }\end{array}$ & S Surnoplo: & Somp & (3) & 1, & 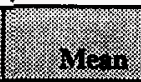 \\
\hline Thanits & ) & (- & (2) yniries & 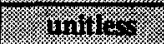 & I vinil \\
\hline R933-5706 & \multirow[t]{4}{*}{ Riser 1} & Whole & 0.995 & 1.00 & 0.9975 \\
\hline R934-5706 & & Whole & 1.01 & - & 1.01 \\
\hline R935 & & Whole & 1.018 & $-\cdots$ & 1.018 \\
\hline R945 & & Whole & 1.01 & -- & 1.01 \\
\hline R936 & \multirow[t]{4}{*}{ Riser 27} & Whole & 1.002 & - & 1.002 \\
\hline R937 & & Whole & 1.017 & - & 1.017 \\
\hline R941-5706 & & Whole & 0.995 & 0.995 & 0.995 \\
\hline R942 & & Whole & 1.0044 & -- & 1.0044 \\
\hline R943 & \multirow[t]{2}{*}{ Riser 28} & Whole & 0.992 & - & 0.992 \\
\hline R944 & & Whole & 0.994 & $\ldots$ & 0.994 \\
\hline
\end{tabular}

\section{B2.7 HISTORICAL SAMPLE RESULTS}

Prior to the 1991 sampling event, the most recent sampling of tank 241-AP-103 occurred in April 1988. Because multiple waste transfers have occurred since this last sampling event, no valid comparison between the sampling events can be made. 


\section{B3.0 ASSESSMENT OF CHARACTERIZATION RESULTS}

The purpose of this chapter is to discuss the overall quality and consistency of the 1991 sampling results for tank 241-AP-103. This section also evaluates sampling and analysis factors that may impact interpretation of the data. These factors are used to assess the overall quality and consistency of the data and to identify any limitations in the use of the data.

\section{B3.1 FIELD OBSERVATIONS}

The safety screening DQO requirement that at least two widely spaced risers be sampled was fulfilled, allowing a horizontal comparison of the analytical results. Sample 3AP891-3 was resampled and replaced by sample 3AP1191-1 because the custody seal was improperly attached.

\section{B3.2 QUALITY CONTROL ASSESSMENT}

The usual quality control assessment includes an evaluation of the appropriate standard recoveries, spike recoveries, duplicate analyses, and blanks that are performed in conjunction with the chemical analyses. All the pertinent quality control tests were conducted on the 1991 grab samples, allowing a full assessment regarding the accuracy and precision of the data. Samples that had one or more QC results outside the specified criteria were identified by footnotes in the data summary tables.

The standard and matrix spike recovery results provide an estimate of the accuracy of the analysis. If a standard or spike recovery is above or below the given criterion then the analytical results may be biased high or low, respectively. Arsenic, iron, and nitrite had recoveries that were outside the given limits. The poor spike result for nitrite may have been caused by the use of an inappropriate spiking concentration relative to the sample concentration. The analytical precision is estimated by the relative percent difference (RPD), which is defined as the absolute value of the difference between the primary and duplicate samples, divided by their mean, multiplied by one hundred. Iron, Manganese, $\mathrm{Zinc},{ }^{14} \mathrm{C}$, and ${ }^{79} \mathrm{Se}$ each had duplicates which exceeded the defined limit.

In summary, the vast majority of the QC results were within the specified boundaries. The discrepancies mentioned here and footnoted in the data summary tables should not impact either the validity or the use of the data. 


\section{B3.3 DATA CONSISTENCY CHECKS}

Comparisons of different analytical methods can help to assess the consistency and quality of the data. The quantity of data from the grab sampling event made possible the calculation of mass and charge balances, along with the comparison between total uranium by alpha proportional counting and total uranium from isotopic data.

\section{B3.3.1 Comparison of Results from Different Analytical Methods}

The following data consistency check compares the results from two different analytical methods for uranium. A close correlation between the two methods strengthens the credibility of both results, whereas a poor correlation brings the reliability of the data into question. All mean results were taken from tables in Section B2. Other standard checks, such as comparing sulfate and phosphate analyses by IC analyses and ICP estimates or comparing total alpha with ${ }^{239240} \mathrm{Pu}$ and ${ }^{241} \mathrm{Am}$ isotope analyses, were not possible due to data limitations.

The total uranium value from alpha proportional counting was $3,690 \mu \mathrm{g} / \mathrm{L}$. This compared well with the total uranium from isotopic results of $3,900 \mu \mathrm{g} / \mathrm{L}$. The comparison is presented in Table B3-1.

Table B3-1. Comparison of Total Uranium Results from Different Analytical Methods.

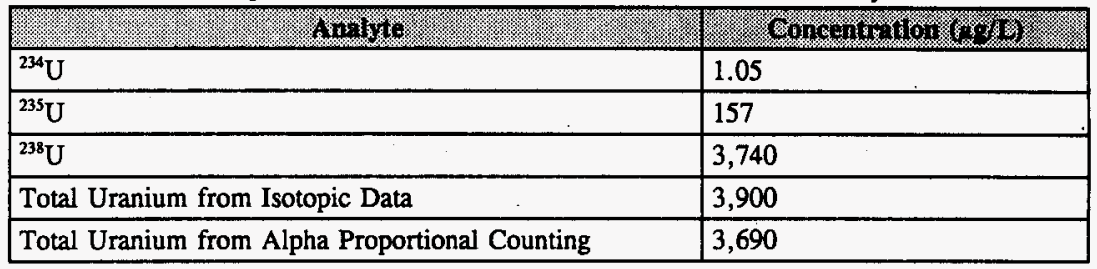

\section{B3.3.2 Mass and Charge Balance}

The principle objective in performing mass and charge balances is to determine if the measurements were consistent. It also provides a method of estimating the weight percent water in the tank, since it was not determined by the laboratory. In calculating the balances, only analytes listed in Section B2 detected at a concentration of $1 \mu \mathrm{g} / \mathrm{g}$ or greater were considered. 
The cation and anion results are shown in Table B3-2 and Table B3-3, respectively. Examination of the data revealed an excess negative charge, as shown in Table B3-4. The net charge balance was 89 percent, with an excess negative charge. This indicates that some cations, such as potassium or calcium, may not be accounted for in the analyses. Although some analytes may not be fully accounted for, these are expected to be minor contributions to the overall mass balance.

As shown in Table B3-4, the total analyte concentration was $15,740 \mu \mathrm{g} / \mathrm{g}$ and was subtracted from $1,000,000 \mu \mathrm{g} / \mathrm{g}$ to obtain an estimated value for the weight percent water. In other words, mass not accountable to the analyte concentrations is attributed to water. The tank is estimated to contain approximately 98.4 percent water.

Table B3-2. Cation Mass and Charge Data.

\begin{tabular}{|c|c|c|c|}
\hline \multirow[b]{2}{*}{$3,5,15 \%$} & \multirow{2}{*}{ 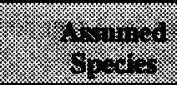 } & 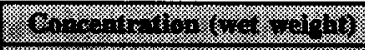 & \multirow{2}{*}{ 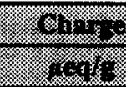 } \\
\hline & & 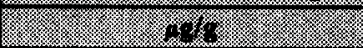 & \\
\hline Aluminum & $\mathrm{Al}^{3+}$ & 247 & 27.4 \\
\hline Chromium & $\mathrm{Cr}^{6+}$ & 4.36 & 0.503 \\
\hline Sodium & $\mathrm{Na}^{+}$ & 5,280 & 230 \\
\hline Uranium & $\mathrm{U}^{6+}$ & 3.69 & 0.0930 \\
\hline Total & & 5,540 & 258 \\
\hline
\end{tabular}

Table B3-3. Anion Mass and Charge Data.

\begin{tabular}{|c|c|c|c|}
\hline \multirow[b]{2}{*}{ 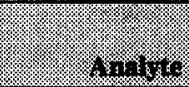 } & \multirow{2}{*}{$x_{0}$} & 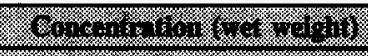 & \multirow{2}{*}{ 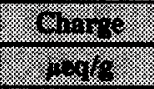 } \\
\hline & & $x_{2}$ & \\
\hline Chloride & $\mathrm{Cl}^{-}$ & 50.9 & 1.44 \\
\hline Fluoride & $\mathbf{F}^{-}$ & 134 & 7.05 \\
\hline Hydroxide & $\mathrm{OH}^{-}$ & 1,520 & 89.4 \\
\hline Nitrate & $\mathrm{NO}_{3}^{-}$ & 4,080 & 65.8 \\
\hline Nitrite & $\mathrm{NO}_{2}^{-}$ & 1,300 & 28.3 \\
\hline Phosphate & $\mathrm{PO}_{4}{ }^{3-}$ & 138 & 4.36 \\
\hline Sulfate & $\mathrm{SO}_{4}{ }^{2-}$ & 362 & 7.54 \\
\hline TIC & $\mathrm{CO}_{3}{ }^{2-}$ & 2,600 & 86.7 \\
\hline Total & & 10,200 & 291 \\
\hline
\end{tabular}


Table B3-4. Charge Balance and Calculation of Weight Percent Water.

\begin{tabular}{|l|l|l|}
\hline & \multicolumn{2}{|c|}{ (1) } \\
\hline & & \\
\hline Total from Table B3-2 & 5,540 & 258 \\
\hline Total from Table B3-3 & 10,200 & 291 \\
\hline Percent water (est.) & 984,000 & N/A \\
\hline
\end{tabular}

\section{B3.4 CALCULATION OF ANALYTICAL BASED MEANS AND INVENTORY}

The following evaluation was performed on the analytical data from the grab samples from double-shell tank 241-AP-103. The statistical analysis and inventory estimates are used to support the characterization best-basis inventory given in Appendix D.

In addition to the mean, two-sided 95 percent confidence intervals on the mean inventory are computed.

The lower limit (LL) to a two-sided 95 percent confidence interval for the mean is

$$
L L=\hat{\mu}-t_{(d, 0.02 s)} \times \sqrt{\sigma^{2}}
$$

and the upper limit (UL) to a two-sided 95 percent confidence interval for the mean is

$$
U L=\hat{\mu}+t_{(\alpha, 0.025)} \times \sqrt{\sigma^{2}} .
$$

In these equations, $\hat{\mu}$ is the estimate of the mean concentration, $\sigma_{\hat{\alpha}}^{2}$ is the estimate of the variance of the mean concentration, and $t_{(a f, 0.025)}$ is the quantile from the student $t$ distribution with $d f$ degrees of freedom for a two-sided 95 percent confidence interval.

The mean, $\hat{\mu}$, and the variance, $\sigma_{\hat{\mu}}^{2}$, were estimated using restricted maximum likelihood estimation (REML) methods. The degrees of freedom (df) for tank 241-AP-103 are the number of locations sampled minus one (i.e., one sample location for R933-8750 result and duplicate; samples R930 and R941-8750 [result and duplicate] were obtained from the same location). 
Table B3-5 gives the upper and lower limits to the 95 percent confidence intervals on the mean for analytes detected in tank 241-AP-103. Some analytes had a.computed lower limit less than 0 . Because a concentration estimate less than 0 is not possible, the lower limit was recorded as 0 whenever the lower limit was negative.

Table B3-5. 95 Percent Two-Sided Confidence Interval for the Mean Concentration.

\begin{tabular}{|c|c|c|c|c|c|}
\hline 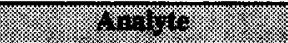 & \% & 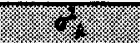 & 1. & \% & 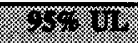 \\
\hline Aluminum $(\mu \mathrm{g} / \mathrm{L})$ & $2.47 \mathrm{E}+05$ & $4.03 E+06$ & 8 & $1.00 \mathrm{E}+05$ & $3.93 E+05$ \\
\hline Arsenic $(\mu \mathrm{g} / \mathrm{mL})$ & 0.0485 & $3.10 \mathrm{E}-05$ & 8 & 0.0357 & 0.0613 \\
\hline Cadmium $(\mu \mathrm{g} / \mathrm{mL})$ & 109 & 269 & 8 & 71.4 & 147 \\
\hline Chromium $(\mu \mathrm{g} / \mathrm{L})$ & 4,360 & $2.39 \mathrm{e}+05$ & 8 & 3,230 & 5,490 \\
\hline Cyanide $^{1}(\mu \mathrm{g} / \mathrm{mL})$ & 0.601 & 0.00273 & 8 & 0.480 & 0.722 \\
\hline $\operatorname{Iron}^{1}(\mu \mathrm{g} / \mathrm{L})$ & 837 & 51,900 & 8 & 610 & 2,430 \\
\hline Magnesium $^{1}(\mu \mathrm{g} / \mathrm{L})$ & 714 & 21,700 & 8 & 374 & 1,050 \\
\hline Manganese $^{1}(\mu \mathrm{g} / \mathrm{L})$ & 29.8 & 58.8 & 8 & 12.1 & 47.5 \\
\hline Sodium $(\mu \mathrm{g} / \mathrm{L})$ & $5.28 \mathrm{E}+06$ & $9.60 \mathrm{E}+11$ & 8 & $3.02 E+06$ & $7.54 \mathrm{E}+06$ \\
\hline $\operatorname{Zinc}^{1}(\mu \mathrm{g} / \mathrm{L})$ & 285 & 17,000 & 8 & 0 & 586 \\
\hline Chloride $(\mu \mathrm{g} / \mathrm{mL})$ & 50.9 & 72.8 & 8 & 31.2 & 70.6 \\
\hline Fluoride $(\mu \mathrm{g} / \mathrm{mL})$ & 134 & 913 & 8 & 64.1 & 204 \\
\hline Hydroxide $(\mu \mathrm{g} / \mathrm{mL})$ & 1,520 & $1.56 \mathrm{E}+05$ & 8 & 610 & 2,430 \\
\hline Nitrate $(\mu \mathrm{g} / \mathrm{mL})$ & 4,080 & $1.17 \mathrm{E}+06$ & 8 & 1,580 & 6,570 \\
\hline Nitrite $(\mu \mathrm{g} / \mathrm{mL})$ & 1,300 & 8,700 & 8 & 1,090 & 1,520 \\
\hline Phosphate $(\mu \mathrm{g} / \mathrm{mL})$ & 138 & 30.3 & 8 & 125 & 151 \\
\hline Sulfate $(\mu \mathrm{g} / \mathrm{mL})$ & 362 & 1,440 & 8 & 275 & 450 \\
\hline $\mathrm{TIC}(\mu \mathrm{gC} / \mathrm{mL})$ & 520 & 436 & 8 & 472 & 568 \\
\hline $\mathrm{TOC}(\mu \mathrm{gC} / \mathrm{mL})$ & 110 & 45.1 & 8 & 94.6 & 126 \\
\hline Cesium-137 $(\mu \mathrm{Ci} / \mathrm{L})$ & 6,640 & $1.48 \mathrm{E}+05$ & 8 & 5,750 & 7,520 \\
\hline SpG & 1.00 & $7.00 \mathrm{E}-06$ & 8 & 0.997 & 1.01 \\
\hline
\end{tabular}

Note:

'Some "less-than detection" values are included in the mean calculation. 
A statistical model is needed to account for the spatial and measurement variability in $\sigma_{\hat{\hat{\mu}}}^{2}$. This cannot be done using an ordinary standard deviation of the data.(Snedecor and Cochran 1980).

The statistical model used to describe the structure of the data is

$$
\begin{gathered}
Y_{i j k}=\mu+L_{i}+A_{i j}, \\
i=1, \ldots, a, j=1, \ldots, n_{i},
\end{gathered}
$$

where

$$
\begin{aligned}
& Y_{i j}=\quad \text { laboratory results from the } k^{\text {th }} \text { duplicate from the } i^{\text {th }} \text { location in the tank, } \\
& \mu \quad \text { the grand mean } \\
& L_{i}=\text { the effect of the } i^{\text {th }} \text { location (measuring spatial variability) } \\
& A_{i j}=\text { the effect of the } j^{\text {th }} \text { analytical result from the } i^{\text {th }} \text { location (measurement } \\
& a \quad=\quad \text { the number of sample locations } \\
& n_{i}=\text { the number of analytical results from the } i^{\text {th }} \text { location. }
\end{aligned}
$$

The variable $L_{i}$ is assumed to a random effect. This variable, as well as $A_{i j}$, are assumed to be uncorrelated and normally distributed with means zero and variances $\sigma^{2}(L)$ and $\sigma^{2}(A)$, respectively. Estimates of $\sigma^{2}(\mathrm{~L})$ and $\sigma^{2}(\mathrm{~A})$ were obtained using REML techniques. This method, applied to variance component estimation, is described in Harville (1977). The results using the REML techniques were obtained using the statistical analysis package S-PLUS (StatSci 1993).

Confidence intervals could not be performed on the DSC data, because all of the results were zero.

After the REML sample means are estimated for the tank for each analyte, the sampling based inventory may be calculated. Because the analyte concentrations above are presented in terms of a mass basis concentration, the total mass of waste in the tank is needed to estimate inventories. The total mass of waste is derived from the tank volume (from surveillance). The total tank volume is $87 \mathrm{~kL}$ (23 kgal) (Hanlon 1996). The inventory of each of the analytes is presented in Appendix $\mathrm{D}$. 


\section{B4.0 APPENDIX B REFERENCES}

ASTM, 1973, "Weighted Bottle Method", ASTM E-300-73, American Society for Testing and Materials, Philadelphia, Pennsylvania.

Bell, K.E., 1994, Tank Waste Remediation System Tank Waste Analysis Plan, WHC-SD-WM-PLN-077, Rev. 0, Westinghouse Hanford Company, Richland, Washington.

DeLorenzo, D. S., J. H. Rutherford, D. J. Smith, D. B. Hiller, K. W. Johnson, and B. C. Simpson, 1994, Tank Characterization Reference Guide, WHC-SD-WM-TI-648, Rev. 0, Westinghouse Hanford Company, Richland, Washington.

EPA, 1991, Contract Laboratory Program Statement of Work, U.S. Environmental Protection Agency, Washington, D.C.

EPA, 1990, "Identification and Listing of Hazardous Wastes," 40 CFR 261, U.S. Environmental Protection Agency, Washington, D.C.

Halgren, D.L., 1991, Double-Shell Tank Waste Analysis Plan, WHC-SD-WM-EV-053, Rev. 1, Westinghouse Hanford Company, Richland, Washington.

Hanlon, B. M., 1996, Waste Tank Summary Report for Month Ending July 31, 1996, WHC-DP-0182-100, Westinghouse Hanford Company, Richland, Washington.

Harville, D. A., 1977, "Maximum Likelihood Approaches to Variance Component Estimation and to Related Problems," Journal of the American Statistical Association, pp. 320-340.

Snedecor, G. W., and W. G. Cochran, 1980, Statistical Methods, 7th Edition, Iowa State University Press, Ames, lowa.

StatSci, (a division of Mathsoft, Inc.), 1993, S-PLUS Reference Manual, Version 3.2, Statistical Sciences, Inc., Seattle, Washington.

Van Vleet, R.J., 1993, Radionuclide and Chemical Inventories for the Double-Shell Tanks, WHC-SD-WM-TI-543, Rev. 1, Westinghouse Hanford Company, Richland, Washington. 
HNF-SD-WM-ER-359, Rev, 1

Wehner, K. B., 1994, Semivolatile Analytical Results, T734, (internal memorandum to E. Q. Le, May 23), Westinghouse Hanford Company, Richland, Washington.

WHC, 1992, Summary Data Report, WHC-SD-WM-DP-025, Addendum 5A Rev. 0 to Addendum 14A Rev. 0, Westinghouse Hanford Company, Richland, Washington. 
HNF-SD-WM-ER-359, Rev. 1

\section{APPENDIX C}

STATISTICAL ANALYSIS FOR ISSUE RESOLUTION

C-1 
HNF-SD-WM-ER-359, Rev. 1

This page left blank intentionally. 


\section{APPENDIX C \\ STATISTICAL ANALYSIS FOR ISSUE RESOLUTION}

In Appendix C, the analyses required for the applicable data quality objective (DQO) reports for tank 241-AP-103 are performed. Specifically, statistical and other numerical manipulations required in the DQO reports are performed and documented in this appendix. The two analyses required for tank 241-AP-103 are documented in the following sections:

- Section C1: Statistical analysis and numerical manipulations supporting the Safety Screening DQO (Dukelow et al. 1995).

- Section C2: References for Appendix C.

\section{C1.0 STATISTICS FOR SAFETY SCREENING DQO}

The safety screening DQO (Dukelow et al. 1995) defines acceptable decision confidence limits in terms of one-sided 95 percent confidence intervals on the mean for each subsample. All of the anaiytes evaluated for the safety screening DQO were below the detection limit. As a result, the calculation of confidence intervals was not required.

\section{C2.0 APPENDIX C REFERENCES}

Dukelow, G. T., J. W. Hunt, H. Babad, and J. E. Meacham, 1995, Tank Safety Screening Data Quality Objective, WHC-SD-WM-SP-004, Rev. 2, Westinghouse Hanford Company, Richland, Washington. 
HNF-SD-WM-ER-359, Rev. 1

This page left blank intentionally. 


\section{APPENDIX D}

\section{EVALUATION TO ESTABLISHED BEST-BASIS INVENTORY FOR TANK 241-AP-103}


HNF-SD-WM-ER-359, Rev. 1

This page left blank intentionally. 


\section{APPENDIX D \\ EVALUATION TO ESTABLISH BEST-BASIS \\ INVENTORY FOR DOUBLE-SHELL TANK 241-AP-103}

An effort is underway to provide waste inventory estimates that will serve as standard characterization source terms for the various waste management activities

(Hodgson et al. 1996). As part of this effort, an evaluation of available chemical information for tank 241-AP-103 was performed, and a best-basis inventory was established. This work, detailed in the following sections, follows the methodology that was established by the standard inventory task.

The following evaluation provides a best-basis inventory estimate for chemical and radionuclide components in tank 241-AP-103.

Expected Waste Type

Dilute Noncomplexed (DN)

\section{D1.0 CHEMICAL INFORMATION SOURCES}

Available composition information for the waste in tank 242-AP-103 is as follows:

- Characterization results from the 1991 "bottle-on-a-string" sampling event.

- The HDW model document (Agnew et al. 1996). A complete list of data sources used in this evaluation is provided at the end of this section.

\section{D2.0 COMPARISON OF COMPONENT INVENTORY VALUES}

Sample-based inventories derived from 1991 analytical concentration data, and HDW model inventories generated by the HDW model (Agnew et al. 1996), are compared in Tables D2-1 and D2-2. Sample-based inventories derived for comparison with HDW values are based on a tank volume of $4,315 \mathrm{~kL}(1,140 \mathrm{kgal})$. This was the tank inventory in 1991 when samples were taken. The HDW model tank volume is slightly lower at $4,277 \mathrm{~kL}(1,130 \mathrm{kgal})$. The density calculated by the HDW model is $1.07 \mathrm{~g} / \mathrm{mL}$ compared to a mean analytical result of $1.00 \mathrm{~g} / \mathrm{mL}$.

During 1994, all but $87 \mathrm{~kL}$ (23 kgal) of the waste in tank 241-AP-103 was transferred to tank 241-AW-102 to be concentrated in the 242-A Evaporator. 
HNF-SD-WM-ER-359, Rev. 1

Table D2-1. Sampling and Hanford Defined Waste Model Inventory Estimates for Nonradioactive Components in DST 241-AP-103.

\begin{tabular}{|c|c|c|c|c|c|}
\hline (2. & 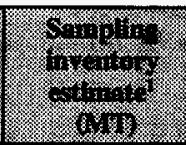 & 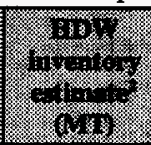 & (2. & 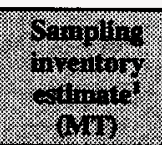 & 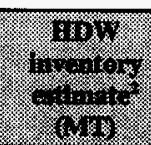 \\
\hline $\mathrm{Al}$ & 1.05 & 23.5 & $\mathrm{NO}_{3}$ & 17.3 & 23.5 \\
\hline As & 2.07E-04 & NR & $\mathrm{Ni}$ & NR & 0.285 \\
\hline $\mathrm{Ba}$ & $<2.78 \mathrm{E}-04$ & NR & $\mathrm{Pb}$ & 0.00171 & 0.475 \\
\hline $\mathrm{Be}$ & NR & NR & $\mathrm{Se}$ & $8.56 \mathrm{E}-05$ & NR \\
\hline B & NR & NR & $\mathrm{Si}$ & NR & 4.35 \\
\hline $\mathrm{Cd}$ & $4.75 \mathrm{E}-04$ & NR & $\mathrm{Ti}$ & NR & NR \\
\hline $\mathrm{Ca}$ & NR & 1.09 & $\mathrm{U}$ & 0.0158 & 5.41 \\
\hline $\mathrm{Ce}$ & NR & NR & $\mathrm{Zn}$ & 0.00189 & NR \\
\hline $\mathrm{Cr}$ & 0.0188 & 0.597 & $\mathrm{Zr}$ & NR & NR \\
\hline $\mathrm{Cu}$ & NR & NR & $\mathrm{NH}_{3}$ & 0.164 & NR \\
\hline $\mathrm{Fe}$ & 0.00528 & 0.337 & $\mathrm{CO}_{3}$ & 11.0 & 59.6 \\
\hline $\mathrm{K}$ & NR & 1.60 & $\mathrm{Cl}$ & 0.212 & 15.0 \\
\hline $\mathrm{Mg}$ & 0.00511 & NR & $\mathrm{NO}_{2}$ & 5.56 & 216 \\
\hline Mn & 1.85E-04 & 0.0464 & $\mathrm{PO}_{4}$ & 0.595 & 53.3 \\
\hline $\mathrm{Na}$ & 22.7 & 152 & $\mathrm{SO}_{4}$ & \begin{tabular}{|l|}
1.50 \\
\end{tabular} & 51.2 \\
\hline $\mathrm{CN}$ & 0.00236 & NR & TOC & 0.479 & 35.1 \\
\hline $\mathrm{F}$ & 0.552 & 0.364 & -- & -- & $\cdots$ \\
\hline
\end{tabular}

Notes:

MT = metric ton

NR $=$ not reported

'Based on a 1991 tank volume of $4,315 \mathrm{~kL}(1,140 \mathrm{kgal})$ for comparison with HDW only. The current tank volume is $87 \mathrm{~kL}$ ( $23 \mathrm{kgal}$ ).

${ }^{2}$ Agnew et al. (1996) 
Table D2-2. Sampling and Hanford Defined Waste Model Inventory Estimates for Radioactive Components in Double-Shell Tank 241-AP-103. (decayed to January 1,2000 )

\begin{tabular}{|c|c|c|c|c|c|}
\hline 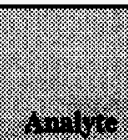 & 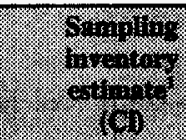 & 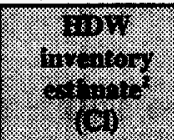 & 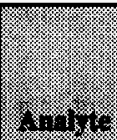 & 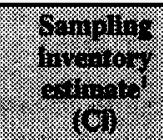 & 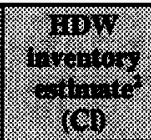 \\
\hline${ }^{241} \mathrm{Am}$ & 0.0488 & -- & ${ }^{2391240} \mathrm{Pu}$ & -- & 55.0 \\
\hline${ }^{14} \mathrm{C}$ & 0.0191 & $\cdots$ & ${ }^{79} \mathrm{Se}$ & 0.0479 & $\mid--$ \\
\hline${ }^{137} \mathrm{Cs}$ & 28,000 & $2.66 \mathrm{E}+05$ & ${ }^{89 / 90} \mathrm{Sr}$ & 11.2 & 57,200 \\
\hline${ }^{60} \mathrm{Co}$ & -- & $\cdots$ & ${ }^{99} \mathrm{Tc}$ & 4.62 & -- \\
\hline${ }^{242} \mathrm{Cm}$ & -- & -- & ${ }^{3} \mathrm{H}$ & 22.4 & -- \\
\hline${ }^{243} \mathrm{Cm}$ & -- & $\cdots$ & -- & $-\cdots$ & -- \\
\hline
\end{tabular}

Notes:

'Based on a 1991 tank volume of $4,315 \mathrm{~kL}(1,140 \mathrm{kgal})$ for comparison with HDW only. The current tank volume is $87 \mathrm{~kL}$ (23 kgal).

${ }^{2}$ Agnew et al. (1996)

Tables D2-1 and D2-2 show that the HDW model estimates are higher for all components except fluoride. In many cases, estimates generated by the model are over one order of magnitude higher than the analytical result. This is true for major and minor components alike. The amount of $\mathrm{Al}$ predicted by the HDW model is over 22 times higher than the analytical result; the estimate for $\mathrm{PO}_{4}$ is almost 90 times higher than the analytical result. Comparisons for sodium and nitrate fare better; the HDW model estimates are higher than the analytical results by factors of 6.7 and 1.4 , respectively.

\section{D3.0 COMPONENT INVENTORY EVALUATION}

Some of the waste mixtures added to tank 241-AP-103 were fairly complex; consequently, any estimate based on transfer information would have a large uncertainty. For example, waste added to the tank often included miscellaneous wastes from $B$ plant and $T$ plant via tank 241-AY-102, for which there are only poorly defined mean compositions.

Except for the high range of values for analyte concentrations in some instances, there is little reason to suspect that the analytical results for tank 241-AP-103 did not accurately reflect the waste's composition when the tank was nearly full. Thus, the mean sample-based inventories from the 1991 grab sample event are considered the best-basis inventory for the small liquid heel remaining. 


\section{D4.0 DEFINE THE BEST BASIS AND ESTABLISH COMPONENT INVENTORIES}

The sampling data should be considered the best basis for the inventory in tank 241-AP-103 for the following reasons:

1. The HDW model predicts concentrations far in excess of both the mean concentrations and upper bounding concentrations reported by the laboratories.

2. No other representative sample data exist, nor is there enough historical or flowsheet information to derive a reliable historical estimate.

3. The existing data indicate adequate precision, and an analysis of variance showed that the waste was not vertically stratified before the bulk of it was pumped out of the tank.

Best-basis inventory estimates for tank 241-AP-103 are presented in Tables D4-1 and D4-2. These estimates are based on reported mean concentration values from the 1991 sampling event and a residual heel volume of $87 \mathrm{~kL}(23 \mathrm{kgal})$. The quality of the estimates has been designated as medium. As mentioned earlier, the sample data suggest that some stratification of the waste may have existed when the tank was nearly full, so that when it was emptied from the bottom, the composition of the remaining heel was commensurate with samples taken from the top of the tank. However, the evidence for this, upon inspection, is inconclusive. This uncertainty forces the quality of the estimate to be medium rather than high. 
HNF-SD-WM-ER-359, Rev. 1

Table D4-1. Best-Basis Inventory Estimates for Nonradioactive Components in Tank 241-AP-103 as of October 21, 1996.

\begin{tabular}{|c|c|c|}
\hline 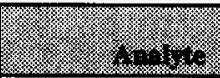 & (2) & $1.2,(3,0, n)$ \\
\hline $\mathrm{Al}$ & 21.5 & S \\
\hline $\mathrm{Bi}$ & NR & \\
\hline $\mathrm{Ca}$ & NR & \\
\hline $\mathrm{Cl}$ & 4.43 & $S$ \\
\hline $\mathrm{CO}_{3}$ & 226 & $S$ \\
\hline $\mathrm{Cr}$ & 0.379 & $S$ \\
\hline $\mathrm{F}$ & 11.7 & \\
\hline $\mathrm{Fe}$ & 0.073 & S \\
\hline $\mathrm{Hg}$ & $<0.00015$ & \\
\hline $\mathbf{K}$ & NR & \\
\hline $\mathrm{La}$ & NR & \\
\hline $\mathrm{Mn}$ & 0.0026 & $S$ \\
\hline $\mathrm{Na}$ & 459 & $S$ \\
\hline $\mathrm{Ni}$ & NR & \\
\hline $\mathrm{NO}_{2}$ & 113 & $S$ \\
\hline $\mathrm{NO}_{3}$ & 355 & $S$ \\
\hline $\mathrm{OH}$ & 132 & $S$ \\
\hline $\mathrm{Pb}$ & $<0.035$ & $S$ \\
\hline $\mathrm{PO}_{4}$ & 12.0 & $S$ \\
\hline $\mathrm{Si}$ & NR & \\
\hline $\mathrm{SO}_{4}$ & 31.5 & $S$ \\
\hline $\mathrm{Sr}$ & NR & $S$ \\
\hline TOC & 9.57 & $S$ \\
\hline $\mathrm{U}$ & 0.32 & $S$ \\
\hline $\mathrm{Zr}$ & NR & \\
\hline
\end{tabular}

Notes:

$$
\begin{aligned}
\text { NR } & =\text { Not reported } \\
{ }^{\text {'S }} & =\text { Sample-based } \\
\text { M } & =\text { Hanford Defined Waste model-based } \\
\mathbf{E} & =\text { Engineering assessment-based }
\end{aligned}
$$

${ }^{2}$ Based on 1991 grab samples (see Appendix B). 
HNF-SD-WM-ER-359, Rev. 1

Table D4-2. Best-Basis Inventory Estimates for Radioactive Components in Tank 241-AP-103 as of October 21, 1996. (2 Sheets)

\begin{tabular}{|c|c|c|}
\hline 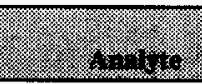 & 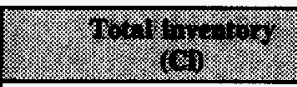 & 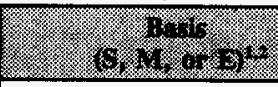 \\
\hline${ }^{3} \mathbf{H}$ & NR & \\
\hline${ }^{14} \mathrm{C}$ & NR & \\
\hline${ }^{59} \mathrm{Ni}$ & NR & \\
\hline${ }^{60} \mathrm{Co}$ & $<0.96$ & $S$ \\
\hline${ }^{63} \mathrm{Ni}$ & NR & \\
\hline${ }^{79} \mathrm{Se}$ & $9.70 \mathrm{E}-04$ & $S$ \\
\hline${ }^{90} \mathrm{Sr}$ & 0.23 & $S$ \\
\hline${ }^{90} \mathrm{Y}$ & NR & \\
\hline${ }^{93} \mathrm{Zr}$ & NR & \\
\hline${ }^{93 \mathrm{~m}} \mathrm{Nb}$ & NR & \\
\hline${ }^{99} \mathrm{Tc}$ & 0.094 & $S$ \\
\hline${ }^{106} \mathrm{Ru}$ & NR & \\
\hline${ }^{113 m} \mathrm{Cd}$ & NR & \\
\hline${ }^{125} \mathrm{Sb}$ & NR & \\
\hline${ }^{126} \mathrm{Sn}$ & NR & \\
\hline${ }^{129} \mathrm{I}$ & NR & \\
\hline${ }^{134} \mathrm{Cs}$ & NR & \\
\hline${ }^{137} \mathrm{Cs}$ & 577 & $S$ \\
\hline${ }^{137 \mathrm{~m}} \mathrm{Ba}$ & NR & \\
\hline${ }^{151} \mathrm{Sm}$ & NR & \\
\hline${ }^{152} \mathrm{Eu}$ & NR & \\
\hline${ }^{154} \mathrm{Eu}$ & $<1.46$ & $S$ \\
\hline${ }^{155} \mathrm{Eu}$ & $<2.31$ & $S$ \\
\hline${ }^{226} \mathrm{Ra}$ & $<21.5$ & $S$ \\
\hline${ }^{227} \mathrm{Ac}$ & NR & \\
\hline${ }^{228} \mathrm{Ra}$ & NR & \\
\hline${ }^{229} \mathrm{Th}$ & NR & \\
\hline${ }^{231} \mathrm{~Pa}$ & NR & \\
\hline${ }^{232} \mathrm{Th}$ & NR & \\
\hline${ }^{232} \mathrm{U}$ & NR & \\
\hline
\end{tabular}


Table D4-2. Best-Basis Inventory Estimates for Radioactive Components in Tank 241-AP-103 as of October 21, 1996. (2 Sheets)

\begin{tabular}{|l|l|l|}
\hline & -10 & \\
\hline${ }^{233} \mathrm{U}$ & NR & \\
\hline${ }^{234} \mathrm{U}$ & $5.70 \mathrm{E}-04$ & $\mathrm{~S}$ \\
\hline${ }^{235} \mathrm{U}$ & $2.95 \mathrm{E}-05$ & $\mathrm{~S}$ \\
\hline${ }^{236} \mathrm{U}$ & NR & \\
\hline${ }^{237} \mathrm{~Np}$ & NR & \\
\hline${ }^{238} \mathrm{Pu}$ & NR & \\
\hline${ }^{238} \mathrm{U}$ & $1.00 \mathrm{E}-04$ & S \\
\hline${ }^{239 / 240} \mathrm{Pu}$ & $<6.06 \mathrm{E}-04$ & S \\
\hline${ }^{241} \mathrm{Am}$ & $9.87 \mathrm{E}-04$ & S \\
\hline${ }^{241} \mathrm{Pu}$ & NR & \\
\hline${ }^{242} \mathrm{Cm}$ & NR & \\
\hline${ }^{242} \mathrm{Pu}$ & NR & \\
\hline${ }^{243} \mathrm{Am}$ & NR & \\
\hline${ }^{243} \mathrm{Cm}$ & NR & \\
\hline${ }^{244} \mathrm{Cm}$ & NR & \\
\hline
\end{tabular}

Notes:

$$
\begin{aligned}
& \mathrm{NR}=\text { Not reported } \\
& \text { 'S }=\text { Sample-based } \\
& \mathrm{M}=\text { Hanford Defined Waste model-based } \\
& \mathrm{E}=\text { Engineering assessment-based }
\end{aligned}
$$

${ }^{2}$ Based on 1991 grab samples (see Appendix B). 


\section{D5.0 REFERENCES}

Agnew, S. F., and J. G. Watkin, 1994, Estimation of Limiting Solubilities for lonic Species in Hanford Waste Tank Supernates, LA-UR-94-3590, Los Alamos National Laboratory, Los Alamos, New Mexico.

Agnew, S. F., 1995, Hanford Defined Wastes: Chemical and Radionuclide Compositions, WHC-SD-WM-TI-632, Rev. 2, (LA-UR-94-2657, Rev. 2), Los Alamos National Laboratory, Los Alamos, New Mexico.

Agnew, S. F., J. Boyer, R. Corbin, T. Duran, J. FitzPatrick, K. Jurgensen, T. Ortiz, and B. Young, 1996, Hanford Tank Chemical and Radionuclide Inventories: HDW Model Rev. 3, LA-UR-96-858, Rev. 0, Los Alamos National Laboratory, Los Alamos, New Mexico.

Hodgson, K. M., M. J., M. D. LeClair, and W. W. Schulz, 1996, Work Plan for Defining a Standard Inventory Estimate for Wastes Stored in Hanford Site Underground Tanks, WHC-SD-WM-WP-311, Rev. 1, Westinghouse Hanford Company, Richland, Washington. 
HNF-SD-WM-ER-359, Rev. 1

\section{APPENDLX E}

\section{BIBLIOGRAPHY FOR TANK 241-AP-103}


HNF-SD-WM-ER-359, Rev. 1

This page left blank intentionally. 


\section{APPENDIX E}

\section{BIBLIOGRAPHY FOR TANK 241-AP-103}

Appendix E provides a bibliography of information that supports the characterization of tank 241-AP-103. This bibliography represents an in-depth literature search of all known information sources that provide sampling, analysis, surveillance, modeling information, and processing occurrences associated with tank 241-AP-103 and its respective waste types.

The references in this bibliography are separated into four broad categories with references contained in subgroups. These categories and their subgroups are listed below. The bibliography is broken down into the appropriate sections of material to use, with an annotation at the end of each reference describing the information source. Where possible, a reference is provided for information sources. A majority of the information listed below may be found in the Tank Characterization Resource Center.

\section{NON-ANALYTICAL DATA}

Ia. Fill History/Waste Transfer Records

Ib. Surveillance/Tank Configuration

Ic. Sample Planning/Tank Prioritization

Id. Data Quality Objectives/Customers of Characterization Data

\section{ANALYTICAL DATA}

IIa. Sampling of Tank Waste and Waste Types

IIb. Sampling of 242-A Evaporator Streams

IIc. Sampling of PUREX Ammonia Scrubber Feed

\section{COMBINED ANALYTICAL/NON-ANALYTICAL DATA}

IIIa. Inventories using both Campaign and Analytical Information IIIb. Compendium of Existing Physical and Chemical Documented Data Sources 


\section{NON-ANALYTICAL DATA}

Ia. Fill History/Waste Transfer Records

Agnew, S.F., R. A. Corbin, T. B. Duran, K. A. Jurgensen, T. P. Ortiz, and B. L. Young, 1996, Waste Status and Transaction Record Summary for the Southeast Quadrant, WHC-SD-WM-TI-689, Rev. 1, Los Alamos National Laboratory, Los Alamos, New Mexico.

- Document contains spreadsheets depicting all available data on tank additions/transfers for SE quadrant.

Le, E. Q., 1994, Process Control Plan for 241-A Evaporator Campaign 94-1, WHC-S-WM-PCP-008, Rev. 1, Westinghouse Hanford Company, Richland, Washington.

- Document contains process control information for the 242-A Evaporator 94-1 campaign.

Mollusky, J. P., 1988, Cladding Removal Waste (CRW) Segregation Routing Status, (internal memorandum 13331-88-645 to D. W. Bergmann, October 24), Westinghouse Hanford Company, Richland, Washington.

- Internal memorandum contains planned transfer information of ammonia scrubber feed into tanks AP-101 and AP-103.

Koreski, G. M., 1991, Operational Waste Volume Projection, WHC-SD-WM-ER-029, Westinghouse Hanford Company, Richland, Washington.

- Document contains spreadsheets depicting all available data on tank additions/transfers from 1981 up to 1991.

Ib. Surveillance/Tank Configuration

Foster, J. L., 1989, Ammonia Releases from Tank Farms, (internal memorandum 13331-89-396 to D. D. Woodrich, October 10), Westinghouse Hanford Company, Richland, Washington.

- Internal memorandum contains locations of anmonia gas on Hanford Site as well as background on the source of the ammonia. 
Harlow, D. G., 1980, Heat Content in 241-AP Tank Farm, (internal letter 65410-80-11 to R. B. Guenther, September 30), Rockwell Hanford Company, Richland, Washington.

- Internal letter contains anticipated heat loads in 241-AP tanks.

Harris, J. P., 1994, Operating Specifications for the 241-AN, AP, AW, AY, AZ, \& SY Tank Farms, OSD-T-151-00007, Rev./Mod. H-8, Westinghouse Hanford Company, Richland, Washington.

- Document contains the operating specifications for the listed double-shell tanks. This includes composition, liquid levels, dome loading, vapor space pressure, etc.

Leach, C. E. and S. M. Stahl, 1993, Hanford Site Tank Farm Facilities Interim Safery Basis Volume $I$ and 11 , WHC-SD-WM-ISB-001, Westinghouse Hanford Company, Richland, Washington.

- Document provides a ready reference to the tank farms safety envelope.

Lipnicki, J., 1995, Waste Tank Risers Available for Sampling, WHC-SD-WM-TI-710, Rev. 1, Westinghouse Hanford Company, Richland, Washington.

- Document gives an assessment of all risers per tank; however, not all tanks are included/completed.

Salazar, B. E., 1994, Double-Shell Underground Waste Storage Tanks Riser Survey, WHC-SD-RE-TI-093, Rev. 4, Westinghouse Hanford Company, Richland, Washington.

- Document shows tank riser locations in relation to tank aerial view as well as a description of riser and its contents.

Tran, T. T., 1993, Thermocouple Status Single-Shell \& Double-Shell Waste Tanks, WHC-SD-WM-TI-553, Rev. 0, Westinghouse Hanford Company, Richland, Washington.

- Document contains information pertaining to thermocouple trees installed in the Hanford Site underground waste tanks. 
Ic. Sample Planning/Tank Prioritization

Bell, K. E., 1994, Tank Waste Remediation System Tank Waste Analysis Plan, WHC-SD-WM-PLN-077, Rev. 0, Westinghouse Hanford Company, Richland, Washington.

- Early version of the characterization planning document.

Brown, T. M., S. J. Eberlein, J. W. Hunt, and T. J. Kunthara, 1996, Tank Waste Characterization Basis, WHC-SD-WM-TA-164, Rev. 2, Westinghouse Hanford Company, Richland, Washington.

- Document that summarizes the technical basis for characterizing the waste in the tanks and assigns a priority number to each tank.

De Lorenzo, D. S., A. T. DiCenso, D. B. Hiller, K. W. Johnson, J. H. Rutherford, D. J. Smith, B. C. Simpson, 1994, Tank Characterization Reference Guide, WHC-SD-WM-TI-648, Rev. 0, Westinghouse Hanford Company, Richland, Washington.

- Summarizes issues surrounding characterization of nuclear wastes stored in Hanford Site waste tanks.

Ecology, EPA and DOE, 1996, Hanford Federal Facility Agreement and Consent Order, as amended, Washington State Department of Ecology, U. S. Environmental Protection Agency, and U.S. Department of Energy, Olympia, Washington.

- Document contains agreement between the U. S. Environmental Protection Agency, U. S. Department of Energy, and Washington State Department of Ecology that sets milestones for completing work on the Hanford Site tank farms.

EPA, 1990, "Identification and Listing of Hazardous Wastes", 40 CFR 261, U.S. Environmental Protection Agency, Washington, D.C.

- Document identifies and lists hazardous wastes, and defines procedures for determining if a waste should be classified as hazardous. 
Grimes, G. W., 1977, Hanford Long-Term Defense High-Level Waste Management Program Waste Sampling and Characterizarion Plan, RHO-CD-137, Rockwell Hanford Operations, Richland, Washington.

- Document contains plan for characterizing waste, short and long term goals, tank priority, analysis needs, estimates of analyte concentrations per waste type, and a characterization flowsheet.

Halgren, D. L., 1991, Double-Shell Tank Waste Analysis Plan, WHC-SD-WM-EV-053, Rev. 1, Westinghouse Hanford Company, Richland, Washington.

- Document outlines the methods for sampling and analysis needed to meet specific data requirements.

Public Law 101-510, 1990, "Safety Measures for Waste Tanks at Hanford Nuclear Reservation," Section 3137 of National Defense Authorization Act for Fiscal Year 1991.

- Document creates the Safety Watch List for the Hanford Site tank farms.

Winters, W. I., L. Jensen, L. M. Sasaki, R. L. Weiss, J. F. Keller, A. J. Schmidt, and M. G. Woodruff, 1989, Waste Characterization Plan for the Hanford Site Single-Shell Tanks, WHC-EP-0210, Westinghouse Hanford Company, Richland, Washington.

- Early version of characterization planning document.

Winkelman, W. D., 1996, Fiscal Year 1994 Tank Waste Analysis Plan, WHC-SD-WM-PLN-120, Rev. 0, Westinghouse Hanford Company, Richland, Washington.

- Document identifies plans and requirements for tanks to be sampled and analyzed and tank characterization reports to be written during FY 1997.

Id. Data Quality Objectives/Customers of Characterization Data

Dukelow, G. T., J. W. Hunt, H. Babad, and J. E. Meacham, 1995, Tank Safety Screening Data Quality Objective, WHC-SD-WM-SP-004, Rev. 2, Westinghouse Hanford Company, Richland, Washington.

- Document contains objectives to sample all tanks for safety concerns (ferrocyanide, organic, flammable gas, and criticality) as well as decision thresholds for energetics, criticality and flammability. 
Von Bargen, B. H., 1995, 242-A Evaporator/Liquid Effluent Retention Facility Data Quality Objectives, WHC-SD-WM-DQO-014, Rev. 1, Westinghouse Hanford Company, Richland, Washington.

- Document contains data needs and requirements for the evaporator program.

\section{ANALYTICAL DATA}

IIa. Sampling of Tank Waste and Waste Types

De Lorenzo, D. S., A. T. DiCenso, D. B. Hiller, L. C. Amato, J. D. Franklin, R. W. Lambie, and B. C. Simpson, 1994, Tank Characterization Report for Double-Shell Tank 241-AP-103, WHC-SD-WM-ER-359, Rev. 0, Westinghouse Hanford Company, Richland, Washington.

- Document summarizes and compares the analytical data for characterization.

Tusler, L. A., 1994, Waste Tank Characterization Sampling Limits, WHC-SD-WM-TI-651, Rev. 0, Westinghouse Hanford Company, Richland, Washington

- Document summarizes and compares the analytical data for operational limits.

Wehner, K. B., 1994, Semivolatile Analytical Results - T734, (internal memorandum to E. Q. Le, May 23), Westinghouse Hanford Company, Richland, Washington.

- Letter contains data results for semivolatile analytes for a mixture of samples from three tanks.

WHC, 1992, Summary Data Report, WHC-SD-WM-DP-025, Addendum 5A Rev. 0 to Addendum 14A Rev. 0, Westinghouse Hanford Company, Richland, Washington.

- Document contains the analytical results from the 1991 sampling of tank 241-AP-103.

WHC, 1992, 222-S Analytical Laboratory 242-A Evaporator Feed Characterization Validation Repor, WHC-SD-WM-DP-025, Addendum 20A Rev. 0, Westinghouse Hanford Company, Richland, Washington.

- Document contains the data validation report for the 1991 grab sampling of tank 241-AP-103. 
IIb. Sampling of 242-A Evaporator Streams

Guthrie, M. D., 1994, 242-A Campaign 94-1 Post Run Document, WHC-SD-WM-PE-053, Rev. 0, Westinghouse Hanford Company, Richland, Washington.

- Document contains results of 242-A Evaporator Campaign 94-1.

Von Bargen, B. H., 1987, 242-A Evaporator Run Schedule for Run 88-1, (internal memorandum 13331-87-975 to G. L. Dunford, December 28), Westinghouse Hanford Company, Richland, Washington.

- Internal memorandum contains 1988 evaporator run planning information.

IIc. PUREX Ammonia Scrubber Feed

Berglund, C. J., 1987, PUREX Ammonia Scrubber Pilot Plant Testing, (internal memorandum 65455-87-082 to K. E. Plummer, September 23), Westinghouse Hanford Company, Richland, Washington.

- Internal memorandum contains information on chemical concentration used as feed to test PUREX Ammonia Scrubber.

Weiss, R. L., and A. L. Prignano, 1987, Report on Ammonia Treatment of PUREX Streams, (internal memorandum 12221-PCL87-035 to Distribution, December 15), Westinghouse Hanford Company, Richland, Washington.

- Internal memorandum contains alternate methods of reducing ammonium concentrations in ammonia scrubber waste streams. 


\section{COMBINED ANALYTICAL/NON-ANALYTICAL DATA}

IIIa. Inventories from Campaign and Analytical Information

Agnew, S. F., J. Boyer, R. A. Corbin, T. B. Duran, J. R. Fitzpatrick, K. A. Jurgensen, T. P. Ortiz, and B. L. Young, 1996, Hanford Tank Chemical and Radionuclide Inventories: HDW Model Rev. 3, LA-UR-96-858, Rev. 0, Los Alamos National Laboratory, Los Alamos, New Mexico.

- Document contains waste type summaries, primary chemical compound/analyte and radionuclide estimates for sludge, supernatant, and solids, as well as supernatant mixing model, tank layer model, and individual tank inventory estimates.

Agnew, S. F., 1995, Letter Report: Strategy for Analytical Data Comparisons to HDW Model, (letter CST-4:95-sfa272 to S. Eberlein, Westinghouse Hanford Company, September 28), Los Alamos National Laboratory, Los Alamos, New Mexico.

- Document contains proposed tank groups based on TLM, and statistical method for comparing analytical information to HDW predictions.

Kupfer, M. J., 1996, Interim Report: Best Basis Total Chemical and Radionuclide Inventories in Hanford Site Tank Waste, WHC-SD-WM-TI-740, Revisions B (Draft) and C (Draft), Westinghouse Hanford Company, Richland, Washington.

- Documents contain a global component inventory for 200 Area waste tanks. Currently, 14 chemical and 2 radionuclide components are inventoried.

Schmittroth, F. A., 1995, Inventories for Low-Level Tank Waste, WHC-SD-WM-RPT-164, Rev. 0, Westinghouse Hanford Company, Richland, Washington.

- Document contains a global inventory based on process knowledge and radioactive decay estimations using ORIGEN2. Pu and $U$ waste contributions are taken at 1 percent of the amount used in processes. Also compares information on Tc-99 from both ORIGEN2 and analytical data. 
IIIb. Compendium of data from other sources physical and chemical

Agnew, S. F., and J. G. Watkin, 1994, Estimation of Limiting Solubilities for Ionic Species in Hanford Waste Tank Supernates, LA-UR-94-3590, Los Alamos National Laboratory, Los Alamos, New Mexico.

- Document gives solubility ranges used for key chemical and radionuclide components based on supernatant sample analyses.

Brevick, C. H., L. A. Gaddis, W. W. Pickett, 1996, Historical Tank Content Estimate for the Southeast Quadrant of the Hanford 200 Areas, WHC-SD-WM-ER-350, Rev. OA, Westinghouse Hanford Company, Richland, Washington.

- Document contains summary information from the supporting document for Tank Farms AN, AP, AW, AY, AZ, and SY as well as in-tank photo collages and the solid (including the interstitial liquid) composite inventory estimates.

Brevick, C. H., L. A. Gaddis, and S. D. Consort, 1995, Supporting Document for the Southeast Quadrant Historical Tank Content Estimate for AP Tank Farm, WHC-SD-WM-ER-315, Rev. 0, Westinghouse Hanford Company, Richland, Washington.

- Supporting document for the Historical Tank Content Estimate spanning WHC-SD-WM-ER-308 to WHC-SD-WM-ER-325. This document contains summary tank farm and tank write-ups on historical data and solid inventory estimates as well as appendices for the data. The appendices contain the following information: App. C - Level History AutoCAD sketch; App. D Temperature Graphs; App. E - Surface Level Graph; App. F, pg F-1 Cascade/Drywell Chart; App. G - Riser Configuration Drawing and Table; App. I - In-Tank Photos; and App. K - Tank Layer Model Bar Chart and Spreadsheet.

Brevick, C.H., L. A. Gaddis, and E. D. Johnson, 1995, Tank Waste Source Term Inventory Validation, Vol I \& II., WHC-SD-WM-ER-400, Rev. 0, Westinghouse Hanford Company, Richland, Washington.

- Document contains a quick reference to sampling information in spreadsheet or graphical form for 23 chemicals and 11 radionuclides for all tanks. 
Hanlon, B. M., 1996, Tank Farm Surveillance and Waste Status Summary Report for Month Ending August 31, 1996, WHC-EP-0182-101, Westinghouse Hanford Company, Richland, Washington.

- These documents contain a monthly summary of: fill volumes, Watch List tanks, occurrences, integrity information, equipment readings, equipment status, tank location, and other miscellaneous tank information. Grouped here are all the monthly summaries from Dec. 1947 - present; however, Hanlon has only authored the monthly summaries from Nov. 1989 to present.

Husa, E. I., R. E. Raymond, R. K. Welty, S. M. Griffith, B. M. Hanlon, R. R. Rios, N. J. Vermeulen, 1993, Hanford Site Waste Storage Tank Information Notebook, WHC-EP-0625, Rev. 0, Westinghouse Hanford Company, Richland, Washington.

- Document contains in-tank photos as well as summaries on the tank description, leak detection system, and tank status.

Husa, E. I., 1995, Hanford Waste Tank Preliminary Dryness Evaluation, WHC-SD-WM-TI-703, Rev 0., Westinghouse Hanford Company, Richland, Washington.

- Document gives assessment of relative dryness between tanks.

Hartley, S. A., G. Chen, C. A. LoPresti, T. M. Ferryman, A. M. Liebetrau, K. M. Remund, S. A. Allen, and B. C. Simpson, 1996, A Comparison of Historical Tank Content Estimate (HTCE) Model, Rev. 3, and Sample-Based Estimates of Hanford Waste Tank Contents, PNL-11429, Pacific Northwest National Laboratory, Richland, Washington.

- Document contains a statistical evaluation of the HDW inventory estimate against analytical values from 12 existing TCR reports using a select component data set.

Remund, K. M., and B. C. Simpson, 1996, Hanford Waste Tank Grouping Study, PNNL-11433, Pacific Northwest National Laboratory, Richland, Washington.

- Document contains a statistical evaluation to group tanks into classes with similar waste properties.

Shelton, L. W., 1995, Chemical and Radionuclide Inventory for Single and Double Shell tanks, (internal memo \#75520-95-007 to R. M. Orme, August 8), Westinghouse Hanford Company, Richland, Washington.

- Memo contains a tank inventory estimate based on analytical information. 
Shelton, L. W., 1995, Radionuclide Inventories for Single and Double Shell Tanks, (internal memo \#71320-95-002 to F. M. Cooney, February 14), Westinghouse Hanford Company, Richland, Washington.

- Memo contains a tank inventory estimate based on analytical information.

Shelton, L. W., 1996, Chemical and Radionuclide Inventory for Single and Double Shell Tanks, (internal memorandum 74A20-96-30 to D. J. Washenfelder, February 28), Westinghouse Hanford Company, Richland, Washington.

- Memo contains a tank inventory estimate based on analytical information.

Van Vleet, R. J., 1993, Radionuclide and Chemical Inventories for the Double-Shell Tanks, WHC-SD-WM-TI-543, Rey. 1, Westinghouse Hanford Company, Richland, Washington.

- Document contains selected sample analysis tables prior to 1993 for double-shell tanks.

WHC, 1993, Process Aids: A Compilation of Technical Letters By Process Laboratories and Technology, WHC-IP-0711-25, Westinghouse Hanford Company, Richland, Washington.

- These documents contain a collection of internal memos and letters concerning tank or process sampling. Grouped here are all of the Process Aids documents from 1969 - 1993. 
THIS PAGE INTENTIONALLY LEFT BLANK 


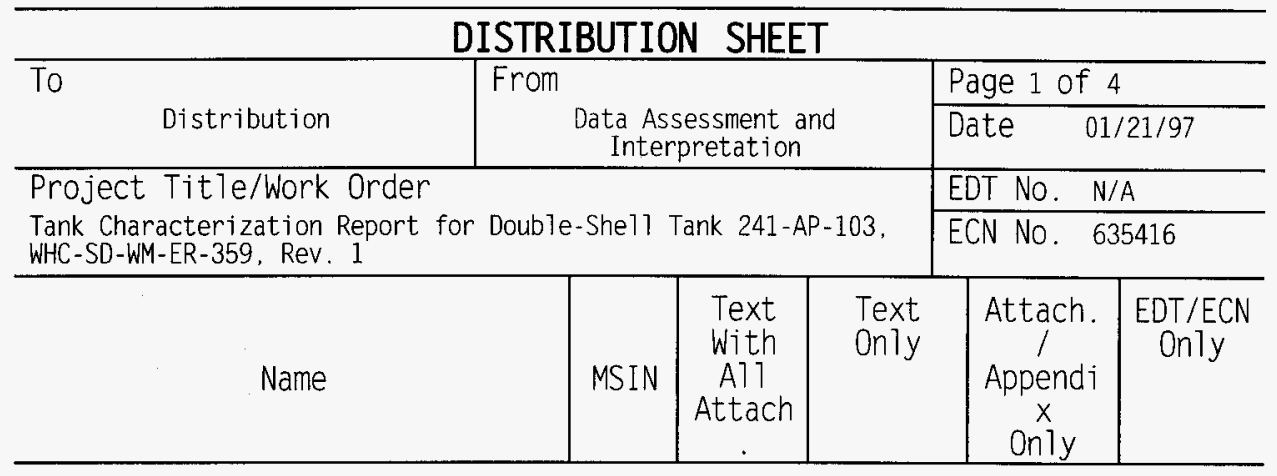

OFFSITE

Sandia National Laboratory

P.0. Box 5800

MS-0744. Dept. 6404

Albuquerque, NM 87815

D. Powers

Nuclear Consulting Services Inc.

P. 0. Box 29151

Columbus, OH 43229-01051

J. L. Kovach

$x$

Chemical Reaction Sub-TAP

P.0. Box 271

Lindsborg, KS 67456

B. C. Hudson

$x$

Tank Characterization Panel

Senior Technical Consultant

Contech

7309 Indian School Road

ATbuquerque, NM 87110

J. Arvisu

$x$

SAIC

20300 Century Boulevard. Suite 200-B

Germantown. MD 20874

H. Sutter

$x$

555 Quince Orchard Rd.. Suite 500

Gaithersburg. MD 20878

P. Szerszen

$x$ 
THIS PAGE INTENTIONALLY LEFT BLANK 


\section{DISTRIBUTION SHEET}

\begin{tabular}{|c|c|c|c|c|c|}
\hline \multirow{2}{*}{ To $\quad$ Distribution } & \multirow{2}{*}{\multicolumn{3}{|c|}{$\begin{array}{l}\text { ata Assessment a } \\
\text { Interpretation }\end{array}$}} & \multicolumn{2}{|l|}{ Page 2 of 4} \\
\hline & & & & \multicolumn{2}{|c|}{ Date $\quad 01 / 21 / 97$} \\
\hline \multirow{2}{*}{\multicolumn{4}{|c|}{$\begin{array}{l}\text { Project Title/Work Order } \\
\text { Tank Characterization Report for Double-She11 Tank 241-AP-103, } \\
\text { WHC-SD-WM-ER-359. Rev. } 1\end{array}$}} & \multicolumn{2}{|c|}{ EDT No. N/A } \\
\hline & & & & \multicolumn{2}{|c|}{ ECN No. 635416} \\
\hline Name & MSIN & $\begin{array}{l}\text { Text } \\
\text { With } \\
\text { Al1 } \\
\text { Attach }\end{array}$ & $\begin{array}{l}\text { Text } \\
\text { Only }\end{array}$ & $\begin{array}{c}\text { Attach. } \\
\text { Appendi } \\
x \\
\text { Only }\end{array}$ & $\begin{array}{l}\text { EDT/ECN } \\
\text { Only }\end{array}$ \\
\hline
\end{tabular}

Los Alamos Laboratory

CST-14 MS-J586

P. O. Box 1663

Los Alamos. NM 87545

S. F. Agnew

$x$

Los Alamos Technical Associates

T. T. Tran

B1-44

$x$

Oqden Environmental

101 East Wellsian Way

Richland, WA 99352

R. J. Anema

$x$

$\mathrm{CH} 2 \mathrm{M} \mathrm{Hill}$

P. 0. Box 91500

Bellevue. WA 98009-2050

M. McAfee

$x$

Tank Advisory Panel

102 Windham Road

Oak Ridge. TN 37830

D. O. Campbe11

$x$

\section{ONSITE}

Department of Energy - Richland 0perations

J. F. Thompson

W. S. Liou

J. A. Poppiti

N. W. Willis $\begin{array}{ll}\text { S7 }-54 & x \\ \text { S7-54 } & x \\ \text { S7-54 } & x \\ \text { S7-54 } & x\end{array}$ 
THIS PAGE INTENTIONALLY LEFT BLANK 


\section{DISTRIBUTION SHEET}

\begin{tabular}{|c|c|c|c|c|c|}
\hline \multirow[b]{2}{*}{ Distribution } & \multirow{2}{*}{\multicolumn{3}{|c|}{$\begin{array}{c}\text { Data Assessment a } \\
\text { Interpretation }\end{array}$}} & \multicolumn{2}{|l|}{ Page 3 of 4} \\
\hline & & & & \multicolumn{2}{|c|}{ Date $\quad 01 / 21 / 97$} \\
\hline \multirow{2}{*}{\multicolumn{4}{|c|}{$\begin{array}{l}\text { Project Title/Work Order } \\
\text { Tank Characterization Report for Double-Shel1 Tank 241-AP-103, } \\
\text { WHC-SD-WM-ER-359. Rev. } 1\end{array}$}} & \multicolumn{2}{|c|}{ EDT No. N/A } \\
\hline & & & & \multicolumn{2}{|c|}{ ECN No. 635416} \\
\hline Name & MSIN & $\begin{array}{l}\text { Text } \\
\text { With } \\
\text { All } \\
\text { Attach }\end{array}$ & $\begin{array}{l}\text { Text } \\
\text { Only }\end{array}$ & $\begin{array}{c}\text { Attach. } \\
/ \\
\text { Appendi } \\
x \\
\text { Only }\end{array}$ & $\begin{array}{c}\text { EDT/ECN } \\
\text { Only }\end{array}$ \\
\hline
\end{tabular}

DE\&S Hanford, Inc.
W. L. Cowley
G. L. Dunford
G. D. Johnson
J. E. Meacham

$\begin{array}{ll}\text { R2 }-54 & X \\ \text { A2 }-34 & X \\ \text { S7-14 } & X \\ \text { S7-14 } & X\end{array}$
$x$
$x$
$x$
$x$

Fluor Daniel Northwest

J. L. Stroup

S3-09

Lockheed Martin Hanford, Corp.

K. M. Hodgson

T. J. Kelley

N. W. Kirch

L. M. Sasaki

B. C. Simpson

ERC (Environmental Resource Center)

Tank Characterization Resource Center

$\begin{array}{ll}\text { HO-34 } & \text { X } \\ \text { S7-21 } & x \\ \text { R2-11 } & x \\ \text { R2-12 } & x \\ \text { R2-12 } & x \\ \text { R1-51 } & x \\ \text { R2-12 } & 5\end{array}$

Lockheed Martin Services, Inc.

\begin{tabular}{lll}
\hline B. G. Lauzon & R1 -08 & $X$ \\
Central Files & A3-88 & $X$ \\
EDMC & $H 6-08$ & $X$
\end{tabular}

Numatec Hanford Corporation
J. S. Hertzel
H5-61
H5-61
$x$
D. L. Lamberd

Pacific Northwest Laboratory

J. R. Gormsen

A. F. Noonan

K $7-28$

K9-91

$x$

$x$

Rust Federal Services of Hanford, Inc.

C. T. Narquis

T6-16 $\quad x$ 
THIS PAGE INTENTIONALLY LEFT BLANK 


\begin{tabular}{|c|c|c|c|c|c|}
\hline \multicolumn{6}{|c|}{ DISTRIBUTION SHEET } \\
\hline \multirow[t]{2}{*}{ To } & \multirow{2}{*}{\multicolumn{3}{|c|}{ From }} & \multicolumn{2}{|l|}{ Page 4 of 4} \\
\hline & & & & \multicolumn{2}{|c|}{ Date $\quad 01 / 21 / 97$} \\
\hline \multirow{2}{*}{\multicolumn{4}{|c|}{$\begin{array}{l}\text { Project Title/Work Order } \\
\text { Tank Characterization Report for Double-She11 Tank 241-AP-103, } \\
\text { WHC-SD-WM-ER-359. Rev. } 1\end{array}$}} & \multicolumn{2}{|c|}{ EDT No. N/A } \\
\hline & & & & \multicolumn{2}{|c|}{ ECN No. 635416} \\
\hline Name & MSIN & $\begin{array}{l}\text { Text } \\
\text { With } \\
\text { All } \\
\text { Attach }\end{array}$ & $\begin{array}{l}\text { Text } \\
\text { Only }\end{array}$ & $\begin{array}{c}\text { Attach. } \\
/ \\
\text { Appendi } \\
x \\
\text { only }\end{array}$ & $\begin{array}{c}\text { EOT/ECN } \\
\text { Only }\end{array}$ \\
\hline
\end{tabular}

SGN Eurisys Services Corp.

D. B. Engelman

L6-37

$x$ 
$T_{i}$

ITENTION:.' $\ldots$ - T BLANK 